\title{
VISITA TÉCNICA: DISCIPLINA CURRICULAR PARA OS CURSOS DE TURISMO
}

\author{
Marcelo Parreira Veloso
}

Orientadora: Prof ${ }^{a}$ Msc. Sandra Vivacqua Von Tiesenhausen

Monografia apresentada ao Centro de Excelência em Turismo da Universidade de Brasília como requisito para a obtenção do Certificado de Especialista em Docência e Pesquisa. 


\begin{abstract}
UNIVERSIDADE DE BRASÍLIA
Centro de Excelência em Turismo

Curso de Especialização em Docência e Pesquisa em Turismo e Hospitalidade
\end{abstract}

\title{
VISITA TÉCNICA: DISCIPLINA CURRICULAR PARA OS CURSOS DE TURISMO
}

\author{
Marcelo Parreira Veloso
}

Banca Examinadora

Orientadora: Profa Msc. Sandra Vivacqua Von Tiesenhausen

Membro:

Membro:

Brasília, DF, 04 de dezembro de 2003 
Veloso, Marcelo Parreira.

Visita Técnica: disciplina curricular para os cursos de Turismo.

Goiânia - GO, 2003, 139p.

Monografia de Especialização em Pesquisa e Docência em Turismo e Hospitalidade.

1. Visita Técnica

2. Turismo

3. Disciplina curricular 
MARCELO PARREIRA VELOSO

\section{VISITA TÉCNICA: DISCIPLINA CURRICULAR PARA OS CURSOS DE TURISMO}

Comissão Avaliadora

Orientadora: Profa Msc. Sandra Vivacqua Von Tiesenhausen

Membro:

Membro:

Brasília, DF, 04 de dezembro de 2003 
À professora Msc. Sandra Vivacqua Von Tiesenhausen

Meus efusivos agradecimentos, pela satisfação em tê-la como orientadora e incentivadora, tanto pela condução profissional inabalável quanto pela expressão pessoal conduzida com compreensão e paciência, proporcionando tranqüilidade para a construção da monografia. 
Dedico este trabalho, inicialmente, a Deus por me conceder o dom da vida e condições para dar mais um passo no degrau da profissionalização e da pesquisa.

Aos meus familiares, pelo apoio, compreensão e tolerância, principalmente nos momentos de stress pela dedicação incessante à monografia.

Aos meus amigos de Brasília que me acolheram em seus lares com gestos de carinho e sincera amizade. Aos professores que me concederam a alegria de aprender ainda mais sobre turismo e hospitalidade. 
Quando vivemos a autenticidade exigida pela prática de ensinar-aprender participamos de uma experiência total, diretiva, política, ideológica, gnosiológica, pedagógica, estética e ética, em que a boniteza deve achar-se de mãos dadas com a decência e com a seriedade.

(Paulo Freire) 


\section{RESUMO}

O desenvolvimento e o incentivo à pesquisa nos cursos de turismo e hotelaria das Instituições de Ensino Superior (IES) no Brasil são motivos de intensa e continuada discussão. Partindo dessa premissa, construímos este projeto monográfico que tem na sua base o referencial denominado "visita técnica" que é, hoje, utilizada de maneira absurdamente indevida pela maioria das IES, no sentido de encobrir uma situação calamitosa de falta de apoio, organização e ordenamento da pesquisa, seja ela de caráter eminentemente científico, seja pela relação e exigência pedagógica e conteudisticamente curricular. A pesquisa, a partir do entendimento finalístico como resultado científico, ou mediano como instrumento de observação, é que predispõe uma análise mais aprofundada da qualidade existente em cada instituição de ensino superior que possa ter ou tenha, no seu projeto pedagógico e conseqüentemente nos conteúdos curriculares, a "visita técnica" como elemento diferencial, inovador e eficiente. Este projeto tem a finalidade de propor uma discussão sobre o objetivo e missão de cada curso superior de turismo e hotelaria, em relação ao dimensionamento que se dá à "visita técnica" desde a simples menção da mesma no projeto pedagógico para atender as exigências das diretrizes curriculares do Ministério da Educação à sua instituição como disciplina efetivamente curricular. Não se trata de uma proposta meramente incomplexa ou sem sustentabilidade técnica e teórica, mas sim uma firme e incontinenti defesa do respeito à pesquisa, principalmente em prol do docente pela qualidade didática e pedagógica a ser oferecida e consumida e em prol do discente pela qualidade profissional e científica que o mesmo adquirirá.

Palavras-chave: Visita Técnica - Instrumento de Observação - Disciplina Curricular 


\begin{abstract}
The development and the incentive for researches in Tourism and Hospitality Courses in colleges and universities in Brazil are the causes of intense and continue discussion. Starting with this, the monographic project developed that is showing here in basing in the referencial denominated "Technique Visit", wich is, today, used absurdly wrong in most universities, in the sense of encover the real catastrophic situation without help, order and organization in researches, in scientific character, or pedagogic relations and exigencies and curricular conteined. The researcher, considering the final intending with scientific result, or median like an observation instrument, wich need a previous quality deep analisys existent in any college that can have or had, in it pedagogic and curricular project, the "Technique Visit" with a different element, newer and efficient. This project has the finality to propose discussion about the objective and mission of each Turism and Hotelary College Course, related to the dimension that gives to the "Technique Visit", since a simple mension in the pedagogic project to undestanding the curricular lines of direction exigencies of Education Ministery to the institutions like a effectly curricular course. It's not a incomplex propose or without technic and teoric sustentability, but a strong and always complex fight for the research respect, specially for the teacher in the didatic and pedagogic quality to be ofered and consumed by the students in the professional and scientific quality that they will adquire.
\end{abstract}

Keywords: Technique Visit - Observation Instrument - Curricular Course 


\section{SUMÁRIO}

INTRODUÇÃO

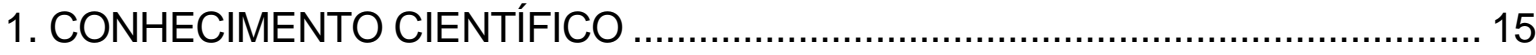

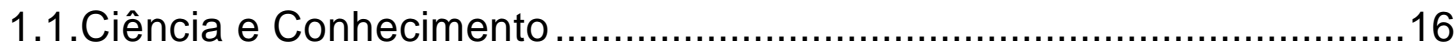

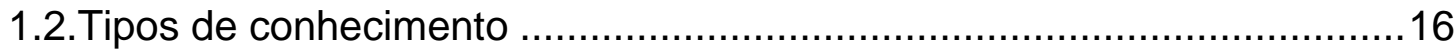

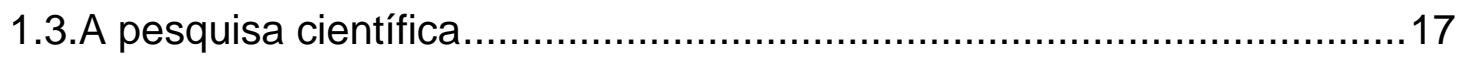

1.3.1. Sustentação conceitual da metodologia .......................................... 19

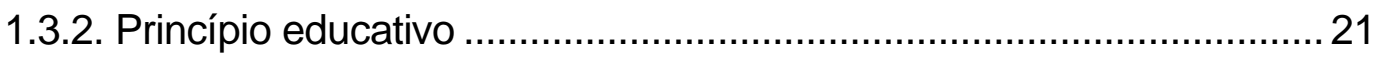

1.3.3. Abordagens: o uso das observações................................................ 24

2.ESTRUTURAÇÃO E DESENVOLVIMENTO DA MONOGRAFIA (Metodologia) ... 29

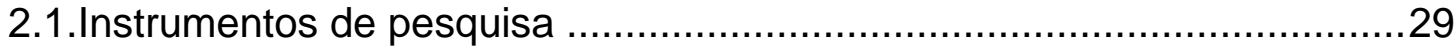

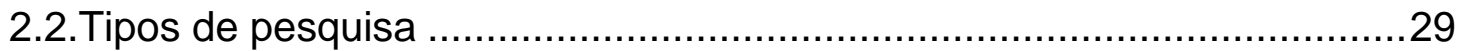

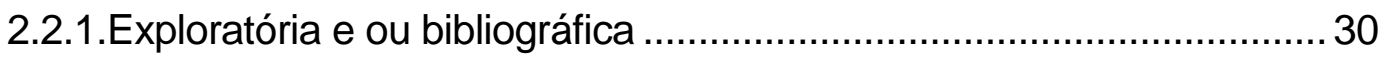

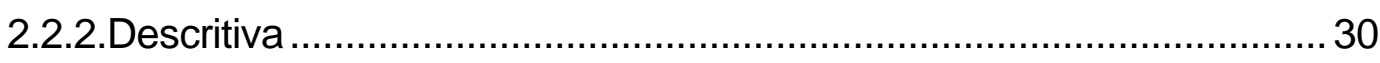

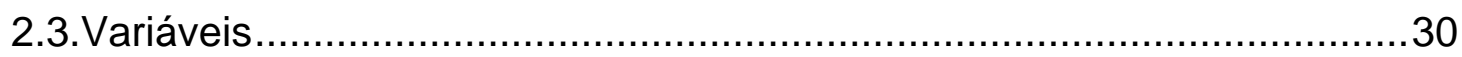

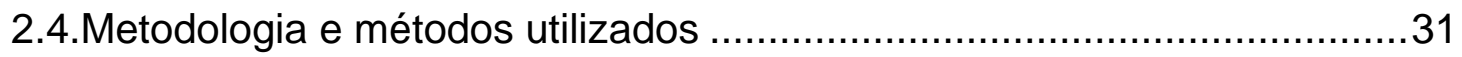

2.4.1.Emissão e recepção de dados e informações .................................... 32

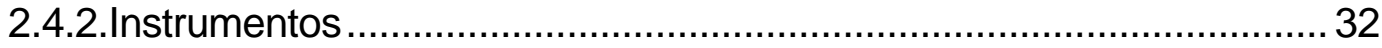

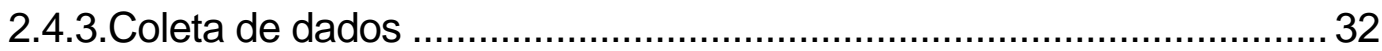

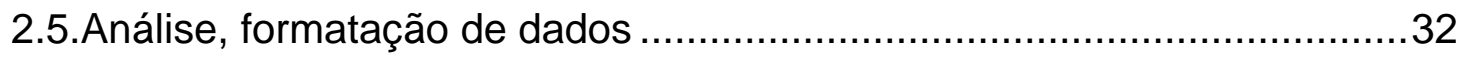

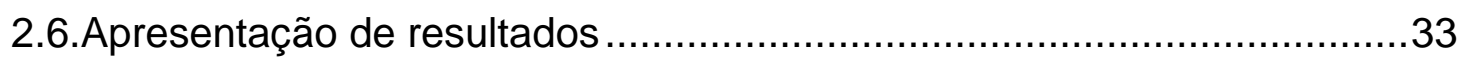

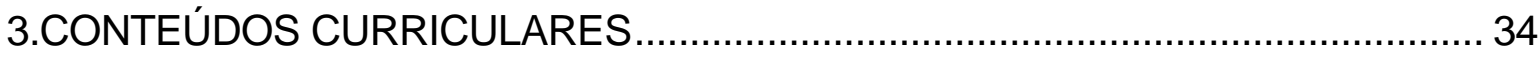

3.1.Diretrizes curriculares - Ministério da Educação.....................................35

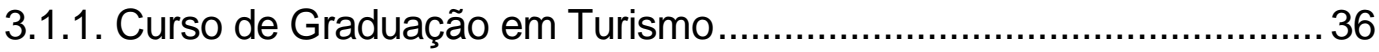

3.2.Instituições de Ensino Superior - Cursos de Turismo e Hotelaria.............39

3.2.1-Ação 1 - Pesquisa às IES através de e-mails...................................... 40

3.2.2-Ação 2 - Pesquisa aos sites das IES ................................................ 51

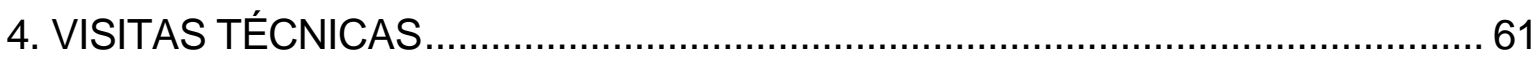

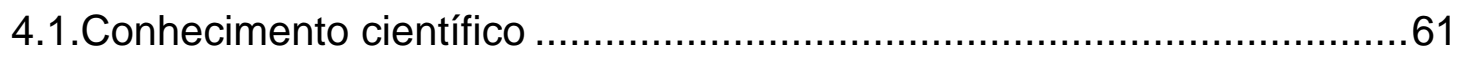

4.2.Similaridade, segmentações turísticas e técnicas de pesquisa ................62 
4.2.1.Pesquisa, o primeiro passo para o entendimento da visita técnica..... 63

4.2.2. Visita técnica: observação sistemática ou pesquisa de campo.......... 64

4.2.3.A visita técnica dentro da visão de investigação científica ................. 67

4.2.4.A visão docente e mercadológica sobre a visita técnica ....................69 69

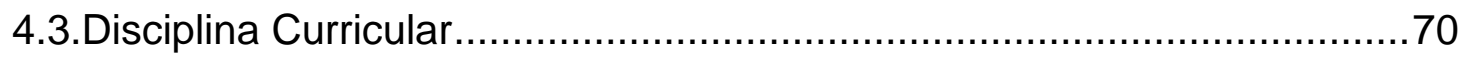

4.3.1-Antecedentes - indicativos de estudo........................................... 70

4.3.2-Justificativa ................................................................................... 71

4.3.3-Condicionantes - fundamentações para análise .............................. 73

4.3.4-Proposta curricular .......................................................................... 75

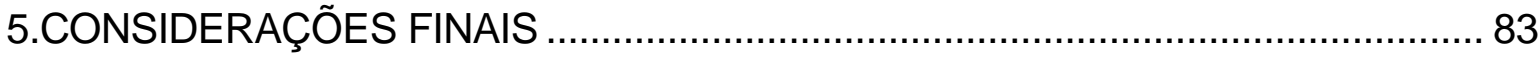

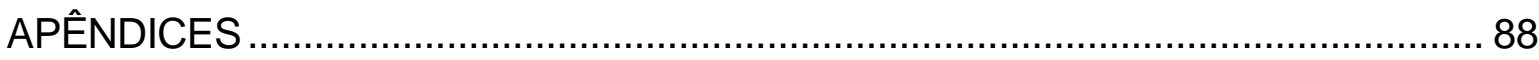

Apêndice A - Artigo: Turismo Acadêmico ............................................89

Apêndice B - Ofício e Questionário às IES ............................................92

Apêndice C - Disciplinas constantes das grades curriculares dos cursos de

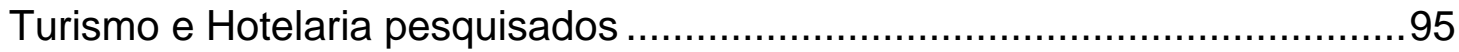

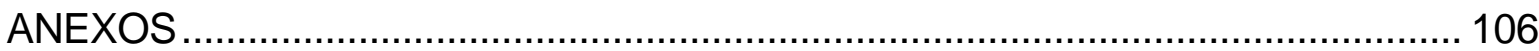

Anexo A - Diretrizes Curriculares do MEC ...........................................107

Anexo B - Sites de busca dos Cursos de Turismo................................. 120

Anexo C - IES que possuem Cursos de Turismo e Hotelaria .....................122

Anexo D - Artigo: A importância das visitas técnicas no curso de turismo e hotelaria. 


\section{Lista de Quadros}

Quadro 1: Dados e informações sobre visita técnica ................................... 43

Quadro 2: Relação da visita técnica com a interdisciplinaridade ........................ 44

Quadro 3: Dados sobre a organização da visita técnica .............................. 45

Quadro 4: Referências bibliográficas utilizadas para a visita técnica..................46

Quadro 5: Considerações sobre a visita técnica ..................................... 47

Quadro 6: Dados sobre a estruturação da visita técnica................................. 48

Quadro 7: Informações e dados sobre a realização e a importância das visita

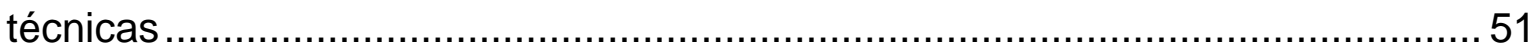

Quadro 8: Instituições de Ensino Superior pesquisadas ................................. 55

Quadro 9: Atividades curriculares de características similares à visita técnica..... 58 Quadro 10: Visita técnica na grade curricular ............................................ 59

Quadro 11: Visitas Técnicas nos cursos de turismo ....................................60 60 


\section{Lista de Tabelas}

Tabela 1: Cursos de Turismo - graduação e ênfases. 


\section{Lista de Gráficos}

Gráfico 1: Respostas das IES aos questionários enviados por e-mail ................ 42

Gráfico 2: Cursos de Turismo - Graduação e ênfases .................................... 51

Gráfico 3: Informações e dados disponibilizados nos sites .............................56 
INTRODUÇÃO

Ensinar - este é o verbo que se conjuga com aprender, conquistar, entender, pesquisar, vivenciar, compreender e, acima de tudo, educar. E é a partir deste verbo que se inicia uma proposta diferenciada para a dinamicidade dos parâmetros curriculares ou projetos pedagógicos dos cursos de turismo e hotelaria (ou hospitalidade) das Instituições de Ensino Superior do Brasil.

Paulo Freire traduz, sabiamente, em seu livro Pedagogia da Autonomia saberes necessários à prática educativa (1996, p.32) que "não há ensino sem pesquisa e pesquisa sem ensino" e complementa, fazendo apologia ao desafio, à busca, em que "ensinar exige risco, aceitação do novo e rejeição a qualquer forma de discriminação" (1996, p.39). Desse modo, parafraseando-o, no sentido de estabelecer a lógica constante nesta proposta monográfica que "ensinar exige reflexão crítica sobre a prática" (1996, p.42), pode-se acentuar que não existe possibilidade, nos dias atuais, de se manter distante o cruzamento da técnica e a prática, da teoria e a prática, em que se visualiza o saber científico, mas se entende, positiva e construtivamente, o senso comum.

Há de se argumentar sobre as condições ou os fundamentos do ensino, a partir de uma proposta inovadora, considerando, como sugere José Carlos Libâneo (1985) que "o ensino propicia a apropriação da cultura e o desenvolvimento do pensamento". Neste sentido, ao propor uma nova interpretação do "ensinar", deve ser computada a articulação existente entre a formação teórica e o princípio prático do discente, ou seja, compatibilizar dois processos que articulam entre si, formando uma unidade, quais sejam:

- o aluno enquanto forma conceitos científicos, incorpora processos de pensamento e vice-versa;

- e quando forma o pensamento teórico, desenvolve ações mentais, buscando a solução de problemas que, evidentemente, suscitam a atividade mental do aluno. 
Assim, pode-se então entender que há uma assimilação por parte do discente com relação ao conhecimento teórico e as capacidades e habilidades relacionadas a esse conhecimento.

Ao projetar a visita técnica para os cursos de turismo como disciplina curricular, há de se compreender não só a formulação metodológica e didática de uma disciplina a ser inserida nos conteúdos curriculares, mas, também, introjetar uma nova forma para a construção do ensino superior, principalmente nos cursos superiores de turismo, hotelaria e hospitalidade.

Todo o desenvolvimento deste trabalho está abastecido com considerações e posicionamentos que foram colhidos, criados, instrumentalizados e positivamente confirmados desde o processo acadêmico, na visão discente até o processo científico, na visão docente. A visita técnica, como disciplina curricular, não é fruto de uma proposta sem balizamento ou apenas para ampliar fluxos (grades) curriculares: tem os seus fundamentos traduzidos pela ingerência literária a ser conduzida aos discentes para o conhecimento e aprimoramento técnico e profissional como também para compor uma integração transdisciplinar, contudo independente, situando os ensinamentos adquiridos em diversas disciplinas e coodificados para uma ação técnica e prática de se vivenciar a realidade produzida pela informação teórica, formal e curricular. 


\section{CONHECIMENTO CIENTÍFICO}

A educação pautada na ciência e na pesquisa é, na atualidade, o argumento mais característico do processo evolutivo, vez que coloca frente a frente a teoria e a prática, enriquecendo as abordagens e as novas conquistas sejam de natureza social, econômica, cultural, histórica, geográfica, política ou ambiental.

Negar a avidez da ciência e do desafio que ela permite utilizar é colocar em desuso a inteligência e o crescimento pessoal e profissional do ser humano, seja em que campo ou área de atuação que ele esteja ou pretenda se estabelecer ou atuar.

As Instituições de Ensino Superior, denominadas academias, têm tido uma atuação considerada tímida, no Brasil, independente da sua classificação social e econômica (pública ou particular) no que tange ao incentivo à pesquisa, à ciência e ao conhecimento científico, preferindo estabelecer projetos pedagógicos, dimensionados pelo Ministério da Educação, que são caracterizados muito mais como "instrumentos para o conhecimento histórico, cultural e científico", sem quase nenhuma interferência na discussão sobre a qualidade da literatura existente.

Desse modo, é importante discutir e ampliar a receita do conhecimento científico, mesmo que através de pequenos trechos que possibilitem aos discentes se interessarem muito mais pelo "desbravamento" do entendimento do que pela "aceitação" do ementário, isto é, sair da posição de estático para a evolução do flexível.

Infere-se, portanto, que o estudo em pauta, tem como ponto de referência o turismo e, dessa maneira, a condução sobre o conhecimento científico será orientada para essa área ou setor. 


\subsection{Ciência e Conhecimento}

De acordo com as inserções dos docentes durante o curso de Especialização em Pesquisa e Docência em Turismo e Hospitalidade da UnB/Cet, e em consonância com as apostilas distribuídas, foram colhidos e catalogados dados e informações que possibilitaram, num primeiro momento, discorrer sobre tais ensinamentos, que é de domínio popular e, portanto, não constituem citações teóricas mas sim argumentos construídos, para que se possa estabelecer parâmetros de análise, principalmente no que tange à importância da ciência e do conhecimento para este trabalho, como poderá ser observado na seqüência.

A ciência vem do latim scire e significa conhecimento ou sabedoria.

O conhecimento é classificado em senso comum, artístico, filosófico, teológico e científico. Vez que o processo em estudo refere-se a dois elementos de real interesse ao ser humano e, em especial, ao seu dinamismo "turístico", serão feitas apresentações sobre o conhecimento do senso comum e o conhecimento científico, numa visão de que esse paralelo pode nortear, com precisão, o entendimento da ação para o turismo.

A base desse entendimento sobre o conhecimento científico, é visualizada a partir dos seguintes aspectos:

- resulta da investigação metódica e sistemática da realidade;

- busca transcender os fatos e fenômenos em si mesmos;

- procura descobrir as causas e leis gerais que os regem;

- trabalha no universo material-físico;

- verificável na prática por experimentação.

\subsection{Tipos de conhecimento}

Os conhecimentos aqui apresentados, de maneira sucinta, são para servir de base para o entendimento sobre a caracterização da visita técnica no contexto do turismo, tomando-se por base os projetos pedagógicos, grades 
curriculares e ementários dos cursos de turismo das Instituições de Ensino Superior no Brasil.

Basicamente, o Conhecimento do senso comum deve ser entendido nos seguintes aspectos:

a) produz informações sobre a realidade;

b) prende-se aos objetivos mais imediatos;

c) não busca descrever os elementos específicos;

d) não se preocupa com a generalidade do conhecimento que se obtém.

Em contrapartida, o Conhecimento Científico, que tem seu surgimento registrado no século XVII, com a constituição histórica da modernidade do ocidente, trilha sobre outros aspectos:

a) não é imediatista;

b) não se contenta com informações superficiais;

c) é crítica - sempre julgando a correção de suas próprias produções;

d) tem como características básicas:

- Procura das possíveis causas de um acontecimento;

- Compreender ou explicar a realidade, apresentando os fatores que determinam a existência de um acontecimento ou evento.

e) tem uma conseqüência política de transformação.

\subsection{A pesquisa científica}

É de real importância a demonstração da pesquisa como produto de referência da execução de uma atividade sobre a característica de uma visita técnica, ou seja, da instrumentalização desta atividade para se chegar ao denominador que é a pesquisa científica.

Alguns dados são importantes de serem traduzidos para este trabalho pois vão, com certeza, demonstrar, com maior clareza, os princípios que norteiam a proposta de se conceber uma disciplina curricular de estruturação 
pedagógica eminentemente integradora da teoria e prática, com fins científicos.

Diante dessas considerações pode-se ousar afirmar que: "pesquisar é construir, edificar, com o conhecimento, uma relação, uma ponte entre a realidade e o sonho".

$\mathrm{E}$ ao estabelecer um entendimento sobre o sonho e a realidade, entre a visão e a ação, é importante desenvolver questionamentos, tais como:

- o que pesquisar?

- porque pesquisar?

- onde pesquisar?

- com quem pesquisar?

- com o que pesquisar?

- quando pesquisar?

- quanto tempo se tem para pesquisar?

A partir destes questionamentos, remete-se ao entendimento de como deve ser e como deve se portar o pesquisador:

- sede de saber;

- iniciativa, autonomia, autoconfiança e otimismo;

- necessidade de autorealização;

- ser e estar envolvido e comprometido;

- exercer o espírito de busca e também a contestação;

- ser sonhador realista;

- calcular, mas saber correr os riscos;

- não temer o fracasso de um resultado;

- ser insistente, obstinado e orientado para o futuro e para resultados;

- cultivar visões, identificar missões e construir cenários.

Transpondo tais características para o propósito deste projeto monográfico, firma-se que o objetivo da pesquisa, como fonte de respostas, deve pairar sobre três indicadores de cunho efetivamente educativo: 
- as circunstâncias institucionais ou profissionais da pesquisa;

- a experiência científica própria ou de outro;

- o estudo e a leitura de grades ou fluxos curriculares.

Assim sendo, os elementos que constituem a formação de uma pesquisa científica têm de ser observados a partir da proposta e do objetivo que se busca, entendendo como tal, a formulação do tema e as premissas ou conteúdos que serão demonstrados. Deve-se entender de maneira objetiva os passos e as circunstâncias preliminares da construção da pesquisa científica.

Serão demonstrados em três partes, os elementos que contribuirão para o entendimento não só da proposta monográfica, mas, também, da possibilidade de sua execução institucional e pedagógica.

\subsubsection{Sustentação conceitual da metodologia}

$\mathrm{Na}$ primeira parte, focaliza-se o tripé da sustentação conceitual da metodologia que considera-se ser exemplarmente "perfeito" para o fomento de um projeto curricular, vez que esta relação de dinâmica grupal exterioriza o sentido da disciplina onde o envolvimento docente e discente estão estreitamente ligados e, positivamente, correlacionados. Esse tripé pode ser observado conforme sugere Filártiga e Tatagiba (2001), compõe-se do Construtivismo, da Teoria de Schutz e dos Métodos Projetivos.

\section{Construtivismo}

É a participação ativa do discente no aprendizado mediante a experimentação, a pesquisa em grupo, o estímulo à dúvida e o desenvolvimento do raciocínio.

Entende-se que é a partir dessa premissa que se pode, envolvidos professores e alunos, encarar o processo e a construção social do conhecimento, aceitando o desafio de produzi-lo, ou seja, vivenciando para aprender, resultando, assim, em conhecimentos partilhados e vivenciados. 
Este método além de envolver docente e discente dentro de uma proposta efetivamente integrativa e participativa, contribui para que se aprenda melhor quem toma parte direta na construção do conhecimento que se adquire.

Por fim, valoriza o intercâmbio e o trabalho desenvolvido em grupo, respeitando a potencialidade de cada um, aproveitando a individualidade para uma maior absorção e enriquecimento do grupo.

\section{Teoria de Schutz}

É a priorização das necessidades interpessoais: inclusão, controle e abertura.

Este método tem como referência o ciclo em que tais necessidades são visualizadas, ou seja, em diversas fases da vida do grupo.

A inclusão é a aceitação, coerente, integrativa e de valorização de cada novo participante do grupo.

O controle é a distribuição compartilhada das responsabilidades de cada membro do grupo. Este é um dos elementos evidenciados na proposta da disciplina e visualizados nos seus antecedentes indicativos de estudo, como poderá ser observado nos capítulos seguintes.

Por fim, a abertura que também pode ser entendida como afeição que é a representação da autenticidade de cada um do grupo, vez que pela sua individualidade percebem-se os vínculos que foram estabelecidos.

\section{Métodos projetivos}

São vistos como técnicas que permitem a investigação dinâmica e holística da personalidade. Este é o ponto crucial para se estabelecer o cooperativismo e o apoio mútuo dos elementos do grupo, principalmente porque o sucesso da ação depende dessa liberdade de dizer e fazer de cada um, a partir do material apresentado e o tipo de atividade proposto. 
Esses métodos são importantes para que se estabeleça o entendimento do que se está diagnosticando de acordo com a leitura do momento atual e do processo em que se encontra, nesse caso, em grupo.

Independente das vantagens e desvantagens que se pode ter com a aplicação desses métodos, é importante salientar que a confirmação da boa aplicabilidade vai depender dos encaminhamentos fornecidos pela instituição para a realização e execução das atividades grupais de caráter prático, principalmente.

\subsubsection{Princípio educativo}

Na segunda parte, de maneira mais ágil e menos condensada, depara-se com o propósito do princípio educativo, que permite estabelecer, com precisão, a relação da visita técnica com a pesquisa a partir da evocação do conhecimento científico com qualidade, formalidade e alto grau de significação política.

Acena-se, portanto, com algumas particularidades que o princípio educativo proporciona, tais como: construção do conhecimento; questionamento científico $X$ questionamento político; formalidade da pesquisa e participação e extensão.

\section{Construção do conhecimento}

Como afirma Demo (2000, p.62), “a pesquisa como princípio educativo aponta para ambiência educativa da escola e da universidade, que faz dos professores tipicamente educadores, além de construtores de conhecimento". Traduzindo para a monografia, esta ação construtiva é que vai permitir estabelecer um grau de relacionamento entre o docente responsável pela disciplina curricular - a visita técnica -, o entendimento da ação didática e metodológica pelo discente refletindo na eficácia da "pesquisa".

Neste ponto, Demo (2000, p.50) reafirma o princípio educativo ao propor que para "construir conhecimento, com qualidade formal e política, significa inovar a realidade, não apenas fazer um texto que estuda teoricamente o que poderia ser realidade". Pode-se dimensionar esta afirmação como a bandeira do projeto 
monográfico, no sentido de quebrar as barreiras e eliminar os entraves que ainda impedem que as disciplinas curriculares deixem de ser meras instâncias estáveis de ensinamento educativo, inibindo a renovação e inovação das ações de caráter didático, principalmente.

\section{Questionamento Científico x Questionamento Político}

Ao focar a pesquisa como princípio educativo, em que se vislumbra o sentido explícito da construção e participação, novamente recorre-se a Demo (2000, p.50) que, como maestria posiciona o questionamento como ferramenta indispensável, "a cidadania começa, inapelavelmente, com o gesto contestatório, com a capacidade de dizer não" e, acrescenta, "o conhecimento inquiridor provoca a inovação", estabelecendo, com certeza, a oportunidade para se produzir conhecimento já que o questionamento científico é tido como a base da construção enquanto o questionamento político é a base da participação.

E é dessa maneira que se estabelece o propósito da disciplinaridade voltada para a pesquisa, para a observação, para a prática (sem perder o foco da técnica e da teoria), pois é sabido que o melhor questionamento é aquele que inova, que faz história, que produz aprendizagem.

Pode-se, também, traduzindo para o campo da argumentação, auferir os seguintes apontamentos:

- questionamento e argumentação são instrumentos de discussão

- a criticidade é um ponto de referência e até de apoio

- a relação pode evidenciar o sujeito e objeto para que se proceda a argumentação a partir da instituição dos dados a serem tratados

- a aceitação dos argumentos sem a retórica pode ser interpretada como adesão ao argumento

- a lógica não é fato em que se constrói a argumentação e até à contraargumentação, mas é indicador de fundamentação para estabelecimento da argumentação 
Isto significa que, bem como os questionamentos, os argumentos devem ser entendidos como elementos de ponderação, discussão, definição e projeção de dados conceitualmente e cientificamente construídos, estudados e efetivamente admitidos como símbolos, representações, fatos, números, atitudes, crenças e comportamentos, tornando-os públicos no sentido de, efetivamente, compartilhar os saberes e construir outros conhecimentos.

\section{Formalidade da pesquisa}

É importante frisar que a pesquisa tem sido tratada de maneira extremamente formal, provocando reações de cunho altamente nocivo ao princípio científico e de conhecimento, inclusive pela desavisada valoração e valorização da sua realização ou até mesmo da estreita empatia à sua execução, ou seja, conforme afirma DEMO:

a pesquisa está cercada de estereótipos, entre eles a idéia de que significa o processo de construção formal de um texto e de dados, exaurindo-se aí a expectativa.(2000,p.48).

\section{Participação e extensão}

O princípio educativo nos leva a discussão sobre dois temas de relevância para o processo de aceitabilidade da visita técnica nos conteúdos curriculares dos cursos superiores de turismo. A participação de discentes e docentes dentro do contexto educativo de orientação pedagógica ainda provoca sérias e intermináveis restrições ao processo de integração para a produção do conhecimento científico, seja pela banalização das discussões seja pelos confrontos de posições e idéias e, até mesmo, pelo corporativismo existente.

De outro lado, também está a extensão que de maneira absolutamente indiferente, conforme DEMO, tem sido "o escamoteamento de uma vida acadêmica distanciada da realidade, improdutiva, alimentada por visível má consciência." (2000, p.64)

Contudo, é importante frisar que a extensão tem de ser absorvida na prática da pesquisa, bem como no conceito, unindo o saber e o mudar, pois não se deve deixar de considerar que a autêntica extensão é prática curricular. 


\subsubsection{Abordagens: o uso das observações}

Na terceira parte são feitas as referências sobre os tipos de abordagens em que se vislumbra as ações que permitem a consecução da visita técnica, tomando-se como deferência à observação sistemática pela distinção que a torna, indubitavelmente, peculiar. Os referenciais dessas abordagens consistem na interpretação dos argumentos e indicadores teóricos constantes, principalmente, no livro Introdução ao projeto de pesquisa científica. (RUDIO, 2002).

Existem três tipos de abordagens estruturadas como "observação" e que, entendidas suas características, complementam os argumentos em que se baseia o objetivo ou finalidade desta monografia, a partir da instrumentalização da visita técnica dentro do contexto da pesquisa científica.

Tais abordagens têm como indicador a prática da atividade em que se configura a visita técnica, a partir da sustentação conceitual metodológica e do princípio educativo já exposto anteriormente.

Antes de adentrar à exposição das abordagens, chama-se a atenção para duas referências importantes de serem inseridas neste trabalho do ponto de vista da argumentação: o experimento e o movimento dialético.

O experimento, é bom frisar, se diferencia da experiência e da observação. Significa que se trata de uma situação criada em laboratório com a finalidade de observar, permeado por um controle, a relação que existe entre fenômenos.

Nesse ponto, é necessário entender que no experimento a observação tem como pressuposto uma variável única, ou seja, é um meio que se utiliza com finalidade de verificar alguma hipótese. Assim, firma-se que o experimento tem certas circunstâncias que devem ser entendidas a partir dos resultados obtidos e que confirma ou não a existência da legitimidade ou da lei científica, ou seja:

- A existência de certas características demonstrando o relacionamento; 
- A persistência da relação independente das variáveis existentes ou até dos valores assumidos.

O segundo referencial é sobre o movimento dialético, ao considerar os três momentos em que se verifica o procedimento, a ação, o envolvimento e, até mesmo, a contradição.

O primeiro momento vislumbra o envolvimento, ou seja, a identidade, a relação de entender a existência e conceber a sua aceitação - uma reação abstrata de "nominar o concreto", o existencial.

O segundo momento é a negação ao aceitar, ou seja, é a proposta da contradição, é a formulação do contraditório pelos argumentos identificados, o conflito de opostos.

O terceiro é a negação da negação, onde se estabelece o contraditório do contraditório, que pode ser entendido como a outra alternativa ou "por outros olhares".

Esses momentos devem ser traduzidos para o processo da dinâmica da visita técnica, onde o que se verifica pode ser o que se propôs, se discutiu e se tomou outra posição - a dialética é a mola propulsora da boa visita técnica, da boa pesquisa de campo, da boa idéia.

A partir desses referenciais, podemos entender qual abordagem é mais ou menos significativa para o comparativo com a visita técnica e para aceitação da mesma como instrumento ou disciplina curricular.

\section{Observação Documental}

Esta observação tem duas vertentes a serem analisadas. De um lado o entendimento de que se refere a apenas a "fatos existentes na realidade empírica" e o "uso aplicável da biblioteca".

Não se deve, portanto, entender que a experiência, a partir da observação documental, com o uso da biblioteca, a pesquisa possa parecer supérflua; ao 
contrário, não há como validar uma pesquisa sem consultar livros e outras obras, de acordo com cada fase do processo.

Desse modo, faz-se necessário revelar que a originalidade de um trabalho, a partir a observação documental, traduz não uma repetição do que outros fizeram, mas sim de que está sendo feito um trabalho diferente do que já existe. Assim, devem ser traçadas algumas linhas de ações para se evitar, inclusive, 0 risco de uma repetição, tais como: delimitação do tema e indicação de cada fase do método a ser utilizado. Esta observação pode, em determinado momento, ser o ponto de partida da construção de uma visita técnica, porém, não única do processo.

\section{Observação Assistemática}

Apesar do entendimento de que esta observação está ligada ao acontecimento que se dá de modo imprevisto, não há, necessariamente que se considerar que tal observação não tenha tido previsão do pesquisador; ao contrário, ela se dá, talvez, não da forma ou no momento que se imaginava ocorrer, mas ela tem legitimidade pelo registro do ocorrido.

A observação assistemática tem o seu entendimento a partir da não formulação dirigida, sistematizada, e até mesmo conceitual, contudo tem uma importante relação entre o momento do pesquisador como participante de um processo e em outro momento como co-participante, ou seja, ele pode ter uma percepção na observação de maneira não agregada, não envolvida.

Se de um lado há visão de que a observação assistemática pode ser superficial pela falta de rigor e de sistematização, de outro lado, verifica-se que o observador-padrão não é aquele que vê e relata o que todos os observadores normais vêem e relatam, mas é aquele que vê em objeto familiares o que ninguém tinha visto antes.

\section{Observação sistemática}

Esta observação é, dentro da expressão do conhecimento científico ou da pesquisa científica, a melhor referência de verossimilhança ao desenvolvimento 
da visita técnica,se considerarmos alguns motivadores ou delineadores deste processo, quais sejam:

a)planejada, estruturada ou controlada - realiza-se em condições controladas, para se responder a propósitos que foram anteriormente definidas;

b)requer planejamento - além de necessitar de operações específicas para a sua execução, o seu desenvolvimento.

Além dos delineadores elencados, há de se considerar alguns elementos indispensáveis:

- planejar e registrar a observação;

- definir os objetivos da observação a partir do interesse da pesquisa;

- definir e indicar os instrumentos a serem utilizados;

- delinear e definir o campo de observação;

- indicar ou definir o sujeito da observação - o observador.

Estes elementos têm como propósito confirmar a legalidade científica da observação sistemática, pois:

- deve ser planejada para poder mostrar com precisão como deve ser feita, quais os dados devem ser registrados e como registrá-los;

- tem como objetivo buscar, detectar ou obter informações da realidade empírica a fim de estabelecer ou verificar as hipóteses que foram enunciadas para pesquisa.

Ao falar em planejamento, registro e controle, o que se verifica e se espera das ações do observador é a competência para observar e obter os dados com a maior imparcialidade possível, evitando que haja a contaminação das suas opiniões e interpretações.

Desse modo, ao contrário a observação documental e assistemática, só a observação sistemática pode ser usada com técnica científica e pela similaridade ou verossimilhança à visita técnica, desta feita, passa a ser o sinônimo desta 
técnica, para ser viabilizada dentro dos conteúdos curriculares dos projetos pedagógicos dos cursos de graduação em turismo.

Enfim, a técnica denominada observação sistemática, tem suas especificidades e que merecem destaques para fomentar, no capítulo seguinte, o argumento base deste projeto monográfico.

- a observação sistemática pode ser feita de modo direto, aplicando sobre os fenômenos que se deseja observador;

- pode ser feita de modo indireto, utilizando instrumentos para registrar ou medir a informação que deseja obter.

- independente do modo em que se realiza, direto ou indireto, o que se busca é a informação, com ou sem a "interferência", para medir ou registrar a informação que se deseja.

- na mesma linha de atuação, se observam três elementos cruciais para os procedimentos se concretizarem:

a) a população - a ser observada

b) as circunstâncias (observação)

c) o local a ser observado. 


\section{ESTRUTURAÇÃO E DESENVOLVIMENTO DA MONOGRAFIA (Metodologia)}

Todos os "elementos" trabalhados nesta monografia, tiveram por base alguns procedimentos que, de maneira inequívoca, devem ser registrados, no sentido de que estes também sejam considerados de relevância para o entendimento sobre a construção da pesquisa e a defesa inconteste da visita técnica como instrumento disciplinar.

Assim, o projeto de "pesquisa" que balizou a construção deste trabalho será exposto, de maneira sucinta, apresentando alguns indicadores referentes aos procedimentos metodológicos que foram extremamente necessários para que se pudesse conceber tal monografia.

\subsection{Instrumentos de pesquisa}

- questionário junto aos Cursos de Turismo e Hotelaria das IES (via Internet);

- utilização como base referencial para a elaboração de questionamentos, o livro "Visita Técnica - uma investigação acadêmica" e o projeto de graduação "A dinâmica das visitas técnicas nos cursos de turismo e hotelaria das IES de Goiânia";

- realização de pesquisas e consultas às Diretrizes Curriculares do MEC e aos projetos pedagógicos e fluxos (grades) curriculares dos cursos de turismo e hotelaria de diversas IES.

\subsection{Tipos de pesquisa}

Considerando as particularidades em que se estabelece a busca de informações e dados, em que a questão não é o fator quantidade mas o indicador qualidade, foram estabelecidas as pesquisas exploratória, bibliográfica e descritiva, transpondo a lógica da pesquisa documental no conteúdo "explorátorio e ou bibliográfico". 
2.2.1.Exploratória e ou bibliográfica

- levantamento de dados e informações contidos nas Diretrizes Curriculares para os Cursos de Turismo das IES delineadas pelo Ministério da Educação, sobre visita técnica;

- coleta de dados e informações contidos em projetos pedagógicos, ementas e fluxos (grades) curriculares dos Cursos de Turismo e Hotelaria das IES, sobre a atividade denominada visita técnica;

- busca em livros, revistas, artigos que citem ou conceituem a prática da visita técnica como atividade turística ou não;

\subsubsection{Descritiva}

- demonstração, através de dados e informações, conforme documentos fornecidos pelas IES, como é caracterizada a visita técnica dentro dos projetos pedagógicos e das grades (fluxos) curriculares.

\subsection{Variáveis}

- nome da IES, tipo de graduação, cidade, estado, site;

- visitas técnicas realizadas por ano, quantidade de discentes e docentes que participam(ram) da VT e Indicação das cidades mais visitadas;

- estruturação das visitas pelos discentes e docentes;

- custo e tempo médio de cada visita técnica;

- como consta a visita técnica dentro do projeto pedagógico?

- Qual é a proposta interdisciplinar da visita técnica? E quando isto acontece?

- existência de um controle de visitas técnicas através de um programa ou sistema de informação (banco de dados, de vídeos, fotos, relatórios, etc...) 


\subsection{Metodologia e métodos utilizados}

Quando se estabelece o propósito de desenvolver uma pesquisa, um dos aspectos que mais influenciam tanto na construção quanto na execução e nos resultados são a metodologia e os métodos utilizados. Neste sentido, a substancialidade da pesquisa é verificada pela apresentação dos dados que, muitas vezes, são sistematizados de maneira a influenciar algum procedimento ou alguma ação. Portanto, os dados a serem buscados e, também, a serem compilados e formatados devem merece uma atenção rigorosa para que o processo da pesquisa obtenha sucesso e veracidade. Senão vejamos a relação entre a obtenção dos dados, a representação e argumentação:

- dados são representações onde se verificam ou se estabelecem pontos de referência a partir de experiências, símbolos, documentos, textos, sentimento, crenças, etc...;

- a abstração é um dos instrumentos de enriquecimento para a consecução de dados e, evidentemente, para a construção e efetivação da pesquisa, levando aos processos de argumentação;

- a partir da ótica de representação, formaliza, nomina ou simboliza o objeto que até ser aceito é entendido como uma "coisa";

- dados possibilitam, com a argumentação, a defesa da representação do objeto;

- a significação dos dados é intrinsecamente ligada aos atos dos argumentos;

- o empirismo, de certo modo, conduz à idealização do dado como fato a ser argumentado, buscando as aceitações científicas, teóricas ou conceituais;

- os dados escritos possibilitam a expressão do entendimento da argumentação e da contra-argumentação, a partir da realidade empírica e do sistema simbólico;

- os estudos das organizações, a partir da utilização de dados escritos, em particular, permitem a inserção e recepção de informações que se transformam em fatos demonstrativos que revelam as relações existentes entre a causa, o efeito e os fins que se resultam; 
- os dados podem ser entendidos a partir da experimentação (ação e reação), da manipulação de informações (causa e efeito), o que significa a mensuração de dados ou a representação das relações em que se identificam os mesmos;

- os dados, a partir de estudos de caráter metodológico, fornecem informações e representações em que são pré-estabelecidos os argumentos para a sua conclusão ou apresentação, com a finalidade própria de demonstrar ou explicar posições, conceitos ou teorias.

\subsubsection{Emissão e recepção de dados e informações}

- pesquisa (entrevista - questionário) enviada por e-mail às IES;

- coleta de documentos, dados e informações, sobre visita técnica, junto às IES através dos sites das mesmas;

\subsubsection{Instrumentos}

- foram utilizados questionários e ficha de coleta de dados e informações;

- questionários foram confeccionados de acordo com as variáveis expostas neste projeto, com perguntas abertas;

\subsubsection{Coleta de dados}

- pesquisador: coleta de dados feita pelo próprio autor da monografia;

2.5.Análise, formatação de dados

- pasta/arquivo: desenvolvimento dentro de programas para acondicionar dados e informações ( excel, word, power point.);

- tabulação: Questões abertas, Informações e dados de caráter empírico; 
- cruzamentos: Dados e informações constantes nos fluxos (grades) curriculares/projetos pedagógicos; Disciplinas constantes nos fluxos (grades) curriculares do $1^{\circ}$ ao $4^{\circ}$ ano.

2.6.Apresentação de resultados

- quadros, gráficos, tabelas e dados estatísticos;

- apresentação escrita e eletrônica (exigência monográfica). 


\section{CONTEÚDOS CURRICULARES}

Ao suscitar o processo de discussão sobre os conteúdos curriculares dos cursos de turismo é de suma importância entender, mesmo que de maneira breve, quais são as finalidades das instituições de ensino superior em conformidade com a Lei de Diretrizes Bases da Educação-LDB/96 (Lei 9.394/96 de dezembro de 1996):

- estimular a criação cultural e o desenvolvimento do espírito científico e do pensamento reflexivo;

- incentivar o trabalho de pesquisa e a investigação científica, propiciando ações que permitam o desenvolvimento da ciência e da tecnologia, bem como da criação e difusão da cultura, tendo como meta desenvolver o entendimento do homem e do meio em que vive;

- possibilitar a formação de diplomados em diferentes áreas de conhecimento, preparando-os para a inserção em setores profissionais e para participar no desenvolvimento da sociedade brasileira e colaborando com a sua formação contínua;

- promover a divulgação de conhecimentos culturais, científicos e técnicos que constituem patrimônio da humanidade e comunicar o saber através do ensino, de publicações ou de outras formas de comunicação;

- fomentar o aperfeiçoamento cultural e profissional e possibilitar a correspondente concretização, integrando os conhecimentos adquiridos a partir da estrutura intelectual sistematizadora do conhecimento de cada geração;

- incentivar e estimular o conhecimento dos problemas do mundo presente,, principalmente àqueles de caráter regional e nacional, no sentido de prestar serviços especializados à comunidade, estabelecendo assim uma relação de reciprocidade;

- estabelecer mecanismos para promover a extensão, com vistas à participação da população, tendo como base a difusão das conquistas e benefícios resultantes da criação cultural e da pesquisa científica e tecnológica geradas na instituição. 
Dessa maneira, o que se vislumbra é a definição clara da responsabilidade da educação superior sobre a preparação do indivíduo para a inserção profissional e, conseqüentemente, a sua participação no desenvolvimento da sociedade brasileira e, também, incentivando-o para o trabalho de pesquisa e de investigação científica, com fins de produção do conhecimento científico.

\subsection{Diretrizes curriculares - Ministério da Educação}

Alguns parâmetros das Diretrizes Curriculares - Lei 9.394/96 de dezembro de 1996 - LDB/96 (Vide Anexo A) devem ser analisados de forma a entender como são desenvolvidos as atividades complementares, as pesquisas de campo e os estágios, norteadores da discussão sobre a viabilidade da "visita técnica" se transformar em disciplina curricular.

Desse modo, importa registrar alguns dados constantes nas diretrizes curriculares, tais como:

Currículo mínimo - uniformidade - responsabilidade de todas as IES;

Flexibilidade e qualidade - formação oferecida aos estudantes;

Composição de carga horária - liberdade para ser estabelecida pelas IES, obedecendo à integralização dos currículos;

Indicação de tópicos e campos de estudo - ensino aprendizagem evitando-se a fixação de conteúdos específicos com cargas horárias prédeterminadas;

Formação profissional - solidez e habilitações - através de produção de conhecimento qualificado;

Prática de estudos independentes - progressiva autonomia dos estudantes;

Ambiente extra-escolar - reconhecimento de habilidades, conhecimentos e competências adquiridas pelos discentes;

Teoria e prática - fortalecimento na articulação - valorizando a pesquisa individual e coletiva, seja em estágios, atividades de extensão - incluindo como parte nas cargas horárias; 
Avaliações periódicas - incluir orientações para a condução - utilizando instrumentos variados e que sirvam para informar a docentes e discentes a cerca do desenvolvimento das atividades didáticas.

Estágio Curricular - Supervisionado - deve ser concedido como conteúdo curricular implementador do perfil do formando - consistindo numa atividade obrigatória, mas diversificada, visando a consolidação prévia dos desempenhos profissionais desejados, observadas as peculiaridades de cada curso de graduação.

Atividades Complementares - este, hoje, tem sido o indicador da concepção da visita técnica, pela relação absoluta das características em que se fundamenta, tais como:

a) possibilita o reconhecimento, por avaliação, de habilidades e competências do aluno, inclusive adquiridas fora do ambiente escolar;

b) amplia o currículo com experimentos e vivências acadêmicos, internos ou externos ao curso;

c) orienta e estimula a prática de estudos independentes, transversais, opcionais, de interdisciplinaridade, de permanente e contextualizada atualização profissional específica, sobretudo nas relações com o mundo do trabalho, estabelecidas ao longo do curso, notadamente integrando-as às diversas peculiaridades regionais e culturais;

d) Inclusão de projetos de pesquisa, monitoria, iniciação científica, projetos de extensão, módulos temáticos, seminários, simpósios, congressos, conferências, de forma interdisciplinar, integrada como demais conteúdos realizados.

\subsubsection{Curso de Graduação em Turismo}

As diretrizes curriculares delineiam o perfil do formando em turismo, das suas competências e habilidades e dos conteúdos curriculares necessários para os cursos de turismo conforme definição constante no Parecer CNE/CES 776/97. Não se quer, evidentemente, neste trabalho, analisar de maneira exaustiva as orientações constantes nessas diretrizes, mas sim, utilizar as referências constantes nela, no sentido de propor uma inovação em seus conteúdos curriculares. 
A partir das condições em que se situam os cursos de graduação no Brasil, é que se pode entender qual a necessidade de se renovar, inovar e modificar alguns modos de atuação pedagógica dos parâmetros curriculares, pois são perceptíveis as deficiências didáticas e pedagógicas, principalmente se considerarmos que os dias de hoje, conforme afirma BRAGA:

a graduação é apenas uma formação de "partida". Além dos desenvolvimentos de experiência e dos estudos pessoais, qualquer profissional é freqüentemente solicitado a retomar estudos e cursos, fazer reimersões nos processos formadores para atualização e aprofundamento. Os conhecimentos, de certa forma, precisam ser substituídos" ou pelo menos revistos. (2001, p.108).

\section{Perfil Desejado do Formando}

Oportunizar a formação de um profissional apto a atuar em mercados altamente competitivos e em constante transformação, cujas opções possuem um impacto profundo na vida social, econômica e no meio ambiente, exigindo uma formação ao mesmo tempo generalista, no sentido tanto do conhecimento geral, das ciências humanas, sociais, políticas e econômicas, como também de uma formação especializada, constituída de conhecimentos específicos, sobretudo nas áreas culturais, históricas, ambientais, antropológicas, de Inventário do Patrimônio Histórico e Cultural, bem como o agenciamento, organização e gerenciamento de eventos e a administração do fluxo turístico.

\section{Competências e habilidades}

Possibilitar formação profissional que revele, pelo menos, as seguintes competências e habilidades:

a) compreensão das políticas nacionais e regionais sobre turismo;

b) utilização de metodologia adequada para o planejamento das ações turísticas, abrangendo projetos, planos e programas, com os eventos locais, regionais, nacionais e internacionais;

c) positiva contribuição na elaboração dos planos municipais e estaduais de turismo;

d) domínio das técnicas indispensáveis ao planejamento e à operacionalização do Inventário Turístico, detectando áreas de novos negócios e de novos campos turísticos e de permutas culturais; 
e) domínio e técnicas de planejamento e operacionalização de estudos de viabilidade econômico-financeira para os empreendimentos e projetos turísticos;

f) adequada aplicação da legislação pertinente;

g) planejamento e execução de projetos e programas estratégicos relacionados com empreendimentos turísticos e seu gerenciamento;

h) intervenção positiva no mercado turístico com sua inserção em espaços novos, emergentes ou inventariados;

i) classificação, sobre critérios prévios e adequados, de estabelecimentos prestadores de serviços turísticos, incluindo meios de hospedagens, transportadoras, agências de turismo, empresas promotoras de eventos e de outras áreas, postas com segurança à disposição do mercado turístico e de sua expansão;

j) domínio de técnicas relacionadas com a seleção e avaliação de informações geográficas, históricas, artísticas, esportivas, recreativas e de entretenimento, folclóricas, artesanais, gastronômicas, religiosas, políticas e outros traços culturais, como diversas formas de manifestação da comunidade humana;

k) domínio de métodos e técnicas indispensáveis ao estudo dos diferentes mercados turísticos, identificando os prioritários, inclusive para efeito de oferta adequada a cada perfil do turista;

l) comunicação interpessoal, intercultural e expressão correta e precisa sobre aspectos técnicos específicos e da interpretação da realidade das organizações e dos traços culturais de cada comunidade ou segmento social;

m) utilização de recursos turísticos como forma de educar, orientar, assessorar, planejar e administrar a satisfação das necessidades dos turistas e das empresas, instituições públicas ou privadas, e dos demais segmentos populacionais;

n) domínio de diferentes idiomas que ensejem a satisfação do turista em sua intervenção nos traços culturais de uma comunidade ainda não conhecida;

o) habilidade no manejo com a informática e com outros recursos tecnológicos;

p) integração nas ações de equipes interdisciplinares e multidisciplinares interagindo criativamente nos diferentes contextos organizacionais e sociais; 
q) compreensão da complexidade do mundo globalizado e das sociedades pós-industriais, onde os setores de turismo e entretenimento encontram ambientes propícios para se desenvolverem;

r) profunda vivência e conhecimento das relações humanas, de relações públicas, das articulações interpessoais, com posturas estratégicas para o êxito de qualquer evento turístico;

s) conhecimentos específicos e adequado desempenho técnicoprofissional, com humanismo, simplicidade, segurança, empatia e ética.

\section{Conteúdos Curriculares}

Os cursos de graduação em Turismo deverão contemplar, em seus projetos pedagógicos e em sua organização curricular, conteúdos que atendam aos seguintes eixos interligados de formação:

a) Conteúdos Básicos: estudos relacionados com os aspectos Sociológicos, Antropológicos, Históricos, Filosóficos, Geográficos, Culturais e Artísticos, que conformam as sociedades e suas diferentes culturas;

b) Conteúdos Específicos: estudos relacionados com a Teoria Geral do Turismo, Teoria da Informação e da Comunicação, estabelecendo ainda as relações do Turismo com a Administração, o Direito, a Economia, a Estatística e a Contabilidade, além do domínio de, pelo menos, uma língua estrangeira;

c) Conteúdos Teórico-Práticos: estudos localizados nos respectivos espaços de fluxo turístico, compreendendo visitas técnicas, inventário turístico, laboratórios de aprendizagem e de estágios.

\subsection{Instituições de Ensino Superior - Cursos de Turismo e Hotelaria}

A realidade percebida sobre a visita técnica do "ponto de vista" disciplinar, empreendida pelos cursos de turismo das Instituições de Ensino Superior do Brasil, será analisada sobre dois aspectos, dentro desta estrutura monográfica, como relevantes para determinar os argumentos em que se baseia a proposta constante no projeto. 
O aspecto inicial refere-se às dificuldades na coleta de informações e dados junto às instituições, vez que os indicadores constantes nos sites, forçosamente, prejudicam e limitam a acessibilidade mais direta e ágil da busca empreendida.

Além do reduzido número de sites que disponibilizam a relação geral dos cursos de turismo, os dados e endereços das instituições constantes nos mesmos, principalmente os e-mails, na sua maioria estão em desuso ou já foram substituídos por outros, inviabilizando o acesso às informações para a catalogação dos dados para a pesquisa proposta.

O segundo aspecto diz respeito ao atendimento proporcionado pelas instituições contactadas ou que receberam a solicitação de informações e dados elencados em questionário e requerida por e-mail.

Neste aspecto pode-se visualizar uma proporção pequena, mas suficientemente produtiva, tendo em vista 0 interesse dispensado pelos responsáveis pelos cursos de turismo, numa clara demonstração do alto grau de profissionalismo e respeito à dedicação ao estudo científico.

Assim, o que será demonstrado faz parte dos argumentos em que se baseia a proposta de viabilizar a visita técnica como disciplina curricular.

Para o entendimento desses aspectos, desenvolvemos a apresentação através de ações classificadas de Ação 1 que se refere à pesquisa às Instituições de Ensino Superior-IES através de e-mails com a aplicação de um questionário e a Ação 2 que se refere à pesquisa aos sites das IES.

\subsection{1-Ação 1 - Pesquisa às IES através de e-mails}

Foi desenvolvido um questionário acompanhado de ofício (Apêndice B) com base nos referenciais do projeto de pesquisa, em que se buscava detectar alguns dados e procedimentos, tais como: 
a)catalogar as IES de acordo com os dados constantes em sites (Internet), vide Ministério do Turismo, ABBTUR, Turismologia e Canaltur (Anexo B). Foram selecionadas diversas IES, de todos os estados brasileiros, considerando os e-mails existentes nos referidos sites;

b)enviar o questionário às IES através dos e-mails catalogados e selecionados;

c)repetir o envio após 30 (trinta) dias;

d)formatar todos os dados colhidos/respondidos;

e)verificar o grau de interesse das IES em responder ao questionário, bem como detectar sobre os dados corretos dos e-mails;

f)de acordo com o grau de interesse das IES em responder o questionário, elaborar planilhas e gráficos no sentido de apresentar o diagnóstico dos argumentos e respostas concedidos.

Assim sendo, procedeu-se a catalogação de 120 IES e foi enviado o questionário. Após 35 (trinta e cinco) dias foi enviado o questionário (via e-mail) para 60 IES das que já tinham sido enviadas. O resultado desse trabalho foi:

1)dos 120 questionários enviados obteve-se as respostas de apenas 5 IES que responderam ao questionário;

2)dos 120 e-mails enviados na primeira vez e dos 60 na segunda vez, 89 retornaram sem concretizar o envio, constando observações de que "não havia confirmado o recebimento" ou "não foi concluído o envio".

3)dos 31 restantes, obteve-se as seguintes respostas: (Vide Gráfico 1)

a) 03 IES não tinham como responder pois estavam em fase inicial do curso;

b) 05 IES informaram que enviariam posteriormente;

c) 02 IES alegaram que não tinha como responder;

d) 03 IES informaram que tinham encaminhado à Coordenação do Curso;

e) 05 IES responderam e solicitaram que enviassem o resultado quando da monografia;

f) 02 IES retornaram o e-mail solicitando um prazo para enviarem a resposta ao questionário, houve a concordância em ampliar o prazo, apesar do pequeno espaço que tería-se para a tabulação dos dados, contudo não enviaram;

g) 11 IES não se manifestaram. 
Dessa maneira foram estruturados os quadros dos e-mails respondidos, tomando-se por base as referências apresentadas pelas IES, classificando como elementos norteadores da proposta da monografia;

Após a definição dos procedimentos, passou-se então à demonstração do primeiro ponto que é sobre as bases referenciais apresentadas pelas IES de acordo com os questionamentos formulados:

Gráfico 1: Respostas das IES aos questionários enviados por e-mail
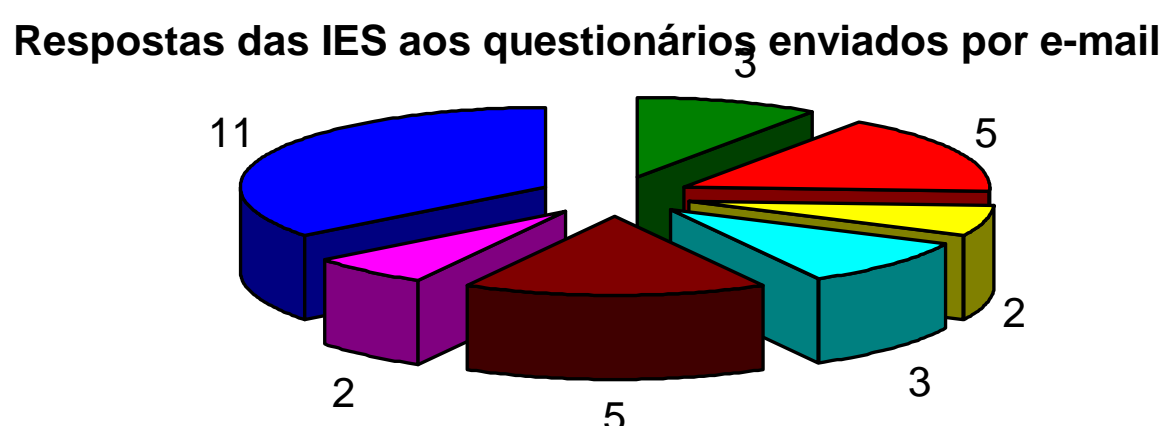

Não tinham como responder pois estavam em fase inicial do curso;

口Informaram que enviariam posteriormente;

$\square$ Alegaram que não tinha como responder;

口Informaram que tinham encaminhado à Coordenação do Curso;

Responderam e solicitaram que enviassem o resultado quando da monografia;

Retornaram o e-mail solicitando um prazo para enviarem a resposta ao questionário, concordamos em ampliar o prazo, apesar do pequeno espaço que teríamos para a tabulação dos dados, contudo não enviaram;

Não se manifestaram.

Os comentários sobre as respostas cedidas pelas instituições serão de referência breve, vez que as mesmas foram "agradavelmente" expressas dentro de um entendimento que por si só estabelece a relação comparativa aos argumentos apontados anteriormente e que serão realimentados no capítulo seguinte quando será detalhada de maneira efetiva a proposta e objetivo do projeto monográfico. 
$1^{a}$ Questão - Dados e informações do projeto pedagógico e da grade curricular do curso de turismo e hotelaria sobre visita técnica (pesquisa ou observação sistemática).

Esta questão buscava identificar a inserção da visita técnica nos projetos pedagógicos dos cursos de turismo das instituições.

Como pode ser percebida no Quadro 1, a visita técnica tem alguns pontos que evoca a sua inserção quase que "obrigatória", contudo não se verifica a exigência clara de que seja inserida como disciplina curricular. Chama a atenção uma das informações cedidas pelas instituições que, nesse caso, tem a sua manifestação privilegiada pela similaridade com os argumentos buscados no sentido de "demonstrar" a viabilidade da visita técnica ser inserida como disciplina curricular, qual seja:

No projeto pedagógico do curso, a questão das visitas técnicas são obrigatórias, através de uma proposta de interdisciplinaridade. Para tanto, foi criada a disciplina "Práticas Orientadas" do $1^{\circ}$ ao $6^{\circ}$ semestre.(Faculdade Cambury/Formosa-GO)

Quadro 1: Dados e informações sobre visita técnica

\begin{tabular}{|c|c|}
\hline INSTITUIÇÃO & $\begin{array}{c}\text { 1.Dados e informações do projeto pedagógico e da grade curricular do } \\
\text { curso de turismo e hotelaria sobre visita técnica (pesquisa ou } \\
\text { observação sistemática) }\end{array}$ \\
\hline $\begin{array}{l}\text { Faculdade } \\
\text { Cambury } \\
\text { (Formosa/GO) }\end{array}$ & $\begin{array}{l}\text { No projeto pedagógico do curso, a questão das visitas técnicas são } \\
\text { obrigatórias, através de uma proposta de interdisciplinaridade. Para tanto, foi } \\
\text { criada a disciplina "Práticas Orientadas" do } 1^{\circ} \text { ao } 6^{\circ} \text { semestre. }\end{array}$ \\
\hline $\begin{array}{l}\text { Centro de } \\
\text { Educação São } \\
\text { José }\end{array}$ & $\begin{array}{c}\text { Todas as disciplinas podem realizar visitas técnicas atendendo as } \\
\text { necessidades das ementas. }\end{array}$ \\
\hline $\begin{array}{l}\text { Faculdade } \\
\text { Metropolitana de } \\
\text { Curitiba/PR }\end{array}$ & $\begin{array}{l}\text { Inserida nas atividades complementares e nas atividades de cada disciplina. } \\
\text { Observação sistemática verificada por relatórios. }\end{array}$ \\
\hline $\begin{array}{l}\text { Faculdade } \\
\text { CECAP } \\
\text { (Brasília/DF) }\end{array}$ & $\begin{array}{l}\text { As visitas técnicas são articuladas com os conteúdos de diferentes } \\
\text { disciplinas. Por exemplo: Alimentos e bebidas - os alunos visitam } \\
\text { restaurantes e analisam o preparo dos alimentos. }\end{array}$ \\
\hline $\begin{array}{c}\text { Universidade São } \\
\text { Marcos } \\
\text { (São Paulo/SP) }\end{array}$ & Ver grade anexa (contudo não foi enviada) \\
\hline
\end{tabular}

$2^{a}$ Questão - Qual a relação da visita técnica com a interdisciplinaridade? Se existem instrumentos didáticos e metodológicos que permitem estabelecer essa relação?

$\mathrm{Na}$ questão 2, os pontos citados sobre a relação da visita técnica com a interdisciplinaridade (Vide Quadro 2), demonstram claramente que a produção 
curricular executada com os tópicos ou disciplinas integradas fortalece os propósitos dos cursos e, seguramente, implementa uma "voracidade acadêmica positiva" no conceito científico e profissional do turismo, ou seja, proporciona ao discente, juntamente com o docente e a instituição, uma relação de entendimento qualificativo e até quantitativo da produção científica, política, social e educacional, robustecendo o conceito não só do graduando junto ao mercado ou às instituições e entidades voltadas para o turismo, mas também do docente e do próprio curso da instituição de ensino superior.

Quadro 2: Relação da visita técnica com a interdisciplinaridade

\begin{tabular}{|c|c|}
\hline INSTITUIÇÃO & $\begin{array}{c}\text { 2.Qual é a relação da visita técnica com a interdisciplinaridade? } \\
\text { Se existem instrumentos didáticos e metodológicos que permitem } \\
\text { estabelecer essa relação? }\end{array}$ \\
\hline $\begin{array}{l}\text { Faculdade } \\
\text { Cambury } \\
\text { (Formosa/GO) }\end{array}$ & $\begin{array}{l}\text { Nós desenvolvemos aqui os projetos integrados, nos quais estão envolvidas todas } \\
\text { as disciplinas do semestre e o principal meio de se obter os recursos } \\
\text { e instrumentos para a realização do projeto é o laboratório de planejamento turístico. }\end{array}$ \\
\hline $\begin{array}{l}\text { Centro de } \\
\text { Educação São } \\
\text { José }\end{array}$ & $\begin{array}{l}\text { O Curso de Turismo e Hotelaria de São José - UNIVALI possui } 5 \text { grandes } \\
\text { trabalhos interdisciplinares: } \\
\text { 1. Sociologia Aplicado ao Turismo - todas disciplinas do } 1^{\circ} \text { período } \\
\text { 2. Campanha de Conscientização Turística - todas disciplinas } 2^{\circ} \text { e } 3^{\circ} \\
\text { 3. Agências de Viagens - todas disciplinas } 5^{\circ} \text { e } 6^{\circ} \text { período; } \\
\text { 4. Planejamento Turístico - disciplinas do } 6^{\circ} \text { e } 7^{\circ} \text { período; } \\
\text { 5. Projeto Integrado do Módulo Hoteleiro - disciplinas } 8^{\circ} \text { e } 9^{\circ} \text { período. } \\
\text { As visitas técnicas na sua grande maioria envolvem a interdisciplinaridade. } \\
\text { Utiliza-se o relatório padrão, tendo como base o relatório de estágio; os } \\
\text { resultados dos trabalhos e a observação dos docentes envolvidos. }\end{array}$ \\
\hline $\begin{array}{l}\text { Faculdade } \\
\text { Metropolitana de } \\
\text { Curitiba/PR }\end{array}$ & $\begin{array}{l}\text { 100\% - nas visitas é possível estabelecer a relação/interação das disciplinas } \\
\text { (que são vistas separadas por questões didáticas) }\end{array}$ \\
\hline $\begin{array}{l}\text { Faculdade } \\
\text { CECAP } \\
\text { (Brasília/DF) }\end{array}$ & $\begin{array}{l}\text { Instrumentos formais ainda não existem, mas estimulamos os trabalhos } \\
\text { interdisciplinares, de modo que os professores de uma mesma turma interajam no } \\
\text { planejamento e desenvolvimento de ações conjuntas. Algumas visitas já foram } \\
\text { realizadas por dois ou mais professores (viagens, p.ex, em que três professores } \\
\text { de diferentes disciplinas organizaram e desenvolveram). }\end{array}$ \\
\hline $\begin{array}{l}\text { Universidade São } \\
\text { Marcos } \\
\text { (São Paulo/SP) }\end{array}$ & $\begin{array}{c}\text { Abrange várias disciplinas: Projeto Hoteleiro, Manutenção, A\&B, Bartender e } \\
\text { gastronomia, Técnica de restaurantes, hospedagem, hospitalidade, } \\
\text { governança, front e back office, Recreação e Lazer, Organização de Eventos, etc. } \\
\text { A ligação é feita através dos relatórios de visitas que são, essencialmente,multidisc } \\
\text { iplinares e, em alguns casos, interdisciplinares. }\end{array}$ \\
\hline
\end{tabular}

$3^{a}$ Questão - Dados sobre a organização da $1^{a}$ e última Visita Técnica por/para cada turma. É possível verificar se houve mudanças nos conceitos dos alunos, tomando-se por base que na maioria das vezes na $1^{a}$ visita técnica os alunos ainda não têm uma visão abrangente (teórica e técnica) sobre a importância da realização da mesma, ao contrário da última, em que se entende que há uma relação mais acadêmica e profissional sobre a utilidade e necessidade de tal atividade - isso pode ser confirmado? 
A sistematização da visita técnica é outro ponto que, pelas informações colhidas, demonstra uma necessidade urgente de promover ou estabelecer um espaço curricular que agregue e conceitue de maneira efetiva e lógica, a relação entre a utilidade e a necessidade de se fazer a visita técnica.

O crescimento e a evolução do discente é o ponto principal dos argumentos colhidos nas informações apresentadas pelas instituições contactadas, conforme indica o Quadro 3.

Quadro 3: Dados sobre a organização da visita técnica

\begin{tabular}{|c|c|}
\hline INSTITUIÇÃO & $\begin{array}{l}\text { 3.Dados sobre a organização da } 1^{a} \text { e última Visita Técnica por/para cada } \\
\text { turma. É possível verificar se houve mudanças nos conceitos dos alunos, } \\
\text { tomando-se por base que na maioria das vezes na } 1^{\mathrm{a}} \text { visita técnica os alunos } \\
\text { ainda não têm uma visão abrangente (teórica e técnica) sobre a importância } \\
\text { da realização da mesma, ao contrário da última, em que se entende que há } \\
\text { uma relação mais acadêmica e profissional sobre a utilidade e necessidade } \\
\text { de tal atividade - isso pode ser confirmado? }\end{array}$ \\
\hline $\begin{array}{l}\text { Faculdade } \\
\text { Cambury } \\
\text { (Formosa/GO) }\end{array}$ & $\begin{array}{l}\text { Nós sistematizamos as visitas técnicas de forma que os alunos possam: } \\
1^{\circ} \text {-visualizar como o espaço pode ser organizado turisticamente, } \\
2^{\circ} \text { - analise do espaço turístico com visão sistêmica } \\
3^{\circ} \text { - turismo cultural histórico como atrativo } \\
4^{o} \text { - análise estrutural dos serviços de hospedagem, alimentos e bebidas } \\
\text { os demais semestres ainda não foram implantados, mas a meta e continuar } \\
\text { dando enfoque a algumas disciplinas chaves e técnicas do turismo. Sabendo } \\
\text { que o curso tem ênfase em planejamento e gestão, os semestres seguintes } \\
\text { deverão ser pautados pela visão do planejamento, desenvolvimento de } \\
\text { projetos e gestão do turismo. }\end{array}$ \\
\hline $\begin{array}{r}\text { Cen } \\
\text { Educa } \\
\mathrm{Jc}\end{array}$ & tendo como \\
\hline $\begin{array}{l}\text { Faculdade } \\
\text { Metropolitana d } \\
\text { Curitiba/PR }\end{array}$ & $\begin{array}{l}\text { É possível verificar a "evolução" dos alunos a partir do q eles deixam escrito } \\
\text { nos seus relatórios. Desde a profundidade das observações até as críticas. }\end{array}$ \\
\hline $\begin{array}{l}\text { Faculdade } \\
\text { CECAP } \\
\text { (Brasília/DF) }\end{array}$ & $\begin{array}{l}\text { Sim. Os alunos aprendem desde a conduta ética e profissional quando } \\
\text { realizam uma visita, assim como têm noção da complexidade das funções } \\
\text { que pretendem assumir. }\end{array}$ \\
\hline $\begin{array}{l}\text { Universidade São } \\
\text { Marcos } \\
\text { (São Paulo/SP) }\end{array}$ & $\begin{array}{l}\text { As visitas são programadas em acordo com a evolução dos Alunos, por exemplo: } \\
\text { Primeiro semestre: o enfoque é a Hospedagem, } \\
\text { Segundo: Hospedagem e A\&B, } \\
\text { Terceiro: Hospitalidade, A\&B, organização de Eventos, } \\
\text { Quarto: igual ao acima mais: Projeto hoteleiro, } \\
\text { Quinto: igual ao acima mais Manutenção e contexto ambiental, E assim em diante. }\end{array}$ \\
\hline
\end{tabular}

$4^{a}$ Questão - Quais são as referências bibliográficas utilizadas para a organização e execução da visita técnica?

Ao considerar a própria dinâmica em que se realiza a visita técnica, de maneira agregada e não integradora, de maneira complementar e não diretiva, verifica-se a ausência de referenciais bibliográficos na maioria das instituições, contribuindo, dessa maneira, para que a visita técnica seja 
apenas um instrumento ou atividade complementar sem nenhum embasamento teórico de sua execução, ainda que secundária.

Não obstante, verificam-se pontos convergentes entre algumas instituições sobre a objetividade de conceituar e utilizar metodologias que indiquem ou demonstrem o que, como, porque e quando fazer a visita técnica. Isto pode ser entendido a partir dos dados expostos no Quadro 4.

Quadro 4: Referências bibliográficas utilizadas para a visita técnica

\begin{tabular}{|c|c|}
\hline INSTITUIÇÃO & $\begin{array}{c}\text { 4.Quais são as referências bibliográficas utilizadas para a organização } \\
\text { e execução da visita técnica? }\end{array}$ \\
\hline $\begin{array}{c}\text { Faculdade } \\
\text { Cambury } \\
\text { (Formosa/GO) }\end{array}$ & $\begin{array}{c}\text { Uma delas é o livro "Visita Técnica", de sua autoria, os "Métodos e técnicas de } \\
\text { pesquisa" da Ada Dencker, entre outros da Área de geografia, investigação } \\
\text { do patrimônio e história. }\end{array}$ \\
\hline $\begin{array}{c}\text { Centro de } \\
\text { Educação São } \\
\text { José }\end{array}$ & $\begin{array}{c}\text { Depende da visita. Entretanto não há uma referência exclusiva sobre visita } \\
\text { técnica. }\end{array}$ \\
\hline $\begin{array}{c}\text { Faculdade } \\
\text { Metropolitana de } \\
\text { Curitiba/PR }\end{array}$ & $\begin{array}{c}\text { Não utilizamos visitas técnicas. Os professores e conselho do curso criaram } \\
\text { a sistemática, regulamentos, formulários e modelos de relatórios }\end{array}$ \\
\hline $\begin{array}{c}\text { Faculdade CECAP } \\
\text { (Brasília/DF) }\end{array}$ & $\begin{array}{c}\text { Os professores usam livros sobre planejamento e organização de eventos e } \\
\text { outros que não tenho informação disponível no momento. Temos profissionais } \\
\text { experientes e todo evento é preparado previamente e são adotadas sistemáticas } \\
\text { de avaliação. }\end{array}$ \\
\hline $\begin{array}{c}\text { Universidade São } \\
\text { Marcos }\end{array}$ & $\begin{array}{c}\text { Todas as referências constam dos planos de ensino e estão disponibilizado } \\
\text { s nas bibliotecas, em nossos bancos de dados e nos softwares específicos } \\
\text { de uso dos nossos Alunos e Professores. }\end{array}$ \\
\hline
\end{tabular}

$5^{a}$ Questão - Como é considerada a visita técnica: para a instituição, para a coordenação do curso, para os professores que auxiliam na organização e execução e para os alunos que executam?

Nas considerações apresentadas pelas instituições os elementos que fortalecem a proposta deste projeto monográfico, estão evidenciados pela unanimidade da importância e da relevância que tem a visita técnica tanto para os discentes, docentes, coordenadores, quanto para a instituição.

Chamam a atenção algumas citações que estão no Quadro 5, sobre como a visita técnica é considerada para as instituições, tais como:

"Algo como Integrante do processo ensino-aprendizagem que estimula o aluno e desperta o interesse na área". (Faculdade CECAP - Brasília/DF)

"Uma ferramenta importante para conhecerem na prática os ensinamentos teóricos".(Universidade São Marcos - São Paulo/SP) 
Quadro 5: Considerações sobre a visita técnica

\begin{tabular}{|c|c|c|c|c|}
\hline \multirow[b]{2}{*}{ INSTITUIÇÃO } & \multicolumn{4}{|c|}{ 5.Como é considerada a visita técnica: } \\
\hline & $\begin{array}{c}\text { Para a } \\
\text { Instituição? }\end{array}$ & $\begin{array}{c}\text { Para a } \\
\text { Coordenação do } \\
\text { Curso? }\end{array}$ & $\begin{array}{c}\text { Para os } \\
\text { professores que } \\
\text { auxiliam na } \\
\text { organização e } \\
\text { execução? }\end{array}$ & $\begin{array}{l}\text { Para os alunos } \\
\text { que executam? }\end{array}$ \\
\hline $\begin{array}{c}\text { Faculdade } \\
\text { Cambury } \\
\text { (Formosa/GO) }\end{array}$ & Essencial. & Fundamental & Prioridade & $\begin{array}{c}\text { Momento de } \\
\text { reflexão da teoria } \\
\text { sobre a prática do } \\
\text { turismo }\end{array}$ \\
\hline $\begin{array}{c}\text { Centro de } \\
\text { Educação São } \\
\text { José }\end{array}$ & Importante. & Importante. & Importante. & Importante. \\
\hline $\begin{array}{c}\text { Faculdade } \\
\text { Metropolitana de } \\
\text { Curitiba/PR }\end{array}$ & $\begin{array}{c}\text { Dinheiro fora do } \\
\text { caixa, pois muitas } \\
\text { são auxiliadas pela } \\
\text { instituição }\end{array}$ & Muito necessárias & $\begin{array}{c}\text { É uma tarefa, tem } \\
\text { que ser cumprida e } \\
\text { bem cumprida }\end{array}$ & $\begin{array}{l}\text { Gostam e acham } \\
\text { importante }\end{array}$ \\
\hline $\begin{array}{c}\text { Faculdade } \\
\text { CECAP } \\
\text { (Brasília/DF) }\end{array}$ & $\begin{array}{c}\text { Como algo } \\
\text { integrante do } \\
\text { processo de } \\
\text { ensino- } \\
\text { aprendizagem que } \\
\text { estimula o aluno e } \\
\text { desperta o } \\
\text { interesse na área. }\end{array}$ & O mesmo. & $\begin{array}{l}\text { Todos os que } \\
\text { normalmente } \\
\text { realizam eventos } \\
\text { compartilham a } \\
\text { importância de tais } \\
\text { empreendimentos. }\end{array}$ & $\begin{array}{l}\text { Eles percebem a } \\
\text { seriedade dos } \\
\text { profissionais que } \\
\text { organizam o } \\
\text { evento e se } \\
\text { sentem } \\
\text { empolgados pela } \\
\text { área. }\end{array}$ \\
\hline $\begin{array}{c}\text { Universidade São } \\
\text { Marcos } \\
\text { (São Paulo/SP) }\end{array}$ & $\begin{array}{l}\text { Uma ferramenta } \\
\text { importante para } \\
\text { conhecerem na } \\
\text { prática os } \\
\text { ensinamentos } \\
\text { teóricos } \\
\end{array}$ & $\begin{array}{l}\text { Uma ferramenta } \\
\text { importante para } \\
\text { conhecerem na } \\
\text { prática os } \\
\text { ensinamentos } \\
\text { teóricos } \\
\end{array}$ & $\begin{array}{l}\text { Uma ferramenta } \\
\text { importante para } \\
\text { conhecerem na } \\
\text { prática os } \\
\text { ensinamentos } \\
\text { teóricos } \\
\end{array}$ & $\begin{array}{c}\text { Idem, além da } \\
\text { oportunidade de } \\
\text { conhecerem } \\
\text { possíveis } \\
\text { empregadores e/ou } \\
\text { locais para estágios }\end{array}$ \\
\hline
\end{tabular}

$6^{a}$ Questão - Dados sobre a estruturação da visita técnica em banco de dados, informações, registro, seminários.

A produção da visita técnica é importante para se diagnosticar os resultados obtidos através da relação técnica e prática, conciliando o saber científico transmitido pela academia e o senso comum visualizado quando da presença às localidades e atrativos visitados.

Desse modo, o que se percebe na maioria das instituições contactadas é a disposição em registrar e compor através de banco de dados todas as atividades desenvolvidas com as visitas técnicas, bem como realizar seminários, confeccionar relatórios, enfim, produzir todo um arcabouço de informações e dados escritos, visuais, fonográficos e tecnológicos. (Vide Quadro 6) 
Essas iniciativas também são referenciais consideráveis para os argumentos sobre a importância da visita técnica para os cursos de turismo, para a sua plenitude "disciplinativa".

Quadro 6: Dados sobre a estruturação da visita técnica

\begin{tabular}{|c|c|}
\hline INSTITUIÇÃO & $\begin{array}{l}\text { 6.Dados sobre a estruturação da visita técnica em banco de dados, } \\
\text { informações, registro, seminários; }\end{array}$ \\
\hline $\begin{array}{l}\text { Faculdade } \\
\text { Cambury } \\
\text { (Formosa/GO) }\end{array}$ & $\begin{array}{c}\text { As visitas técnicas são registradas em fotos e vídeos, catalogadas e } \\
\text { arquivadas no laboratório de planejamento turístico. Também são divulgadas } \\
\text { pelo jornal de circulação interno na faculdade. }\end{array}$ \\
\hline $\begin{array}{l}\text { Centro de } \\
\text { Educação São } \\
\text { José }\end{array}$ & $\begin{array}{c}\text { Ao término das visitas técnicas, dependendo da mesma, os docentes } \\
\text { realizam após análise dos relatórios seminários com os discentes envolvidos } \\
\text { para discussão dos resultados. }\end{array}$ \\
\hline $\begin{array}{l}\text { Faculdade } \\
\text { Metropolitana de } \\
\text { Curitiba/PR }\end{array}$ & Nos livros de chamada das disciplinas \\
\hline $\begin{array}{l}\text { Faculdade } \\
\text { CECAP } \\
\text { (Brasília/DF) }\end{array}$ & $\begin{array}{c}\text { Estamos desenvolvendo na homepage da Faculdade a opção do banco de } \\
\text { dados desses eventos, com os planejamentos, avaliações e atividades } \\
\text { realizadas pelos alunos. }\end{array}$ \\
\hline $\begin{array}{c}\text { Universidade São } \\
\text { Marcos } \\
\text { (São Paulo/SP) }\end{array}$ & $\begin{array}{c}\text { Claro, temos um laboratório de informática específico para estas } \\
\text { finalidades. }\end{array}$ \\
\hline
\end{tabular}

$7^{a}$ Questão - Informar em números ou percentuais: Visitas técnicas realizadas por ano; Quantidades de docentes e discentes que participam; Citar as 03 primeiras localidades onde se realizam mais visitas; O tempo médio (quantidade de dias) gasto para realização das visitas; Tipo de veículos que utilizam; Tipo de hospedagem; Outros dados que puderem disponibilizar que consideram de real importância para a realização da visita técnica.

Ao requerer informações das IES sobre a realização das visitas técnicas, localidades e atrativos visitados, tempo de realização das visitas, veículos que utilizam, tipos de hospedagem e outros dados de real importância para a consecução das visitas técnicas, podemos perceber que esta "atividade" já está inserida na concepção pedagógica dos cursos de turismo (vide Quadro 7), necessitando única e exclusivamente, de uma referência conceitual de caráter didático, metodológico enfim de cunho dialético, para estabelecer, de forma não exclusivista, mas, de maneira especial, como ferramenta indispensável para a melhoria da compreensão do discente sobre a indústria, o setor, o fenômeno social, ciência que é o turismo. 
Interessante e digno de registro é a citação da Univali-Centro de Educação São José sobre a real importância para a realização das vistas técnicas:

1.Definição da importância da interdisciplinaridade para o crescimento do Curso, docentes e discentes;

2. Ter a visita técnica como importante pilar da interdisciplinaridade.

A estrutura da obtenção dos resultados das visitas (relatórios, seminários, entres outros)

Verifica-se, nas respostas apresentadas, que o processo de aplicação da visita técnica, na grande maioria, não obedece alguns parâmetros de coordenação, organização e orientação específica, onde a mesma em determinada instituição tem a sua consecução privilegiada e dinamizada por instrumentos que assim a classificam e em outras é tida apenas como instrumento ou ferramenta utilizada para complementar o processo didático e pedagógico de uma ou mais disciplinas, não se evidenciando, dessa forma a qualificação da interdisciplinaridade, apesar de assim considerarem.

Os elementos dessa interpretação e análise podem ser observados tanto nas respostas das outras questões bem como no desenvolvimento desse trabalho quando se referenda a interdisciplinaridade como base de sustentação para a instituição da visita técnica como disciplina curricular. 
Quadro 7: Informações e dados sobre a realização e a importância das visita técnicas

\begin{tabular}{|c|c|c|c|c|c|c|c|}
\hline \multirow{2}{*}{ INSTITUIÇÃO } & \multicolumn{7}{|c|}{ 7.Informar em números ou percentuais } \\
\hline & $\begin{array}{l}\text { Visitas } \\
\text { técnicas } \\
\text { realizadas } \\
\text { por ano }\end{array}$ & $\begin{array}{l}\text { Quantidades de } \\
\text { docentes e } \\
\text { discentes que } \\
\text { participam }\end{array}$ & $\begin{array}{l}\text { Citar as } 03 \text { primeiras } \\
\text { localidades onde se } \\
\text { realizam mais } \\
\quad \text { visitas }\end{array}$ & $\begin{array}{l}\text { O tempo médio } \\
\text { (qtde. de dias) } \\
\text { gasto pra } \\
\text { realização das } \\
\text { visitas }\end{array}$ & $\begin{array}{c}\text { Tipo de } \\
\text { veículos que } \\
\text { utilizam }\end{array}$ & $\begin{array}{c}\text { Tipo de } \\
\text { hospedagem }\end{array}$ & $\begin{array}{l}\text { Outros dados que puderem disponibilizar que } \\
\text { consideram de real importância para a } \\
\text { realização da visita técnica. }\end{array}$ \\
\hline $\begin{array}{l}\text { Faculdade Cambury } \\
\text { (Formosa/GO) }\end{array}$ & 14 & $\begin{array}{l}\text { Em média } \\
3 \text { professores } \\
\text { e } 30 \text { alunos }\end{array}$ & $\begin{array}{l}\text { Formosa, Brasília, } \\
\text { cidades históricas } \\
\text { goianas }\end{array}$ & $\begin{array}{l}\text { Em loco } 2 \text { dias, } \\
\text { de preparação } \\
40 \text { dias }\end{array}$ & $\begin{array}{l}\text { Ônibus e } \\
\text { micro-ônibus }\end{array}$ & $\begin{array}{l}\text { Hotéis e } \\
\text { pousadas. }\end{array}$ & $\begin{array}{l}\text { Se precisar de mais dados } \\
\text { informe precisamente. }\end{array}$ \\
\hline $\begin{array}{l}\text { Centro de Educação } \\
\text { São José }\end{array}$ & $\begin{array}{l}\text { Varia, não } \\
\text { temos um } \\
\text { padrão de } \\
\text { números }\end{array}$ & $\begin{array}{l}\text { Depende da visita. } \\
\text { Geralmente entre } 2 \\
\text { a } 3 \text { docentes }\end{array}$ & $\begin{array}{c}\text { São José; } \\
\text { Florianópolis; } \\
\text { Balneário Camboriú }\end{array}$ & $\begin{array}{c}\text { Na sua grande } \\
\text { maioria apenas } 1 \\
\text { dia }\end{array}$ & Ônibus & Hotel & $\begin{array}{l}\text { 1.Definição da importância da interdisciplinaridade } \\
\text { para o crescimento do Curso, docentes e discentes; } \\
\text { 2.Ter a visita técnica como importante pilar da } \\
\text { interdisciplinaridade. } \\
\text { A estrutura da obtenção dos resultados das visitas } \\
\text { (relatórios, seminários, entres outros) }\end{array}$ \\
\hline $\begin{array}{l}\text { Faculdade } \\
\text { Metropolitana de } \\
\text { Curitiba/PR }\end{array}$ & $\begin{array}{l}4 \text { por ano por } \\
\text { turma... } \\
\text { mínimo...qto } \\
\text { mais, melhor }\end{array}$ & $\begin{array}{l}\text { Todas as turmas } \\
\text { têm que comparecer } \\
\text { e os docentes } \\
\text { acompanham }\end{array}$ & $\begin{array}{l}\text { Município, Cidade } \\
\text { maior mais próxima, } \\
\text { Ilha do Mel }\end{array}$ & $\begin{array}{l}\text { Depende... } 1 \text { dia } \\
\text { para cada cidade } \\
\text { e llha são dois }\end{array}$ & Van e ônibus & $\begin{array}{c}\text { Hotell } \\
\text { Pousada }\end{array}$ & 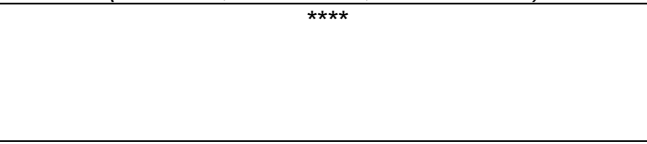 \\
\hline $\begin{array}{l}\text { Faculdade CECAP } \\
\text { (Brasília/DF) }\end{array}$ & $\begin{array}{l}10 \text { visitas de } \\
\text { um dia e duas } \\
\text { viagens em } \\
\text { final de } \\
\text { semana. }\end{array}$ & $\begin{array}{l}\text { Cerca de } 10 \\
\text { professores }\end{array}$ & $\begin{array}{c}\text { Hotéis } \\
\text { Restaurantes } \\
\text { Feiras/eventos }\end{array}$ & $\begin{array}{l}\text { Visitas de um dia } \\
\text { ou viagens de } \\
\text { dois dias }\end{array}$ & Ônibus & $\begin{array}{l}\text { Quartos duplos } \\
\text { ou triplos }\end{array}$ & $\begin{array}{l}\text { Dados dos alunos: uso de medicamentos; } \\
\text { autorização para os menores etc. } \\
\text { Dados do transporte: licença etc. }\end{array}$ \\
\hline $\begin{array}{c}\text { Universidade São } \\
\text { Marcos (São Paulo/SP) }\end{array}$ & 27 a 30/ano & $\begin{array}{l}\text { Docentes e } \\
\text { Monitores: } 07 \\
\text { Alunos: } 266\end{array}$ & $\begin{array}{c}\text { Sabauna-SP(*), São } \\
\text { Sebastião }\left(^{\star}\right) \\
\left(^{\star}\right) \text { Ver detalhes das } \\
\text { instalações próprias } \\
\text { para a prática do } \\
\text { Ecoturismo e Turismo } \\
\text { Rural na apresentação } \\
\text { do nosso Curso de } \\
\text { Tecnologia em } \\
\text { Ecoturismo, anexo. } \\
\end{array}$ & $\begin{array}{l}\text { Em São Paulo: } 6 \\
\text { horas } \\
\text { Outros: Um fim de } \\
\text { semana }\end{array}$ & Ônibus & $\begin{array}{l}\text { Próprias, } \\
\text { oferecidas pela } \\
\text { Universidade } \\
\text { São Marcos }\end{array}$ & 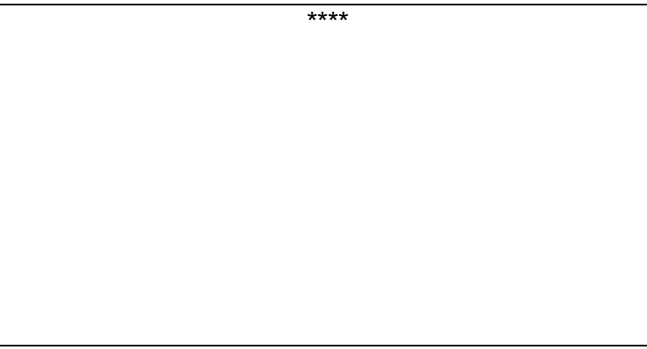 \\
\hline
\end{tabular}




\subsection{2-Ação 2 - Pesquisa aos sites das IES}

Em função disso, como já citado anteriormente, foi desenvolvida a Ação 2 , que se refere a coleta de dados e informações constantes nos sites das IES selecionadas no que se refere ao perfil do curso, projetos pedagógicos, grades (fluxos) curriculares e ementário, entre outros dados de interesse.

Feito isso, foram elaboradas planilhas e gráficos que permitem verificar as disciplinas existentes e predominantes do $1^{\circ}$ ao $4^{\circ}$ ano dos Cursos de Turismo (tomando-se por base as grades ou fluxos curriculares) as similaridades das ementas disponibilizadas, os perfis do curso e do profissional de turismo e os projetos pedagógicos identificados nos sites.

Os cursos de graduação em turismo, conforme pesquisa realizada junto ao site da Associação Brasileira dos Bacharéis em Turismo-ABBTUR, apresentam as seguintes características (Gráfico 2):

a)Para a maioria dos cursos está consignada a expressão simples de "Graduação em Turismo", sem indicativos complementares ou ênfases;

b)Em segundo lugar vêm os cursos de "Graduação em Turismo e Hotelaria";

c)Em terceiro lugar aparecem os cursos de "Graduação em Turismo com ênfase em Ecoturismo, Meio ambiente ou ambiente naturais" e "Graduação em Tecnologia em Turismo e/ou Hospitalidade".

Gráfico 2: Cursos de Turismo - Graduação e ênfases

\begin{tabular}{l}
\hline Graduação em Turismo \\
$\square$ Grad. em Turismo com ênfase em Ecoturismo, Meio Ambiente ou ambient \\
naturais \\
Grad. em Turismo e Hotelaria \\
Grad. em Tecnologia em Turismo e/ou Hospitalidade \\
$\square$ Outros \\
\hline
\end{tabular}


Tabela 1: Cursos de Turismo - graduação e ênfases

\begin{tabular}{|c|c|c|c|c|c|c|c|c|c|c|c|c|}
\hline Estados & $\begin{array}{l}\text { Graduação } \\
\text { em Turismo }\end{array}$ & \begin{tabular}{|c|} 
Grad. em \\
Turismo com \\
ênfase em \\
Ecoturismo, \\
Meio \\
Ambiente ou \\
ambientes \\
naturais \\
\end{tabular} & \begin{tabular}{|c|} 
Grad. em \\
Turismo \\
c/ ênfase \\
em \\
Eventos \\
\end{tabular} & $\begin{array}{c}\text { Grad. em } \\
\text { Turismo cl } \\
\text { ênfase em } \\
\text { Planejamen } \\
\text { to Turístico }\end{array}$ & $\begin{array}{l}\text { Grad. em } \\
\text { Turismo e } \\
\text { Hotelaria }\end{array}$ & $\begin{array}{c}\text { Grad. em } \\
\text { Tecnologia } \\
\text { em Turismo } \\
\text { e/ou } \\
\text { Hospitalidade }\end{array}$ & \begin{tabular}{|c|} 
Grad. em \\
Turismo, \\
Eventos, \\
Lazer ou \\
entretenime \\
nto
\end{tabular} & \begin{tabular}{|c|} 
Grad. em \\
Tecnologia \\
em \\
Hotelaria \\
e/ou \\
Eventos
\end{tabular} & $\begin{array}{l}\text { Grad. em } \\
\text { Hotelaria }\end{array}$ & $\begin{array}{c}\text { Outros }\left(^{*}\right) \\
01 \text { de cada }\end{array}$ & $\begin{array}{c}\text { Sem } \\
\text { Informações }\end{array}$ & TOTAL \\
\hline Acre & 1 & & & & & & & & & & & 1 \\
\hline Alagoas & 3 & & & & & & & & & & & 3 \\
\hline Amapá & 2 & & & & & & & & & & & 2 \\
\hline Amazonas & 5 & & & & & & 1 & & & & & 6 \\
\hline Bahia & 25 & & & & & & & & & & & 25 \\
\hline Ceará & 6 & & & & & & & & & & & 6 \\
\hline Distrito Federal & 9 & 1 & 1 & & & & & & & 2 & 1 & 14 \\
\hline Espírito Santo & 10 & & & & & & & & & & & 10 \\
\hline Goiás & 10 & & & & & 1 & & & & 1 & & 12 \\
\hline Maranhão & 6 & & & 1 & & & & & & & & 7 \\
\hline Mato Grosso & 8 & & & & & & & & & & & 8 \\
\hline Mato Grosso do Sul & 13 & 1 & & & & & & & & 1 & & 15 \\
\hline Minas Gerais & 35 & 1 & & & 1 & & & & & & & 37 \\
\hline Pará & 2 & & & & & & & & & & & 2 \\
\hline Paraíba & 5 & & & & & & & & & & & 5 \\
\hline Paraná & 30 & & 1 & & 7 & & & 1 & 1 & & & 40 \\
\hline Pernambuco & 17 & 1 & & & & & & & 1 & & & 19 \\
\hline Piauí & 4 & & & & & & & & & & & 4 \\
\hline
\end{tabular}




\begin{tabular}{|c|c|c|c|c|c|c|c|c|c|c|c|c|}
\hline Estados & $\begin{array}{l}\text { Graduação } \\
\text { em Turismo }\end{array}$ & \begin{tabular}{|c|} 
Grad. em \\
Turismo \\
com ênfase \\
em \\
Ecoturismo, \\
Meio \\
Ambiente ou \\
ambientes \\
naturais \\
\end{tabular} & \begin{tabular}{|} 
Grad. em \\
Turismo \\
c/ ênfase \\
em \\
Eventos
\end{tabular} & $\begin{array}{c}\text { Grad. em } \\
\text { Turismo cl } \\
\text { ênfase em } \\
\text { Planejament } \\
\text { o Turístico }\end{array}$ & $\begin{array}{l}\text { Grad. em } \\
\text { Turismo e } \\
\text { Hotelaria }\end{array}$ & $\begin{array}{c}\text { Grad. em } \\
\text { Tecnologia } \\
\text { em Turismo } \\
\text { e/ou } \\
\text { Hospitalidade }\end{array}$ & \begin{tabular}{|c|} 
Grad. em \\
Turismo, \\
Eventos, \\
Lazer ou \\
entretenime \\
nto
\end{tabular} & $\begin{array}{c}\text { Grad. em } \\
\text { Tecnologia } \\
\text { em } \\
\text { Hotelaria } \\
\text { e/ou } \\
\text { Eventos }\end{array}$ & $\begin{array}{l}\text { Grad. em } \\
\text { Hotelaria }\end{array}$ & $\begin{array}{c}\text { Outros }\left(^{*}\right) \\
01 \text { de cada }\end{array}$ & $\begin{array}{c}\text { Sem } \\
\text { Informações }\end{array}$ & TOTAL \\
\hline Rio de Janeiro & 24 & & & & & & & & & & & 24 \\
\hline Rio Grande do Norte & 2 & & & & & & & & & & 1 & 3 \\
\hline Rio Grande do Sul & 11 & & & & 1 & & & & & & & 12 \\
\hline Rondônia & 2 & & & & & & & & & & & 2 \\
\hline Santa Catarina & 14 & & & & 2 & 1 & 1 & & & 1 & & 19 \\
\hline São Paulo & 132 & 2 & & 1 & 2 & 4 & 1 & 3 & 1 & 1 & & 147 \\
\hline Sergipe & 2 & & & & & & & & & & & 2 \\
\hline \multirow[t]{2}{*}{ Tocantins } & 1 & & & & & & & & & & & 1 \\
\hline & 379 & 6 & 2 & 2 & 13 & 6 & 3 & 4 & 3 & 6 & 2 & 426 \\
\hline
\end{tabular}

\section{Outros (*)}

- Grad. em Turismo c/ ênfase em Meio Ambiente e Eventos

- Grad. em Turismo c/ ênfase em Hotelaria, Meio Ambiente e Marketing

- Grad. em Turismo c/ ênfase em Hotelaria ou Turismo Ambiental

- Grad. em Turismo c/ ênfase em Hotelaria e Eventos

- Grad. em Turismo c/ ênfase Empreendedorismo

- Gestão Hoteleira

Fonte: www.abbtur.com.br (Nov/2003) 

Importante ressaltar que não foram computados, para análise deste trabalho, os cursos de Administração em Turismo, vez que o que se pretendia era observar as características diretas da expressão "Graduação em Turismo" e suas referências complementares ou ênfases, para o aprofundamento do entendimento da ação da visita técnica e a sua complexidade turística. Não obstante, pode se verificar na relação (Anexo $\mathrm{C}$ ) dos cursos de turismo, a inserção dos cursos de Administração em Turismo e Tecnologia em Turismo.

Foram relacionadas 426 Instituições de Ensino Superior no Brasil que possuem cursos de turismo e hotelaria e, conforme pode ser verificado na Tabela 1, tem-se, por estado, a demonstração em quantidade das referências de graduação e ênfases existentes.

O intüito de se apresentar o quantitativo de cursos por estado deve-se ao fato de que a proposta desta monografia deve ser absorvida por todas as regiões, independente das diferenças regionais, especificações ou ênfases que os cursos possuem e da estrutura turística que formata ou permeia a presença dos cursos de turismo em cada estado.

Outro ponto de indicação dos cursos é de servir como parâmetro para futuras pesquisas, de caráter didático e metodológico, para aferição e parametrização da proposta disciplinar dos projetos pedagógicos.

\section{IES pesquisadas - informações e dados}

De caráter aleatório, foram coletados dados junto à 40 instituições de ensino superior, através de pesquisa nos sites das mesmas, onde se buscavam informações sobre os seguintes dados e informações:
a) Perfil do curso
b) Perfil do profissional de turismo
c) Ementas das disciplinas
d) Disciplinas constantes nas grades ou fluxos curriculares
e) Dados e informações sobre visita técnica ou similar 
Quadro 8: Instituições de Ensino Superior pesquisadas

\begin{tabular}{|c|c|c|c|c|c|c|c|}
\hline \multicolumn{3}{|c|}{ INSTITUIÇÕES } & \multicolumn{5}{|c|}{ INFORMAÇÕES DISPONIBILIZADAS NO SITE } \\
\hline Nome & $\begin{array}{l}\text { Cidade/ } \\
\text { Estado }\end{array}$ & Site & $\begin{array}{c}\text { Perfil } \\
\text { do } \\
\text { curso }\end{array}$ & $\begin{array}{c}\text { Perfil do } \\
\text { Profissional de } \\
\text { turismo } \\
\text { (graduando) }\end{array}$ & $\begin{array}{l}\text { Grade } \\
\text { Curricular }\end{array}$ & $\begin{array}{c}\text { Ementas das } \\
\text { disciplinas do } \\
\text { curso de } \\
\text { turismo }\end{array}$ & $\begin{array}{c}\text { Informações } \\
\text { sobre Visita } \\
\text { Técnica e ou } \\
\text { Pesquisa de } \\
\text { campo }\end{array}$ \\
\hline Centro de Estudos Superiores de Maceió & Maceió/AL & www.fejal.com.br & $x$ & $x$ & $x$ & & \\
\hline $\begin{array}{l}\text { Centro Integrado de Ensino Superior da } \\
\text { Amazônia }\end{array}$ & Manaus/AM & www.ciesa.br & $x$ & $x$ & $x$ & $x$ & \\
\hline Faculdade Nilton Lins & Manaus/AM & www. niltonlins. br & $x$ & $x$ & $x$ & $x$ & \\
\hline Associação Educacional da Amazônia & Macapá/AP & www.seama.edu.br & $x$ & $x$ & $x$ & & \\
\hline Faculdades Integradas da Bahia & Salvador/BA & www.fib.br & $x$ & $x$ & $x$ & $x$ & $x$ \\
\hline Faculdade Santíssimo Sacramento & Salvador/BA & www.fsssacramento.br & $x$ & $x$ & $x$ & & \\
\hline Faculdades Integradas do Ceará & Fortaleza/CE & www.fic.br & $x$ & $x$ & $x$ & & \\
\hline Faculdade CECAP & Brasília/DF & www.cecap.com.br & $x$ & $x$ & $X$ & $x$ & \\
\hline Centro Universitário Vila Velha & Vila Velha/ES & www.uvv-es.br & $\mathrm{X}$ & $\mathrm{X}$ & $\mathrm{X}$ & & \\
\hline Faculdade Alves Faria-Alfa & Goiânia/GO & www.alfa.br & $x$ & $x$ & $x$ & & $x$ \\
\hline Faculdade Cambury & Formosa/GO & www.cambury.br & $x$ & $x$ & $x$ & & \\
\hline Unicaldas & Caldas Novas/GO & www.unicaldas.edu.br & $x$ & $x$ & $x$ & & \\
\hline Faculdade Atenas Maranhense & São Luis/MA & www.fama.br & & & & & \\
\hline Universidade Federal do Maranhão & São Luis/MA & www.ufma.br & $x$ & $x$ & $x$ & & \\
\hline Faculdade Santa Marta & São Lourenço/MG & www.faculdadesantamarta.br & $x$ & $x$ & $x$ & & \\
\hline Pontifícia Universidade Católica & Poços de Caldas/MG & www.pucminas.br & $x$ & $x$ & $x$ & $x$ & \\
\hline Unicentro Newton Paiva & Belo Horizonte/MG & www. newtonpaiva.br & $x$ & $x$ & $x$ & & \\
\hline Centro Universitário Triângulo-Unit & Uberlândia/MG & www.unitmg.com.br & $x$ & $x$ & & & \\
\hline Uniube & Uberaba/MG & www.uniube.br & $x$ & $x$ & & & \\
\hline Universidade Federal de Ouro Preto & Ouro Preto/MG & www.ufop.br & $x$ & $x$ & $x$ & & \\
\hline Centro Universitário da Grande Dourados & Dourados/MS & www.unigran.br & $\mathrm{X}$ & $\mathrm{X}$ & $\mathrm{X}$ & & \\
\hline Faculdade Asper & João Pessoa/PB & www.asper.com.br & $x$ & $x$ & $x$ & & \\
\hline Universidade Católica de Pernambuco-Unicap & Recife/PE & www.unicap.br & $x$ & $x$ & & & \\
\hline Universidade Federal do Pernambuco & Recipe/PE & www.ufpe.com.br & $X$ & $x$ & $x$ & & \\
\hline Associação de Ensino Superior do Piauí & Teresina/PI & www.aespi.br & $X$ & $x$ & $x$ & & \\
\hline Faculdade Metropolitana de Curitiba & Curitiba/PR & www.famec.com.br & $\mathrm{X}$ & $\mathrm{X}$ & $\mathrm{X}$ & & \\
\hline Pontifícia Universidade Católica & Curitiba/PR & www.pucpr.br & $x$ & $x$ & $x$ & & \\
\hline Unioeste & Foz do Iguaçu/PR & www.unioeste.br & $x$ & $x$ & $x$ & & \\
\hline
\end{tabular}




\begin{tabular}{|c|c|c|c|c|c|c|c|}
\hline \multicolumn{3}{|c|}{ INSTITUIÇÕES } & \multicolumn{5}{|c|}{ INFORMAÇÕES DISPONIBILIZADAS NO SITE } \\
\hline Nome & $\begin{array}{l}\text { Cidade/ } \\
\text { Estado }\end{array}$ & Site & $\begin{array}{l}\text { Perfil } \\
\text { do } \\
\text { curso }\end{array}$ & $\begin{array}{c}\text { Perfil do } \\
\text { Profissional de } \\
\text { turismo } \\
\text { (graduando) }\end{array}$ & $\begin{array}{c}\text { Grade } \\
\text { Curricular }\end{array}$ & $\begin{array}{c}\text { Ementas das } \\
\text { disciplinas do } \\
\text { curso de } \\
\text { turismo }\end{array}$ & $\begin{array}{c}\text { Informações sobre } \\
\text { Visita Técnica e } \\
\text { ou Pesquisa de } \\
\text { campo }\end{array}$ \\
\hline Universidade Federal do Paraná & Curitiba/PR & $\underline{w w w . u f p r . b r}$ & $X$ & $x$ & & & \\
\hline Faculdades Integradas Hélio Alonso & Rio de Janeiro/RJ & www.facha.br & $x$ & $x$ & $x$ & & \\
\hline Centro Universitário da Cidade/Univercidade & Rio de Janeiro/RJ & www.univercidade.br & $x$ & $x$ & $x$ & $x$ & $X$ \\
\hline Universidade Veiga de Almeida & Rio de Janeiro/RJ & www.uva.br & $\mathrm{X}$ & $\mathrm{X}$ & & & \\
\hline Pontifícia Universidade Católica & Porto Alegre/RS & www.pucrs.br & & & $\mathrm{X}$ & & \\
\hline Universidade Caxias do Sul & Caxias do Sul/RS & www.ucs.br & $\mathrm{X}$ & $\mathrm{X}$ & $\mathrm{X}$ & & \\
\hline Centro Universitário São José-Univali & São José/SC & www.univali.br & $\mathrm{x}$ & $\mathrm{X}$ & & & \\
\hline Instituto Blumenauense de Ensino Superior & Blumenau/SC & www.unibes.com.br & $\mathrm{x}$ & $\mathrm{x}$ & $\mathrm{X}$ & $\mathrm{x}$ & \\
\hline Universidade Anhembi Morumbi & São Paulo/SP & www.anhembi.br & $\mathrm{x}$ & $\mathrm{x}$ & $\mathrm{X}$ & & \\
\hline Universidade Barão de Mauá & Ribeirão Preto/SP & www.baraodemaua.br & $\mathrm{X}$ & $\mathrm{X}$ & $\mathrm{X}$ & & \\
\hline Universidade São Marcos & São Paulo/SP & www.smarcos.br & $\mathrm{X}$ & $\mathrm{X}$ & & & \\
\hline Universidade de Franca & Franca/SP & www.unifran.br & $\mathrm{X}$ & $\mathrm{X}$ & $\mathrm{X}$ & & \\
\hline
\end{tabular}

Gráfico 3: Informações e dados disponibilizados nos sites

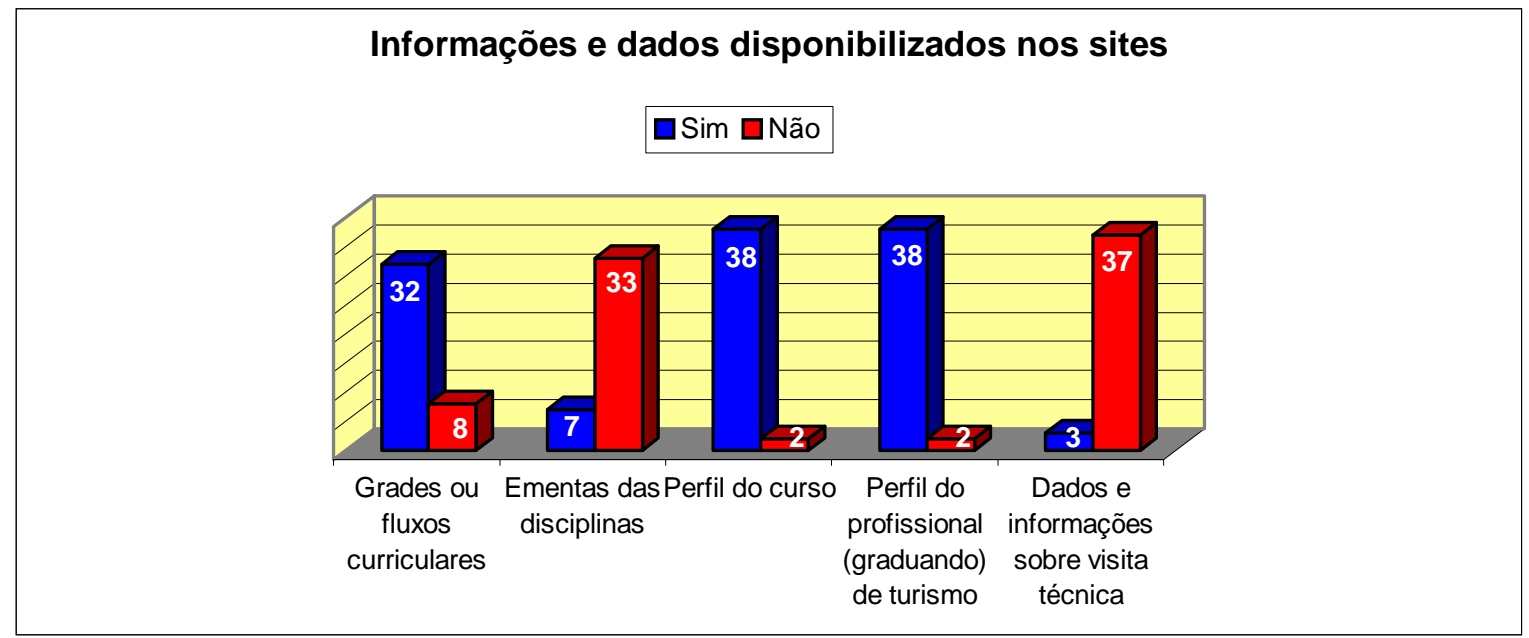


Assim, de acordo com o Quadro 8, pode-se constatar que das 40 instituições pesquisadas obteve-se os seguintes resultados: (Vide Gráfico 3)

Grades ou fluxos curriculares

- 32 disponibilizadas no site;

- 08 não disponibilizadas no site.

Ementas das disciplinas

- 07 disponibilizadas no site;

- 33 não disponibilizadas no site.

Perfil do curso

- 38 disponibilizadas no site;

- 02 não disponibilizadas no site.

Perfil do profissional (graduando) de turismo

- 38 disponibilizadas no site;

- 02 não disponibilizadas no site.

Dados e informações sobre visita técnica ou similares

- 03 disponibilizadas no site;

- 37 não disponibilizadas no site.

\section{Detalhamento de dados e informações}

Diante dos dados apresentados foram observadas as relações existentes com as visitas técnicas, bem como alguns elementos que constituem os projetos pedagógicos desses cursos.

A partir da amostragem das disciplinas curriculares constantes nas grades dessas instituições, estabelecemos o critério de codificar a denominação referencial (título-mestre) e das suas variáveis (título-complementar), no sentido de estabelecer um parâmetro de construção interdisciplinar para fazer face ao entendimento de que a produção ou resultados dessas disciplinas é ponto de convergência para a proposta integrativa da institucionalização da visita técnica como disciplina curricular.

Sobre as disciplinas consultadas e apresentadas no Apêndice C permitem verificar que algumas já existentes nos fluxos (grades) curriculares possibilitam, 
inclusive, servir de referencial para a absorção ou transformação das mesmas em atividades similares à visita técnica de conformidade com os estudos diagnosticados e exposta neste projeto monográfico. Diante dessas ponderações, serão apresentadas e comentadas abaixo algumas características verificadas nos fluxos (grades) curriculares bem como das ementas e perfis dos cursos e do profissional pesquisadas.

Disciplina de características similares à visita técnica

O Quadro 9 refere-se a dados extraídos do Apêndice C e que são interessantes de observados pois tratam-se das atividades de determinadas disciplinas que são evidenciadas com algumas características da visita técnica e que, a partir de uma estruturação didática e metodológica podem ser concebidas como um espaço curricular ou disciplinar que produza resultado mais amplo, configurando os termos da visita técnica e, evidentemente, se estabelecer como âncora da pesquisa científica, da produção do conhecimento.

Quadro 9: Atividades curriculares de características similares à visita técnica

\begin{tabular}{|l|l|c|}
\hline \multicolumn{1}{|c|}{ Disciplina referência } & \multicolumn{1}{c|}{$\mathbf{1}^{\circ}$ ANO } & Qtde \\
\hline ATIVIDADES COMPLEMENTARES & ATIVIDADES COMPLEMENTARES & 2 \\
\hline & PESQUISA TEMÁTICA & 1 \\
\hline ATIVIDADES DE PRÁTICAS ORIENTADAS & VISITA TÉCNICA E RELATÓRIOS & 1 \\
\hline VISITA TÉCNICA & ATIVIDADES DE PRÁTICAS ORIENTADAS & 1 \\
\hline
\end{tabular}

\section{Ementas e perfis do curso e do profissional de turismo}

O Quadro 8 traz os dados colhidos sobre as referências constantes nas ementas e nos perfis do curso e do profissional de turismo, que permite estabelecer "quase" que uma "injunção" da existência da disciplina visita técnica nos projetos pedagógicos pela clareza em que se propõe a interdisciplinaridade e a integração da teoria com a prática.

No sentido de validar esta constatação, verificam-se nos Quadros 10 e 11, alguns dados extraídos dos sites de três instituições pesquisadas que disponibilizam uma especial atenção à visita técnica. 
Ressalta-se que os estudos, muitas vezes especificados nos perfis do curso, predispõem uma rigorosa atenção para a necessidade da atividade de pesquisa em função do entendimento e do cruzamento dos ensinamentos teóricos com o aprendizado da atividade prática, principalmente pela substancialidade em que se referenda o destino do exercício profissional, ou seja, em sua maioria, o mercado.

Não obstante, o uso constante do termo "preparação do profissional de turismo para o mercado", é de suma importância que as instituições de ensino superior, principalmente ou particularmente, as que detêm os cursos de turismo, hotelaria e hospitalidade, envidem todos os esforços para que o processo de ordenação seja coroado de êxito e sucesso, tendo como "diferencial profissional" a ação da pesquisa, iniciando-se pela visita técnica, seja, a partir da observação sistemática, como indicador mais característico, seja, a partir da observação assistemática ou documental e, por que não dizer, vislumbrar o experimento que possa propiciar a notabilização do discente.

Os argumentos dessa proposta estão evidenciados no Capítulo 5 e que tem como símbolo os mesmos parâmetros em que se compilam as disciplinas já existentes.

Quadro 10: Visita técnica na grade curricular

\begin{tabular}{|c|c|}
\hline \multicolumn{2}{|c|}{$\begin{array}{l}\text { Turismo | Grade curricular } \\
\text { Grade Curricular Seriada do Curso de Turismo das Faculdades Alves Faria }\end{array}$} \\
\hline \multicolumn{2}{|l|}{$1^{\circ}$ Semestre } \\
\hline Língua Portuguesa I & $36 \mathrm{~h}$ \\
\hline Hospedagem I & $36 \mathrm{~h}$ \\
\hline Fundamentos de Ecologia & $36 \mathrm{~h}$ \\
\hline Administração I & $72 \mathrm{~h}$ \\
\hline Geografia Aplicada & $72 \mathrm{~h}$ \\
\hline Introdução ao Turismo & $72 \mathrm{~h}$ \\
\hline VISITA TÉCNICA & $36 \mathrm{~h}$ \\
\hline CARGA TOTAL & $360 h$ \\
\hline
\end{tabular}


Quadro 11: Visitas Técnicas nos cursos de turismo

\section{รี้ \\ FACULDADE INTECRADA OA BAHIA \\ TURISMO - FIB}

\section{VISITA TÉCNICA}

As visitas técnicas do Curso de turismo da FIB tem surtido grande efeito. Os alunos têm não só aprendido o conteúdo da disciplina, mas também, desenvolvido habilidades essenciais de gestão.

As aulas " in loco " possibilitam uma visão sistêmica, essencial para que a educação turística cumpra o seu papel, assegurando a associação de teoria à prática.

As visitas técnicas desenvolvidas

interdisciplinarmente em hotéis fazenda, ambientes rurais, empreendimentos que trabalham com

segmentações de mercado, tem ajudado o aluno à colocar-se no papel de empreendedor a partir do momento que existe uma orientação para análise, discussão e debate.

Um exemplo é o trabalho que está sendo desenvolvido no município de Una, com o 70

semestre, através de uma parceria entre a Prefeitura, o município e a Faculdade Integrada da Bahia. A parceria consiste no apoio da a Prefeitura aos alunos para a elaboração de uma proposta de

desenvolvimento turístico para o Município.

\section{U N I V E R}

C I D $\triangle \mathrm{DE}$

\section{.}

\section{Projeto Pedagógico}

\section{OBJETIVOS}

O curso de Turismo do Centro Universitário da Cidade tem como objetivo primordial, qualificar recursos humanos para o mercado laboral, ou seja, capacitar os alunos de acordo com o perfil exigido pelo chamado Trade Turístico.

Neste aspecto, o curso está plenamente sintonizado como os avanços tecnológicos da atividade turística, levando-se em consideração as mudanças contínuas que ocorrem no mesmo.

Nossos professores são renomados profissionais de turismo, que são devidamente reciclados pela

UniverCidade, através de cursos de Pós-graduação na área de Docência Superior, para que tenham todas as ferramentas para ensinar o que vivenciam no dia-a-dia.

O Curso é eminentemente prático, sem esquecer a necessidade de uma formação sólida nas áreas de história, geografia, português, inglês, espanhol e marketing.

Apresenta, na sua estrutura curricular, as disciplinas técnicas como Transporte, Hospedagem,

Agenciamento, Eventos e Planejamento, já nos primeiros períodos, para que o aluno possa realmente sentir que está numa Organizar palestras, seminários, visitas técnicas, excursões nacionais e

internacionais, para, manter os nossos alunos

atualizados com as mais novas técnicas existentes no mercado.

\section{METODOLOGIA DO ENSINO}

As aulas do Curso de Turismo se apresentam divididas em três partes:

1- Aulas expositivas - onde o Professor através de sua vivência e da teoria existente sobre sua disciplina, apresenta utilizando transparências, vídeos, datashow as informações

relevantes para o aluno, visando a dotá-lo de uma capacidade analítica de entender o fenômeno turístico e sua repercussão.

2- Visitas externas para vivência "in loco", através inclusive de pequenos workshops, as informações recebidas em sala de aula.

3- Leitura de artigos e palestras fechadas para aprofundar as informações recebidas em sala de aula e criar uma perspectiva atual de atividade turística.

4- Utilização de laboratórios de informática, Agência da Cidade Cepetur e empresas conveniadas para colocar em prática o aprendizado.

A avaliação é feita através de provas escritas, trabalhos em grupo, participação em sala de aula e assiduidade. $O$ aluno também é convidado a se auto-avaliar, para que o processo seja participativo.

\section{Atividades Complementares Obrigatórias}

$$
\text { Grade curricular } 2003
$$

1) participar de pelo menos 2 laboratórios ao longo do curso.

2) participar de 2 visitas técnicas por período

3) participar de 1 seminário,pelo menos, por período e de todas as palestras em sua unidade.

4) planejar e organizar um evento.

5) planejar,comercializar e operar uma excursão,através da acadetur.

6) fazer o inventário turístico de um município ou outra atividade voltada ao desenvolvimento sustentável do município

7) Efetuar uma vivência prática dentro de um hotel. 8) Efetuar uma vivência prática dentro de uma transportadora 


\section{VISITAS TÉCNICAS}

\subsection{Conhecimento científico}

A visita técnica é um indicativo para o conhecimento científico, baseado na proposta de reconhecê-la como experimentação "que envolve a construção e aplicação de um teste modelo ou experimento, para simular o mundo real" ou observação "que consiste na observação direta do fenômeno físico para a coleta de dados", segundo McIntosch e Goeldner (in REJOWSKI, p.48), para se chegar ou fazer ciência, vez que a valorização dos dados e informações colhidos são obtidos através de uma estrutura programada e organizada, mas que a sua formatação não se prende a determinadas exigências finalísticas e sim medianas.

Desse modo, a previsão é o fator de busca ou delineador da visita técnica pois se constitui de análise e suposições construídas a partir do estabelecimento do planejamento de sua execução. Entendendo, a partir deste pressuposto, conforme Oliveira (1999) e Richardoson (1999), pode-se classificar as ações da visita técnica considerando os seguintes elementos como preponderantes para sua exata consecução:

a) O homem (ser humano)

- o que é o homem?

- como ele pode conhecer a realidade?

- como ele aceita e convive com a realidade?

- como a realidade se dá para o homem?

b) A natureza e a sociedade

- o que é a natureza?

- o que é a sociedade?

- como elas são concebidas para estudo?

- o que caracteriza sua existência (concreta, abstrata, virtual)

c) Produção do conhecimento

- como se estabelece o processo de produção do conhecimento? 
- quais os fatores de relevância entre o homem, natureza e sociedade?

- como se originam as idéias ou o saber da ciência?

- Como produzir o conhecimento a partir da observação?

Após o entendimento de tais elementos, faz-se necessário estabelecer um ordenamento dos procedimentos visando a regularidade e confirmação dos conteúdos construídos. Assim, pode-se entender as classificações das perspectivas epistemológicas, quais sejam:

a)Empirismo

- Supõe a primazia do objeto em relação ao sujeito;

- Conhecimento é produzido a partir da forma como a realidade se apresenta;

- Fonte principal está no objeto.

b)Racionalismo

- Supõe a primazia do sujeito ou da sua atividade em relação ao objeto;

- Razão ou capacidade humana de pensar, avaliar e estabelecer relações;

- Conhecimento da realidade a partir da causa situada na sua razão.

c)Interacionismo

- O conhecimento é produzido a partir da interação sujeito e objeto;

- Os produtos são resultados das inter-relações a partir das práticas sociais;

- Não se enquadra, nesse caso, a neutralidade científica.

4.2. Similaridade, segmentações turísticas e técnicas de pesquisa

Para que o entendimento sobre a importância da visita técnica como ferramenta de caráter curricular nos projetos pedagógicos das Instituições de Ensino Superior, é necessário, em primeiro lugar, distar quais as relações e similaridades desse tipo de atividade com algumas segmentações de turismo bem como a sua fundamentação técnica introdutória à pesquisa.

Os dados, informações e citações teóricas coletadas e que farão parte desta monografia serão apresentados dentro de uma seqüência que possibilitará 
fazer uma correlação dos assuntos desde a conceituação e a prática da pesquisa, da investigação científica, do propósito da introdução, realização e institucionalização da visita técnica nas IES até os comparativos e as similaridades dessa atividade com as segmentações turísticas reconhecidas.

\subsubsection{Pesquisa, o primeiro passo para o entendimento da visita técnica}

A estruturação de uma visita técnica, é importante para delinear sobre 0 reconhecimento do que vem a ser pesquisa e suas variáveis, ou, conforme afirma Dencker (2001, p.48), através de uma clara observação da realização da pesquisa em toda sua complexidade empírica, teórica e técnica, ou seja:

- atividade voltada a solução de problema;

- busca, indagação e investigação da realidade;

- elaboração do conhecimento ou de um conjunto de conhecimentos que nos ajudem na compreensão da realidade e orientem a ação, no ambiente da ciência;

- observação dos fatos, como base de toda investigação;

- torna-se científica a partir do momento que serve a um objetivo formulado de pesquisa.

Isto significa que a pesquisa não deve ser, também, vista de maneira rigorosa, ou como bem observa Demo (2000,p.128) "pesquisar não se restringe a seu aspecto sofisticado mais conhecido, que supõe domínio de instrumentações pouco acessíveis."

Algumas ações fornecem informações e dados mais consistentes e de real influência para os resultados que se propõe com a pesquisa. Diante disso, ao afirmar que a pesquisa é a atitude de aprender a aprender, Demo (2000, p.128/129) sugere que a pesquisa:

- significa diálogo crítico e criativo com a realidade, que resulta numa elaboração própria e na capacidade de intervenção;

- fundamenta o ensino e evita que este seja simples repasse copiado;

- aponta para a direção correta da aprendizagem, do "aprender a aprender";

- acolhe, na mesma dignidade, teoria e prática, de acordo com a realidade. 
A pesquisa, além de reforçar a ação orientativa do conceber a realidade, proporciona subsídios para um conhecimento mais amplo, além de fornecer elementos para a consecução, inclusive, de estudos de caso e, no âmbito acadêmico, "desenvolve a abrangência e o conteúdo do material disponível para educadores envolvidos no ensino de turismo e hospitalidade e assiste a evolução das áreas de estudo."(COOPER, 2001, p.113)

\subsubsection{Visita técnica: observação sistemática ou pesquisa de campo}

Ao propor o disciplinamento da visita técnica, seja como ferramenta curricular, extracurricular, complementar ou de extensão, não se deve deixar de analisar os princípios geradores da visita técnica, seja como observação sistemática, passeio como viagem técnica ou até pesquisa de campo. Tais orientações, voltadas, principalmente, para os discentes, proporcionam aos mesmos, entender o que fazer, como fazer e porque fazer a visita técnica, diante de uma preparação metodológica, na qual a execução de qualquer atividade prática seja caracterizada pela imprescindibilidade do conhecimento teórico mínimo, para que se possa constar que o desenvolvimento da visita seja produtivo, interessante e eficaz.

As dificuldades de se estabelecer padrões para a inserção da visita técnica como disciplina curricular, esbarram na construção de um planejamento eficaz, pela falta de estrutura das próprias IES, principalmente dos cursos de graduação, sobre o desenvolvimento e incentivo à pesquisa. Senão vejamos:

\footnotetext{
Na prática, é muito difícil planejar e executar uma visita de campo com sucesso. Isso requer pré-planejamento, conhecimento especializado de todos os aspectos pertinentes ao destino e a habilidade de abraçar toda informação relevante para os estudantes. (COOPER, 2001,p.151)
}

Este planejamento proposto para o disciplinamento da visita técnica nas grades (fluxos) curriculares pode ser admitido a partir de alguns pontos propostos por Veloso (2000, p.18/19) sobre as características fundamentais para a execução da visita técnica: 
- A base a verificação de cada detalhe do produto turístico, deve ser do mais simples serviço ou equipamento até o mais sofisticado, fantasiado e imperioso sonho do turista;

- A execução da visita técnica deve ser balisada pela formalidade, planejamento e muita observação;

- Nada pode escapar aos olhos do executante da visita técnica;

- O registro, as anotações devem ser prioritárias;

- O vislumbrar, o visualizar sem a seqüência da marcação didática, do apontamento escrito, fotográfico e até audiovisual, pode provocar falhas seríssimas na avaliação e análise do produto em visita, em estudo;

- A visita técnica não deve ser tratada como um simples passeio;

- Deve ser trabalhada dentro de um ritual de formalidades didáticas e pedagógicas e de elevado grau estatístico, geográfico e cultural;

- Observar, atentamente, a transformação, a distinção e a constante evolução e renovação do turismo, na sua essência mais pura - a imaginação (o sonho).

As recomendações constantes no livro Educando os educadores em Turismo: Manual de Educação em Turismo e Hospitalidade (COOPER, 2001), tem como enfoque as atividades a serem desenvolvidas que, ao ganharem contornos didáticos e estatísticos, altamente produtivos, permitem objetivar a visita técnica com mais propriedade e envolvimento dos estudantes, transmitindo e demonstrando os benefícios que ela pode produzir tanto em nível acadêmico, pessoal, profissional, social quanto coletivo.

Ao selecionar citações de interesse do discente, a posição favorável ao entendimento de que a visita técnica deve ser estabelecida como disciplina curricular, elenca elementos (dados e informações) importantes que podem influenciar, sobremaneira, no entendimento de tal proposição:

a) Com relação à prática e aos objetivos da visita técnica

- receber todas as informações dos educadores antes da visita

- o discente (e, por definição, o educador) deve ter uma idéia clara do propósito e dos objetivos da visita; 
- participação do discente em algum tipo de atividade, para focar suas mentes na atividade prática, garantindo que o tempo gasto no local de destino seja utilizado da melhor maneira possível;

- a antecipação do conhecimento quanto a toda complexidade do turismo é um risco muito grande se não for feita passo a passo;

b) Com relação à preparação, planejamento e execução

- conhecer, teoricamente, os tipos, as formas, as modalidades de turismo, as características, os aspectos, as normas, o disciplinamento turístico, enfim, toda a composição didática e formal do turismo;

- analisar os atrativos turísticos na sua especificidade, quanto a constituição, a consecução dos mesmos, manutenção e conservação, riscos e adversidades;

- envolver-se no conhecimento da preparação e organização da expressão turística (visitas, roteiros, planejamento, condicionamentos)

c) Com relação ao dia da visita

- o educador deve dar informações adicionais e oferecer ajuda aos alunos quando necessário;

- os detalhes são importantes porque vão determinar um bom ou mau entendimento por parte do aluno, das informações relevantes e da sua concentração nos aspectos-chave do exercício e no local de destino.

Complementado o entendimento sobre a maturidade da proposta de transformar a visita técnica como disciplina curricular, insere-se outro elemento importante para ser utilizado como referencial - o debate - construção interdisciplinar que propõe ampliar, com certeza, para uma produção pluri ou multidisciplinar de toda a complexidade conceitual, teórica e até empírica do turismo.

Essa essência é conceituada por Cooper (2001, p.151) e por Veloso (2000, p.59) que assim pode ser entendido:

- Sessão de debates após a visita é essencial para resolver importantes questões, discutir idéias e opiniões formadas pelos estudantes; 
- Permite o intercâmbio e assegura que aqueles estudantes que não foram totalmente beneficiados pela experiência tenham a chance de entender o que aconteceu de errado;

- Os educadores envolvidos nos debates devem desenvolver habilidades de pré-identificação de áreas que seriam causa de preocupação ou de má interpretação pelos estudantes.

- Que a cada visita num atrativo, o grupo estabeleça de 15 a 30 minutos, para um debate do que foi visto, ouvido, numa crítica sem longas discussões;

- Os professores que acompanham a visita técnica é que devem dirigir o processo de debate;

- As opiniões e as colocações dos alunos devem ser anotadas para, em sala de aula, desenvolver um diagnóstico dos pontos considerados de relevância para o aprendizado do futuro profssional de turismo;

- No caso de visita acima de 01 dia, pode substituir o debate a cada atrativo, para um debate no final do dia nas instalações do hotel em que se estiver hospedado ou em outro local de fácil concentração .

\subsubsection{A visita técnica dentro da visão de investigação científica}

A sistematização da visita técnica, partindo do princípio da observação até alcançar a condição de pesquisa, no âmbito da produção científica, deve ser a principal fonte de entendimento para conceituá-la e condicioná-la dentro dos elementos que permeiam e concebem as diretrizes curriculares. Assim sendo, ao conceituar, preliminarmente, como pesquisa de campo, deve-se considerar os três elementos que formam a base da investigação científica e que caracterizam o conhecimento como ciência: a teoria, o método e a técnica. (DENCKER, 2001, p.23).

Assim, como desenvolvimento de investigação científica, é imprescindível resgatar os ensinamentos teóricos, técnicos e científicos para demonstrar, com efetiva propriedade, a inquestionável importância da visita técnica dentro do contexto curricular dos cursos de turismo, principalmente, os de graduação. Não se pode 
conceber que a simples observação dos fatos seja caracterizada como conhecimento científico, deve-se configurar e estabelecer, conforme sugere Dencker (2001,p.23/24):

- uma técnica para registrar e quantificar os dados observados (dados do comportamento turístico), ordená-los e classificá-los;

- uma teoria que permita interpretar os dados, dotando-os de significação, ou, na falta desta, uma hipótese sobre o sentido da ação para se chegar à elaboração da teoria, baseada em leis científicas; $e$

- o método científico.

A questão da metodologia do turismo exige uma melhor compreensão das atividades teóricas (construídas em sala de aula) e as práticas (concebidas através de pesquisas e até de visitas ou viagens técnicas) para que as fontes mercadológicas de trabalho possam receber profissionais capacitados e qualificados, consagrados pela técnica, teórica e ciência e pelo influente entendimento prático do fazer, profissionalmente capacitado. Desse modo, a afirmação de Dencker sugere entender que o método do turismo segue a mesma dinâmica das ciências nas quais o turismo é objeto de estudo - numa visão bem ampla, de qualificação transdiciplinar até, e por isso:

Muitas são as disciplinas que tratam da questão do turismo e temos que admitir que ainda hoje o turismo não se constitui em um corpo de conhecimentos independentes, com dinâmica própria. (2001, p.27)

Por fim, há de se ajustar os indicativos do Ministério da Educação sobre os Conteúdos Curriculares (CES/CNE 0146/2002) que, não só permitem, como também, posicionam favoravelmente pela inserção da visita técnica com disciplina curricular, ao objetivá-la como parte integrante dos conteúdos teórico-práticos:

\footnotetext{
Conteúdos Curriculares

Os cursos de graduação em Turismo deverão contemplar, em seus projetos pedagógicos e em sua organização curricular, conteúdos que atendam aos seguintes eixos interligados de formação:

I-Conteúdos Básicos: estudos relacionados com os aspectos Sociológicos, Antropológicos, Históricos, Filosóficos, Geográficos, Culturais e Artísticos, que conformam as sociedades e suas diferentes culturas;

II-Conteúdos Específicos: estudos relacionados com a Teoria Geral do Turismo, Teoria da Informação e da Comunicação, estabelecendo ainda as relações do Turismo com a Administração, o Direito, a Economia, a Estatística e a Contabilidade, além do domínio de, pelo menos, uma língua estrangeira;

III-Conteúdos teórico-práticos: estudos localizados nos respectivos espaços de fluxo turístico, compreendendo visitas técnicas, inventário turístico, laboratórios de aprendizagem e de estágios.
} 
4.2.4.A visão docente e mercadológica sobre a visita técnica

Não obstante todos os argumentos citados anteriormente faz-se necessário inserir outros referenciais em que se vislumbra a importância da visita técnica para os cursos de turismo, hotelaria e hospitalidade que pode ser verificada em dois artigos publicados no site www.estudosturisticos.com.br, em que, o primeiro de Luciana Marques Lopes cujo título é A importância das visitas técnicas no curso de turismo e hotelaria (07/09/2003), vide Anexo D, apresenta a posição clara da necessidade da sua existência e aplicabilidade, do qual extraímos os seguintes argumentos:

-Em relação aos discentes:

É notável como os alunos absorvem muito mais o que aprendeu e compartilham com os colegas seu aprendizado e experiência.

-Em relação aos docentes:

De uma maneira interdisciplinar, os professores precisam estar inteirados e trabalharem conjuntamente para o melhor aproveitamento do ensino.

-Em relação ao mercado e à profissionalização:

As visitas técnicas, aplicadas de maneira correta e produtiva certamente contribuirá para o melhor desempenho dos alunos, fazendo com que eles possam vivenciar e entender o mercado em que estão inseridos e tornar-se profissionais conscientes e atentos para a realidade atual.

O outro artigo, de Marcelo Parreira Veloso, cujo título é Turismo Acadêmico uma nova segmentação (20/08/2003), vide Apêndice A, traduz não só a importância da visita técnica para o discente, o docente e a academia, mas, também, demonstra o grau de envolvimento da academia e o mercado, proporcionando, inclusive, a discussão sobre um novo nicho do mercado turístico - o Turismo Acadêmico.

Assim, convém apresentar alguns argumentos contidos nesse artigo que servem como parâmetros para comprovação da inquestionável necessidade da institucionalização da visita técnica como disciplina curricular.

-Em relação à produção da visita técnica

A produção da visita técnica amparada pelo ato de viajar e conhecer localidades e atrativos propõe considerá-la como um novo segmento, e que os estudos sobre tal argumentação, apesar de merecer uma maior dinâmica de pesquisa e análise, é importante ficar registrado que tal propositura tem fundamentos suficientes para, inclusive, situá-la com o título de Turismo Acadêmico. 
-Em relação ao princípio educativo

O Turismo Acadêmico chegou para ficar, com uma deferência, ele não só proporciona o turismo àqueles que dele participam, como também retira dele importantes e proveitosas lições.

Enfim, o Turismo Acadêmico "aprende, ensina, contribui e qualifica", e isso é ótimo para o turismo do $3^{\circ}$ milênio.

-Em relação ao mercado e à academia

Independente da necessidade dos instrumentos didáticos e pedagógicos que o caracterizam e diferenciam de outros segmentos turísticos, o "novo" nicho do mercado é a fórmula mais atual de se trabalhar o turismo, com vivacidade, qualificação e profissionalismo, ou seja, para cada "ação" acadêmica sempre haverá inúmeras "reações" acadêmicas, científicas, sociais, culturais, históricas, ambientais e mercadológicas - é a beleza incomensurável transposta pela sinergia do Turismo Acadêmico.

\subsection{Disciplina Curricular}

O desenvolvimento da pesquisa e os resultados obtidos prefaciam os argumentos a serem evocados em defesa da concepção da visita técnica como disciplina curricular.

Entressachando as considerações das IES diante das questões apresentadas (Vide Quadro 1 a 7) e as observações retiradas dos sites das IES selecionadas (vide Quadro 10 e 11), pode-se estabelecer algumas ilações de caráter preliminar e que, integradas aos indicativos de estudos antecedentes, permitirão propor, de maneira efusiva e inquestionável, a transformação ou transposição da visita técnica para os cursos superiores de turismo em disciplina efetivamente curricular. E é a partir desse ponto que faremos as considerações necessárias para a sua aceitabilidade.

\subsection{1-Antecedentes - indicativos de estudo}

Os instrumentos balizadores dessa monografia, constituem-se de:

Em primeiro lugar - $\mathrm{O}$ desenvolvimento de atividades e ações durante o período acadêmico (graduação) que permitiram a publicação de um livro sobre a atividade de pesquisa denominada visita técnica; 
Em segundo lugar - o projeto de graduação que teve como referência a pesquisa aplicada sobre "conhecer a dinâmica das visitas técnicas nos Cursos de Turismo e Hotelaria das IES de Goiânia", como elemento de confirmação, discussão e comprovação das questões enunciadas no livro; e

Em terceiro lugar - A necessidade de querer ou poder ajudar a mudar a retórica da atividade visita técnica instrumentalizada nas IES como atividade extracurricular, complementar ou de extensão, no sentido de introduzir conceituações e informações que possibilite a sua transformação em atividade de cunho interdisciplinar para a representação técnico-científica dentro da academia - fator agregador de valores

\subsection{2-Justificativa}

A apresentação da visita técnica como elemento de interdisciplinaridade é o que preceitua toda a estrutura do projeto de pesquisa - elemento desta monografia. Os referenciais do cotidiano consolidam a proposta de trabalho de preparação, planejamento e organização das visitas técnicas, tendo a mídia como um dos itens de discussão pela sua característica exploratória do fenômeno turístico além de propiciar a fundamentação da sistemática de observação e do ponto de partida para a pesquisa científica.

Outro ponto importante é sobre o enfoque das representações que permitem estabelecer o vínculo entre as peculiaridades, objetivos e finalidade das IES com os princípios que balizam a visita técnica, tomando-se por base os conteúdos didáticos, metodológicos e empíricos, utilizados nos cursos de turismo e hotelaria, já demonstrados exaustivamente neste projeto. Reforçando, ainda, os argumentos comparativos, há de se inserir a interpretação sobre os cruzamentos das informações, dados e conceitos adquiridos e absorvidos nas salas de aula (disciplinas ministradas) e nos deslocamentos realizados para a prática da visita técnica. 
Argumentos e relações contigenciadas pelas estruturas acadêmicas que formatam as grades curriculares dos cursos de turismo das Instituições de Ensino Superior-IES, predispõem o desenvolvimento da atividade denominada visita técnica de maneira menos como "pesquisa ou observação sistemática" e muito mais como atividade complementar ou até de extensão, para justificar um sentido ao "encargo" do curso, ou seja, sem a verdadeira especificidade do próprio sinônimo existente para a visita técnica.

Partindo desse ponto, a proposta da "pesquisa" ou melhor representada como "observação sistemática" sobre a importância da visita técnica como referencial à interdisciplinaridade vem concretizar e demonstrar a crítica citada acima, pela insuficiência de ferramentas que possibilitem nortear a visita técnica como elemento mediano e não como elemento finalístico de uma pesquisa (na sua plenitude), construindo assim, um questionamento sobre a sua real e efetiva função interdisciplinar ou integradora de conteúdos disciplinares.

A visita técnica é um instrumento de auxílio à produção científica, construído em "pílulas" de entendimentos teóricos e técnicos absorvidos e implementados através da absorção e reformulação dos conteúdos constantes das disciplinas desenvolvidas, a cada semestre ou a cada ano, nas IES.

No primeiro momento ou na primeira visita técnica devem ser utilizados todos os instrumentos e elementos apresentados por todas as disciplinas como referenciais para a execução do trabalho de pesquisa denominada visita técnica. Nos momentos seguintes ou na visita técnica subseqüentes, são acrescidos ou agregados as novas ferramentas teóricas e técnicas das novas disciplinas.

A visita técnica, de maneira "providencial" passa a ser o canal interdisciplinar de execução prática do aprendizado técnico ou teórico e, evidentemente, o referencial para posteriores pesquisas de produção 
científica. Ela não deve ser caracterizada como pesquisa de campo, pela sua peculiaridade mediana, onde a representação é o seu quesito de observação sistemática, enquanto a pesquisa de campo tem como fundamento e instrumento finalístico, o resultado científico, sem a preocupação com o construir e agregar referenciais em etapas posteriores. Seria interessante entender que a visita técnica tem como característica a produção interdisciplinar do aprendizado em sala, pois a sua condição é temporária, sem aprofundamentos científicos; é visual, configurada em apontamento, dados, informações e registros do momento concebido e sua utilidade é exercitar o cruzamento dos ensinamentos perfilados pelas disciplinas do curso, motivando, dessa maneira, a relação técnica e prática, sem a concretização do diagnóstico, mas sim do relatório onde se expressa o crescimento pessoal e profissional do acadêmico, do discente.

\subsection{3-Condicionantes - fundamentações para análise}

\section{Caracterizações e questionamentos}

Parte-se do pressuposto de que a visita técnica não é ou não tem sido caracterizada como disciplina curricular e tampouco extracurricular, dentro dos projetos pedagógicos das Instituições de Ensino Superior. Tal postura não é peculiar das IES e sim das próprias diretrizes traçadas e mensuradas pelo Ministério da Educação que, apesar de posicionar a visita técnica como uma atividade constante nos conteúdos curriculares, não conjuga a sua interdisciplinaridade, inserindo apenas como um fator agregador aos valores que devem compor o projeto pedagógico dos cursos de turismo de cada Instituição de Ensino Superior.

O tratamento dispensado tanto pelos Cursos de Graduação em Turismo e Hotelaria como pelos Cursos de Pós-graduação, também, em turismo, deixa muito a desejar, pois apesar de se considerar a visita técnica como uma ferramenta, um instrumento de pesquisa, pouco se tem feito de concreto para mudar esta postura arcaica de "planejar viagem técnica" aos estudantes sem nenhum embasamento, minimamente, científico, onde o passeio é a aceitação mais clara e evidente a ser concebida pelos acadêmicos ou discentes. 
Os projetos pedagógicos, as diretrizes curriculares e a interdisciplinaridade, são elementos que devem, evidentemente, ser os norteadores da inclusão da visita técnica, como disciplina curricular, balizada nos princípios do cientificismo da pesquisa e na consecução ideal da produção do turismo profissional, ético e verdadeiramente seguro.

Portanto, faz-se necessário os seguintes questionamentos:

- Por quê as Instituições de Ensino Superior não inserem nos Projetos Pedagógicos dos seus Cursos de Turismo a visita técnica como disciplina curricular?

- Por quê o Ministério da Educação não qualifica a importância da visita técnica como instrumento primordial da produção científica, traduzida em exigência de disciplinar a visita técnica, pela peculiaridade das IES, que é o incentivo à pesquisa, a investigação científica.

\section{Estrutura e literatura turística sobre visita técnica}

Toda a análise sobre a estruturação da visita técnica fica um tanto quanto comprometida, pela falta de literatura e produção científica que trata sobre o assunto. Entretanto, busca-se em ações e atividades similares para que se possa posicionar e nortear o projeto.

A visita técnica pode ser considerada uma pesquisa?

Esta interrogação mostra que o campo referencial de pesquisa é amplo, mas, quando se volta para a prática da pesquisa em turismo, a fragilidade da literatura é visível. Desse modo, alguns autores foram e serão os referenciais norteadores do projeto de pesquisa, diante do principal documento a ser trabalhado que são as "Diretrizes Curriculares" do Ministério da Educação (CES/CNE 0146/2002) - ponto de partida para a discussão e problemática a que se propõe este projeto.

A bibliografia utilizada, por ora, fixa-se em:

No livro Métodos e técnicas de pesquisa em turismo (Futura: São Paulo, 2001) de autoria de Ada de Freitas Maneti Dencker, como referencial mais completo sobre pesquisa em turismo. 
No livro Educando os educadores em Turismo: Manual de Educação em Turismo e Hospitalidade (Roca: São Paulo, 2001), de Chris Cooper e outros, no que se refere à discussão sobre a visita de campo, o disciplinar tal atividade, tomando-se por base a própria academia.

No livro de Marcelo Parreira Veloso, cujo título Visita Técnica - uma investigação acadêmica (Kelps: Goiânia, 2000) é a demonstração mais clara da discussão sobre a prática da visita técnica, e que, além de se configurar como documento mestre de estudo, é o princípio gerador de um projeto que vem se estendendo desde antes da graduação do autor deste projeto.

No projeto de Graduação (TCC) do Curso de Turismo pela Faculdade Cambury de Goiânia, Goiás, desenvolvido pelo proponente deste projeto, cujo tema é A dinâmica das visita técnicas nos cursos de turismo das IES de Goiânia, no período de 1998 a 2001.

\subsection{4-Proposta curricular}

A estrutura da visita técnica para constar na grade (fluxo) curricular das IES tem por base a construção a cada período anual e merece uma análise mais aprofundada sobre as características e ênfase existente em cada curso de turismo das instituições de ensino superior.

Os dados iniciais, para ordenamento e classificação curricular, devem ser observadas as considerações constantes nas diretrizes curriculares do Ministério de Educação, priorizados para que a configuração dos mesmos balize a proposta de "disciplina curricular".

Quaisquer outros elementos ou dados podem ser acolhidos e mensurados, partindo do pressuposto de que a visita técnica tem a sua instrumentalização prática a partir de dados técnicos e teóricos. Assim, não fica comprometida a interdisciplinaridade e a interação dos conhecimentos e aprendizados. 
$\mathrm{Na}$ abordagem do conteúdo e na metodologia de ensino da disciplina curricular proposta, precisa haver um esforço do corpo docente de que os métodos e procedimentos de ensino e aprendizagem correspondam ao que se espera que os discentes realizem quando estiverem atuando nas suas atividades profissionais.

\section{$\underline{1^{\circ} \text { Ano }}$}

- Conceitos e referenciais teóricos sobre observação sistemática, pesquisa de campo, visita técnica;

- diferenças e similaridades das atividades da visita técnica, observação sistemática e pesquisa de campo;

- aprender fazer apontamentos, fazer registro;

- relação da visita com os conteúdos e práticas inerentes às disciplinas do $1^{\circ}$ ano.

\section{$2^{\circ}$ Ano}

- Relação/conhecimento sobre tipos, formas, modalidades e segmentos do turismo para a utilização quando da realização da visita técnica;

- criação de equipes/comissões para desenvolvimento das visitas;

- conhecimento sobre meios de hospedagem, transportes, agências, atrativos, produtos turísticos;

- relação da visita com os conteúdos e práticas inerentes às disciplinas do $2^{\circ}$ ano.

\section{$\underline{3^{\circ} \text { Ano }}$}

- Organização/preparação da visita técnica conforme dados teóricos por parte dos estudantes sob orientação de professores;

- criação de visitas técnicas (estudos de casos);

- estruturação de roteiros para a execução de visitas técnicas;

- relação da visita com os conteúdos e práticas inerentes às disciplinas do $3^{\circ}$ ano. 


\section{$\underline{4^{\circ} \text { Ano }}$}

- A prática da visita técnica como enfoque/indicativo para o TCC, podendo ser instrumento do projeto (pesquisa aplicada, projeto experimental, monografia, etc...);

- relação da visita técnica com os conteúdos e práticas inerentes às disciplinas de todos os períodos/anos do curso.

Diante da exposição da estrutura curricular, apresentamos abaixo uma proposta do Plano de Ensino/ementa da disciplina curricular denominada "Visita Técnica". 


\section{INSTITUIÇÃO DE ENSINO SUPERIOR \\ PLANO DE ENSINO}

INSTITUTO: Ciências Humanas

CURSO: Turismo

SÉRIE/CICLO: $1^{\circ}$ ao $4^{\circ}$ ano

DISCIPLINA: Visita Técnica

CARGA HORÁRIA: 2 h/aula/semana

$N^{\circ}$ ESTUDANTES/POR AULA: até 50

PROFESSOR: Bacharel em Turismo com especialização em pesquisa de campo ou profissional com especialização em planejamento turístico e pesquisa de campo.

\section{I - ANTECEDENTES E CONDICIONANTES}

Os requisitos e os aspectos balizadores da proposta de estabelecimento e inserção da atividade denominada "visita técnica" produzida, atualmente, pelos discentes nos cursos de turismo e hotelaria da Instituições de Ensino Superior, como disciplina curricular em todos os estágios, períodos ou ciclos nesses cursos, podem ser analisados a partir de três referenciais construídos pela pesquisa, literatura e análise disciplinar:

O primeiro referencial trata do desenvolvimento de atividades e ações a partir da publicação do livro sobre a atividade de pesquisa denominada Visita técnica uma investigação acadêmica;

O segundo referencial é complementar ao primeiro, pois trata-se de um projeto de graduação que teve como "referência" a pesquisa aplicada sobre Conhecer a dinâmica das visitas técnicas nos Cursos de Turismo e Hotelaria das IES de Goiânia, como elemento de confirmação, discussão e comprovação das questões enunciadas no livro acima citado;

O terceiro referencial trata do acompanhamento com base nos referenciais citados anteriormente, onde se estabelecem parâmetros de análise quanto à retórica da atividade visita técnica instrumentalizada nas IES como atividade extracurricular, complementar ou de extensão, buscando viabilizar a introdução de conceituações e informações que possibilite a sua transformação em atividade de cunho interdisciplinar (disciplina curricular) para a representação técnico-científica dentro da academia - fator agregador de valores. 
Assim, diante dos "antecedentes" apresentados, enumeram-se dois pontos "condicionantes" para a proposta de implementação da disciplina curricular visita técnica.

1. Agregar nos projetos pedagógicos a possibilidade de delinear a visita técnica como atividade curricular, a partir da inclusão da mesma, através de métodos interdisciplinares;

2. Inserir a Visita Técnica como disciplina curricular nas grades dos cursos de turismo, hotelaria e hospitalidade das Instituições de Ensino Superior, no sentido de proporcionar aos estudantes a viabilidade da inter-relação entre a teoria e a prática do turismo;

\section{II - OBJETIVO}

1. Conceituar e descrever as teorias e técnicas de pesquisa em turismo, hotelaria e hospitalidade, com finalidades de promover a aplicação das mesmas correlacionando com as teorias e técnicas do turismo, análise, estudo e aplicação na prática;

2. Orientar os alunos para o levantamento de dados e pesquisa em relação às disciplina ensinadas durante o curso, como base interdisciplinar;

3. Construir banco de dados e audiovisuais de todas as visitas técnicas realizadas, no sentido de nortear e projetar estudos de caso, além de fornecer elementos referenciais para projetos de conclusão de curso.

4. Reforçar os argumentos comparativos e as interpretações sobre os cruzamentos das informações, dados e conceitos adquiridos e absorvidos nas salas de aula (disciplinas ministradas) e nos deslocamentos realizados para a prática da visita técnica;

5. Fundamentar a análise dos atrativos turísticos na sua especificidade, quanto a constituição e consecução dos mesmos, considerando os elementos sobre a manutenção, conservação, riscos e adversidades;

6. Desenvolver técnicas para registro e quantificação dos dados observados (dados do comportamento turístico), ordenando e classificando-os para inserção nos relatórios e nos projetos a serem confeccionados durante o curso; 


\section{III- CONTEÚDO PROGRAMÁTICO (organização seqüencial dos conteúdos)}

\section{$\underline{1^{\circ} \text { Ano }}$}

- Apresentar conceitos e referenciais teóricos sobre observação sistemática, pesquisa de campo, visita técnica;

- Demonstrar diferenças e similaridades das atividades da visita técnica, observação sistemática e pesquisa de campo;

- Instruir e instrumentalizar os discentes sobre como fazer apontamentos, registros e relatórios decorrentes das visitas às localidades e atrativos;

-Propor e promover a realização de City-tour na cidade/localidade onde se situa as IES, como primeiro indicador de perspectiva turística;

- Delinear e compatibilizar a relação da visita técnica com os conteúdos das disciplinas do $1^{\circ}$ ano.

\section{$\underline{2}^{\circ}$ Ano}

- Relacionar os conhecimento sobre tipos, formas, modalidades e segmentos do turismo para a utilização quando da realização da visita técnica;

- Propor a criação de equipes e ou comissões de estudantes para ordenamento das visitas técnicas de conformidade com as técnicas e metodologias adequadas e correspondentes ao planejamento turístico;

-Promover o conhecimento sobre meios de hospedagem, transportes, agências, atrativos, produtos turísticos, no sentido de que os apontamentos e registros sejam verificados e diagnosticados quando da realização/execução da visita técnica, confrontando a teoria e a prática;

- Realizar as atividades de campo em conformidade com a estrutura definida para a sua consecução - estratégias de trabalho

- Desenvolver ações que permitam a utilização e a relação da visita com os conteúdos das disciplinas do $2^{\circ}$ ano.

\section{Ano}

- Definir a organização e preparação da visita técnica conforme dados teóricos por parte dos estudantes sob orientação de professores, através da elaboração e planejamento de projeto;

- Proporcionar a criação e realização de visitas técnicas (estudos de casos) tendo como parâmetros as visitas técnicas realizadas nos anos anteriores; 
- Estruturar roteiros para a execução de visitas técnicas, de acordo com a viabilidade de caráter profissionalizante;

- Promover o envolvimento e a conjugação das ações tendo como referenciais com os conteúdos das disciplinas do $3^{\circ}$ ano, para a consecução das visitas técnicas;

\section{$\underline{4^{\circ} \text { Ano }}$}

- Estabelecer a prática da visita técnica como enfoque e indicativo para os Trabalhos de Conclusão de Curso-TCC, podendo ser instrumento de projetos finalísticos (pesquisa aplicada, projeto experimental, etc...);

- Promover a inter-relação dos conteúdos das disciplinas de todos os períodos/anos do curso.

\section{IV - ESTRATÉGIA DE TRABALHO / TRABALHOS DIDÁTICOS}

- Organização de visitas a localidades e atrativos, conforme calendário preparado e previamente estabelecido pela IES;

- Aulas expositivas e interativas;

- Palestras, cases, oficinas e seminários

- Pesquisas, confecções de artigos, leitura de textos, discussões

- Formação de comissões entre discentes, sob coordenação e orientação do professor da disciplina, com distribuição de tarefas para ordenamento, planejamento e execução da visita técnica;

- Criação de banco de dados e audiovisuais;

- Apresentações de trabalhos, relatórios e projetos.

\section{V - PROCESSO DE AVALIAÇÃO DE APRENDIZAGEM}

- Participação nas comissões e nas visitas técnicas;

- Confecção de relatórios e apresentações de trabalhos e projetos;

- Seminários, oficinas e cases;

- Trabalhos interdisciplinares;

- Provas com avaliação descritiva das visitas realizadas e ou construídas;

\section{VI - RECURSOS E MATERIAL DE APOIO}

- Livros sobre visita técnica, pesquisa de campo, observação sistemática, metodologia de pesquisa em turismo;

- Revistas, sites, jornais, artigos e textos; 
- CD-rom, filmes, cartazes

- TV, vídeo, data-show, retroprojetor, slides, flip-chart, painéis

- Microcomputador, impressora, Internet, scaner, gravadora de CD, copiadora

- Máquina fotográfica, filmadora

- Banco de dados e informações construído pela instituição para armazenamento, arquivo e pesquisa de visitas técnicas realizadas.

VII. AÇÕES DE CARÁTER DIDÁTICO E PEDAGÓGICO, PARA VIABILIZAÇÃO DA INSERÇÃO DA DISCIPLINA “VISITA TÉCNICA" NAS GRADES CURRICULARES

- Levantar todos os dados e informações contidas nas Diretrizes Curriculares para os Cursos de Turismo das IES delineadas pelo Ministério da Educação, sobre visita técnica;

VIII - FONTES DE INFORMAÇÕES E RECURSOS BIBLIOGRÁFICOS

ANDRADE, José Vicente. Turismo, fundamentos e dimensões. São Paulo, Ática, 1995.

BARRETO, Margaritta. Manual de iniciação ao estudo do turismo. 4 ed., São Paulo: Papirus, 1998.

BISSOLI, Maria Ângela Marque Ambrizi. Planejamento turístico municipal com suporte em sistemas de informação. São Paulo: Futura, 1999.

CARVALHO, Alex Moreira...(et al.). Orientações para normalização de trabalhos acadêmicos. São Paulo: O Nome da Rosa, 2000.

CYRANKA, Lúcia Furtado de Mendonça, SOUZA, Vânia Pinheiro de. Aprendendo metodologia científica: uma orientação para os alunos de graduação. $6^{\mathrm{a}}$ ed. rev. e atual. Juiz de Fora: EDUFJF, 2000

COOPER, Chris e outros. Educando os educadores em Turismo: Manual de Educação em Turismo e Hospitalidade. São Paulo: Roca, 2001.

DEMO, Pedro. Educação e Qualidade . 5a ed. São Paulo: Papirus, 2000.

DENCKER, Ada de Freitas Maneti. Métodos e Técnicas de pesquisa em turismo. 5 ed. São Paulo: Futura, 2001.

RUDIO, Franz Vitor. Introdução ao projeto de pesquisa científica. Petrópolis: Vozes, 2002.

VELOSO, Marcelo Parreira. Turismo simples e eficiente. São Paulo, Roca, 2003. . Visita técnica - uma investigação acadêmica. Goiânia, Kelps, 2000. 


\section{CONSIDERAÇÕES FINAIS}

A visita técnica encarada no contexto de um processo de formação deve ser estabelecida e institucionalizada para ser concebida nos projetos pedagógicos dos cursos superiores de turismo, hotelaria e hospitalidade - esta é a defesa mais clara, objetiva e autêntica da proposta constante neste projeto.

É importante ressaltar que:

1. Apesar da apresentação e da aceitação, em princípio, como marco inicial de um projeto, não se espera que a visita técnica seja ou continue sendo trabalhada como atividade complementar ou extracurricular, em função dos dados apresentados em que se verifica a sua relevância conceitual, programática e metodológica. Para tanto recorremos a Libâneo que propõe o seguinte entendimento:

"A questão dos métodos se subordina à dos conteúdos: se o objetivo é privilegiar a aquisição do saber, e de um saber vinculado às realidades sociais, é preciso que os métodos favoreçam a correspondência dos conteúdos com os interesses dos alunos, e que estes possam reconhecer nos conteúdos o auxílio ao seu esforço de compreensão da realidade (prática social)". (1985, p.40)

2. A interdisciplinaridade deve ser entendida como elemento norteador da construção da visita técnica, mas não o elemento que traduz ou propõe a atividade em uma ou outra disciplina. Assim a visita técnica não deve ser entendida e trabalhada simplesmente como atividade e sim como "princípio disciplinar" ou "indicativo para o conhecimento científico".

Nesse ponto, recorremos à Regina Bodmiak Pereira, que de maneira positiva, traduz a seguinte consideração sobre a interdisciplinaridade:

"É frágil, é inconsistente, é reducionista, por exemplo, a perspectiva de considerar a interdisciplinaridade apenas e tão- somente com base na mera integração entre diferentes especialistas, com base na mera integração de conteúdos de diferentes disciplinas". (in MARIN, 2000, p.330) 
3. A visita técnica deve receber em sua ementa os elementos já propostos nesta monografia. Pode-se tomar, também, por referência, algumas ações desenvolvidas por determinadas instituições em que a visita técnica é trabalhada de maneira quase similar a este projeto, verificando assim que os dados e referenciais inseridos neste projeto serão evidentemente aceitos pelas Instituições de Ensino Superior que tem como base a profissionalização do discente, seja para o mercado, para a pesquisa, docência ou outra atividade concernente às ênfases ou especialidades da graduação.

4. Por fim, consideramos salutar o registro do valor pessoal e profissional propiciado pela visita técnica, a partir das suas principais características em prol do discente, do docente, da academia e do mercado:

- Organização e ordenamento de atividades;

- Formulação de ações;

- Trabalho em equipe;

- Seqüência de tarefas;

- Definição de objetivos;

- Enfoque no planejamento;

- Preparação para a pesquisa;

- Reconhecimento e identificação de produtos e serviços - link;

- Entendimento de normas e legislação;

- Compreensão sobre questionário, entrevista, captação e catalogação de dados;

- Construção de produtos (perfil, cenário, atividades);

- Vivência e interpretação de dados, informações e valores.

Assim sendo, o que se espera são transformações do sistema educacional, mesmo compreendendo que as particularidades dos grupos dirigentes do processo da sociedade e do ensino superior devam ser modificadas, diferenciadas ou questionadas, entendendo que, se de um lado há a emancipação do mercado educacional com a proliferação de instituições privadas sem o foco integrativo da pesquisa como base essencial do processo educativo, de outro lado, há de se desenvolver um reestudo dos elementos educacionais em 
que as "condições dos docentes" sejam valorizadas, principalmente pela qualificação das suas propostas e atuações educacionais, pedagógicas e didáticas, bem como das suas funções humanas e, acima de tudo, edificadoras e indispensáveis para a formação de valores sociais, culturais, científicos e políticos. Isto é: oportunizar que a visita técnica seja o marco inicial da proposta construtivista, evidentemente não exclusivista, de um novo sistema educacional para o turismo e de uma revolução na atividade docente com qualidade de vida e responsabilidade profissional.

Verifica-se, portanto, a caracterização de um processo de formação, cuja função é permitir uma avaliação continuada e integrada, pontuando periodicamente todo o conhecimento adquirido e partilhado, possibilitando vislumbrar resultados altamente vantajosos: em relação à própria concepção do ensino superior; às oportunidades disponibilizadas aos docentes sobre a investigação científica e, evidentemente, para a melhoria da sua capacitação como educador e em relação ao profissionalismo e qualificação do discente. 


\section{REFERÊNCIAS BIBLIOGRÁFICAS}

ALVARENGA, Maria Amália F.P., COUTO ROSA, Maria Virgínia F.P. Apontamentos de metodologia para a ciência e técnicas de redação científica. Porto Alegre: Sérgio Antônio Fabris (Editor), 1999.

ANDRADE, José Vicente. Turismo, fundamentos e dimensões. São Paulo, Ática, 1995.

BARRETO, Margaritta. Manual de iniciação ao estudo do turismo. 4 ed., São Paulo: Papirus, 1998.

BISSOLI, Maria Ângela Marque Ambrizi. Planejamento turístico municipal com suporte em sistemas de informação. São Paulo: Futura, 1999.

BRAGA, José Luiz e Maria Regina CALAZANS. Comunicação e Educação questões delicadas na interface. São Paulo: Ed. Hacker, 2001.

CARVALHO, Alex Moreira...(et al.). Orientações para normalização de trabalhos acadêmicos. São Paulo: O Nome da Rosa, 2000.

CARVALHO, Paulo Jorge. Condução de grupos no turismo. São Paulo: Chronos, 2002.

CYRANKA, Lúcia Furtado de Mendonça, SOUZA, Vânia Pinheiro de. Aprendendo metodologia científica: uma orientação para os alunos de graduação. $6^{a}$ ed. rev. e atual. Juiz de Fora: EDUFJF, 2000

COOPER, Chris e outros. Educando os educadores em Turismo: Manual de Educação em Turismo e Hospitalidade. São Paulo: Roca, 2001.

DEMO, Pedro. Desafios modernos de educação. Petrópolis: Vozes, 1993. . Educação e Qualidade . 5a ed. São Paulo: Papirus, 2000.

DENCKER, Ada de Freitas Maneti. Métodos e Técnicas de pesquisa em turismo. 5 ed. São Paulo: Futura, 2001.

FILÁRTIGA, Virgínia e TATAGIBA, Maria Carmem. Vivendo e aprendendo com grupos: uma metodologia construtiva de dinâmica de grupos. Rio deJaneiro: DP\&A, 2001.

FREIRE, Paulo. Pedagogia da autonomia: saberes necessários à prática educativa. São Paulo: Paz e Terra, 1996.

LIBÂNEO, José Carlos. Democratização da escola pública: a pedagogia críticosocial dos conteúdos. São Paulo: Loyola, 1985.

MARIN, A.Junqueira (org.). Educação Continuada. São Paulo: Papirus, 2000.

OLIVEIRA, Sílvio Luiz de, 1943 - Tratado de metodologia científica: projetos de pesquisa, TGI, TCC, monografias, dissertações e teses. Sílvio Luiz de Oliveira, 
revisão Maria Aparecida Bessana. São Paulo: Pioneira Thomson Learning, 2001. $3^{\mathrm{a}}$ reimpr da $2^{\mathrm{a}}$ ed. De 1999.

ORGANIZAÇÃO MUNDIAL DO TURISMO-OMT, Introdução ao Turismo, São Paulo: Roca, 2001.

REJOWSKI, Mirian. Turismo e pesquisa científica. 5a ed. São Paulo: Papirus, 2001.

RICHARDSON, Roberto Jarry. Pesquisa social: métodos e técnicas / Roberto Jarry Richardson; colaboradores José Augusto de Souza Peres... São Paulo:Atlas, 1999

RUDIO, Franz Victor. Introdução ao projeto de pesquisa científica. $30^{\mathrm{a}}$ ed., Petrópolis: Vozes, 2002.

VELOSO, Marcelo Parreira. Visita técnica - uma investigação acadêmica. Goiânia, Kelps, 2000. , Turismo simples e eficiente, São Paulo: Roca, 2003.

Outras fontes:

Monografia:

VELOSO, Marcelo P. A dinâmica das visitas técnicas das IES de Goiânia. Monografia de graduação - Curso de Turismo da Faculdade Cambury, Goiânia, 2002.

Sites:

http:/www.abbtur.com.br

http:/www.canaltur.com.br

http:/www.embratur.gov.br

http:/www.estudosturisticos.com.br

http:/www.mec.gov.br

http:/www.turismo.gov.br

http:/www.turismologia.com.br

Legislação Federal:

Brasil, Lei 9.394/96 de dezembro de 1996 (Lei de Diretrizes Bases-LDB/96)

CD-Rom:

ENCONTRO ESTADUAL DE DIDÁTICA E PRÁTICAS DE ENSINOEDIPE(I:2003:Goiânia) Anais/Resumos Expandidos do I Encontro estadual de didática e práticas de ensino[CD-ROM]. Goiânia:2003 - 1 CD-ROM 


\section{APÊNDICES}




\section{Apêndice A - Artigo: Turismo Acadêmico}

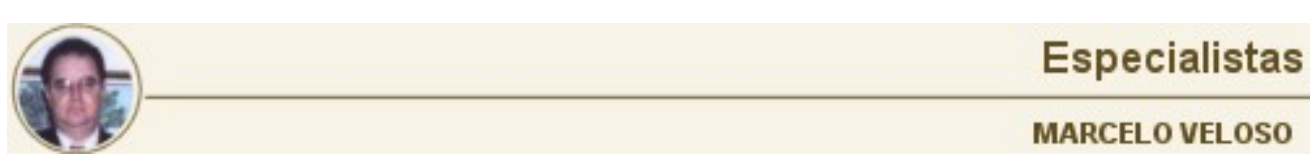

Marcelo Veloso é professor universitário na área de Turismo, consultor e escritor Especialistas | Menu | Perfil | Voltar

\section{Turismo Acadêmico - uma nova segmentação}

A nova modalidade ou segmento do turismo que tem conseguido distanciar de tudo isso é o que proponho chamar de Turismo Acadêmico, que difere um pouco do turismo cultural, estudantil e até do pedagógico, vez que este é uma mescla fantástica de passeio e trabalho, de lazer e conhecimento, de admiração e profissionalismo, de envolvimento e entretenimento, de teoria e prática.

\section{O Mercado atual e a produção do achismo}

O produto turístico, fatia importante do mercado econômico mundial tem proporcionado nos últimos anos, no Brasil, a muitos estudiosos e profissionais do turismo, conhecer e citar a implantação de segmentações, tipos, formas e tendências que, às vezes, escapam aos dedos, contar e contar, tanta diversificação, contributiva e interessante, porém pouco ou quase nada qualificada.

De outro lado os faz-faz que tudo-faz (achistas de toda ordem) pelo dito bem da economia e das finanças, tem produzido estonteantes e maléficas ações e atividades que arrastam visitantes, excursionistas e turistas a lugares sem nenhuma estrutura, conforto e segurança, seja através de serviços de transportes clandestinos, por estradas mal cuidadas, mal sinalizadas e intrafegáveis, seja através de visitas a atrativos sem nenhum equipamento e serviço adequado e inexistência de infra-estrutura básica.

E olha que é por este Brasil afora!

Por incrível que pareça, muitas e muitas autoridades municipais, estaduais e federais tem conhecimento e, simplesmente, fecham os olhos ou fingem desconhecer os problemas.

Precisamos dar um basta. E logo!

\section{Surge um novo segmento}

A nova modalidade ou segmento do turismo que tem conseguido distanciar de tudo isso é o que proponho chamar de Turismo Acadêmico, que difere um pouco do turismo cultural, estudantil e até do pedagógico, vez que este é uma mescla fantástica de passeio e trabalho, de lazer e conhecimento, de admiração e profissionalismo, de envolvimento e entretenimento, de teoria e prática. São as famosas e já disseminadas Visitas Técnicas, de estudantes acompanhados de professores, das áreas de turismo, hotelaria, geografia, história entre tantas outras. Mas queremos fazer uma ressalva muito particular, neste momento, sobre as visitas técnicas realizadas na área de turismo, hotelaria e hospitalidade, onde há aí uma preocupação com toda a estrutura da produção turística que inclui a preparação, a escolha do local, o transporte, alimentação, hospedagem, serviços e equipamentos, guias, infra-estrutura, ou seja, todo o complexo que passa a ser fonte de utilização, estudo, pesquisa, estatística e avaliação.

Por se tratar de um trabalho tão importante para a qualidade do turismo é que chamo a atenção, principalmente, do trade e dos organismos oficiais, pois do resultado desse Turismo Acadêmico, das Visitas Técnicas, é que nós teremos, com certeza, uma melhoria substancial nos serviços, equipamentos e na estrutura geral do turismo, vez que são feitas pesquisas (leia-se observações sistemáticas ou pré-pesquisas), análises, diagnósticos e avaliações que muito importam, não só aos estudantes para agregarem conhecimentos e valores profissionais, mas para as instituições de ensino superior, para os atrativos, para os organismos oficiais e ao trade, pois terão uma crítica responsável, séria e altamente científica, que servirá de base para as mudanças, para as alterações e, conseqüentemente, para uma considerável qualidade da oferta turística.

\section{Um movimento crescente, crescendo, sem fim}

Para se ter uma idéia da grandiosidade deste tipo de turismo, basta fazermos uma pequena projeção, empírica até, se considerarmos $50 \%$ das universidades e faculdades, só dos cursos de turismo e hotelaria, a partir do número estimado de 300 (trezentas) instituições que estão com acadêmicos formando ou em formação, e que todas as turmas (entende-se 8 turmas cada curso em apenas 01 turno) façam 01 visita técnica por semestre, onde 40 a 50 estudantes participam diretamente, há de se dimensionar uma média de 1.200 visitas técnicas semestrais, provocando, portanto, um deslocamento médio de 50.000 pessoas, entre estudantes e professores, para inúmeras localidades turísticas e, melhor ainda, estas visitas técnicas, em sua maioria, são realizadas durante a baixa temporada. Mesmo que estes dados não sejam oficiais, pois a maioria das faculdades e universidades ainda não disponibilizam tais informações, com tamanha precisão, podemos considerar o Turismo Acadêmico como um "novo" nicho do mercado. São visitas de curta, média e até de longa distância, onde há todo um envolvimento e movimento dos serviços de transporte, alimentação, hospedagem, guias, comércio que, conjugados com a baixa temporada, transformam este segmento numa fatia muito apetitosa para ser consumida pelo turismo interno.

Os referenciais desse segmento podem ser caracterizados pela constância das viagens e do crescente número de turistas, a partir das considerações sobre o aumento considerável de cursos de turismo e hotelaria no Brasil. E, por outro lado, há de se inserir outros tantos números de viagens envolvendo acadêmicos de outros cursos onde a visita técnica é produzida com fins de até de pesquisa. 
Teoria e prática $X$ Segmentações

O diferencial do Turismo Acadêmico e outros segmentos é um dos argumentos utilizados para demonstrar, evidentemente, a sua condição no mercado turístico. As conceituações e comentários inseridos neste documento foram, em grande parte, extraídos do nosso projeto de graduação citado na nota abaixo.

As variáveis divergentes e convergentes da visita técnica na teoria e na prática, com os segmentos que mais se assemelham ao desenvolvimento da viagem, são segmentos de turismo cultural, científico, educacional e de estudos.

A produção da visita técnica amparada pelo ato de viajar e conhecer localidades e atrativos propõe considerá-la como um novo segmento, e que os estudos sobre tal argumentação, apesar de merecer uma maior dinâmica de pesquisa e análise, é importante ficar registrado que tal propositura tem fundamentos suficientes para, inclusive, situá-la com o título de Turismo Acadêmico.

Vamos apresentar as diversas conceituações do turismo que se assemelham à prática da visita técnica mas que, como poderá ser observado, não inserem na sua contextualização a efetiva idéia da prática do turismo que é realizado pelas IES.

Conforme José Vicente de Andrade, no livro Turismo, fundamentos e dimensões, o autor manifesta-se em relação ao turismo cultural, da seguinte maneira:

A experiência humana e todas as suas manifestações se constituem em fator cultural, mas, por coerência e respeito às finalidades que são meios classificatórios do turismo, a expressão turismo cultural possui conotação restritiva e abrange exclusivamente as atividades que se efetuam através de deslocamentos para a satisfação de objetivos de encontro com emoções artísticas, científicas, de formação e de informação nos diversos ramos existentes, em decorrência das próprias riquezas da inteligência e da criatividade humanas. (p.71)

Ainda nessa linha de caracterização da prática do turismo cultural, José Vicente de Andrade ressalta que a motivação do turismo cultural depende mais dos turistas como elementos ativos do que da cultura dos receptivos que eles visitam, pois a simples oportunidade de constatação de realidades estranhas pode ser insuficiente para que elas se tornem, de fato, conhecidas (p.71).

Assim, o autor tende a caracterizar o turismo cultural de maneira mais voltada ao aprendizado ou à recepção de informações e dados que proporcionem ao turista, seja ele estudante ou não, e de maneira intrínseca, a qualificação intelectual que se buscou (expectativa de encontrar o que preparou para ver e ouvir) ou que se adquiriu (o que encontrou e que não estava dentro do planejamento da viagem), interiorizando-a e produzindo conhecimentos para usos diversos ou apenas para crescimento cultural de cunho pessoal.

Nesta mesma linha, aparece a classificação, citada pelo autor como subdivisão do turismo cultural, que é o turismo científico, em que a denominação dessa atividade ou segmentação tem várias variáveis que devem ser analisadas, ao se comparar com a prática da visita técnica.

Os pontos convergentes da atividade denominada visita técnica com o turismo científico instauram-se na necessidade e no interesse da realização dos estudos e pesquisas, que podemos traduzir como elementos de caráter similar ao da visita técnica:

O interesse ou a necessidade de realização de estudos e pesquisas é o elemento motivador do turismo científico, que se caracteriza pelos interesses pessoais dos turistas ou visitantes para com as fontes e os objetos das ciências. Por sua natureza, identifica-se, exclusivamente, pela finalidade e pelo comportamento sistemático do turista, no núcleo receptivo em que se encontra. (Andrade, p.72)

A dinâmica resultante da atividade denominada visita técnica pode ser evidenciada também na prática da atividade desenvolvida no turismo científico, com relação aos locais de visitação:

$O$ autêntico turismo científico pode realizar-se tanto em locais e regiões desprovidos da suficiente estrutura urbana como em regiões poupadas em sua natureza primitiva, ou em locais e regiões dotados de maior nível de desenvolvimento turístico. (Andrade, p.72)

Já em outros pontos, além da própria discordância do autor quanto ao comparativo que poderia se dar à visita técnica:

Em termos vulgares, o turismo científico é denominado viagem de estudos, excursão científica, viagem de pesquisa e outras denominações menos freqüente e mais erradas ou inexatas. (Andrade, p.72)

Há, também, que se referir ao deslocamento quanto ao exercício individual que o turismo científico permite e que, na visita técnica, não se concebe:

Efetua-se de modo individual ou em grupos reduzidos, sempre que a motivação é científica, no sentido estrito da palavra. (Andrade, p.72)

E sobre o envolvimento de cunho estritamente prazeroso do fazer turismo, percebe-se uma relação eqüidistante se comparado à visita técnica, tomando-se por base a análise como turista do lazer e da qualidade dos serviços:

Neste tipo de turismo, o lazer e o repouso tornam-se elementos secundários e, não raro, chegam a inexistir, em virtude da própria programação ou dos objetivos a que os turistas ou visitantes se propõem. (Andrade, p.73)

Outras conceituações e considerações em relação ao turismo cultural devem ser analisadas em função da própria dinâmica que é traduzida para a literatura turística e que, em comparação à visita técnica, demonstra divergências e similaridades, objetivando ainda mais, o entendimento desse tipo de atividade.

No livro Turismo, o desafio da sustentabilidade, Marta de Azevedo Irving e Júlia Azevedo, enfocando a sustentabilidade faz o seguinte apontamento quanto ao turismo cultural:

É neste cenário que o turismo cultural desponta fortalecido como uma das vertentes mais significativas da dimensão cultural do desenvolvimento: pela riqueza de variantes que comporta; pelas interfaces que motiva; pelos desdobramentos que pode estimular; pelos efeitos possíveis na construção da cidadania; pela valorização da alteridade, isto é, a compreensão da existência de outros patrimônios e ações culturais que, assim como os nossos, merecem igual respeito. Também pelo retorno econômico que propicia e, sobretudo, pelo compromisso que assume com as gerações futuras. (p.151)

Em outra análise, agora quanto ao turismo de estudos, recorremos a Gil Nuno Vaz, que propõe a seguinte distinção: Esta modalidade de turismo divide-se basicamente em: turismo educacional propriamente dito, de formação acadêmica, e o turismo técnico-científico, de aperfeiçoamento profissional.

Dentro da primeira modalidade, a grande fatia fica por conta das viagens para estudos de idiomas, procuradas principalmente por jovens. A essência desses pacotes é aliar ao conhecimento um envolvimento do aluno com a 
comunidade nativa da língua, além do relacionamento com estudantes de outras nacionalidades. Esse contexto proporciona condições favoráveis para que o estudante perca a inibição natural de se expressar em outro idioma e ganhe mais confiança e independência

...o turismo, como qualquer mercado dinâmico, não se prende a enquadramentos, pois a criatividade na elaboração de produtos sempre rompe fronteiras de classificação. O turismo de estudos é um segmento que ilustra exemplarmente essa característica do setor. Aliando o interesse por uma área de estudo e uma atividade de preferência do turista, as operadoras elaboram pacotes que misturam o útil ao agradável, juntando o curso intensivo de um idioma (inglês, francês, italiano, que são os mais procurados) com a prática ou aprendizado de mergulho, esqui, culinária, moutain bike...

O turismo técnico-científico atende aos interesses de profissionais em busca de aprimoramento. A crescente demanda por cursos de aperfeiçoamento tem provocado a elaboração de programas específicos, como o CEP _ Career Exploration Program (Programa de Desenvolvimento de Carreira) da SIS, que possibilita ainda experiência comunitária e a prática do idioma (o participante deve ter obrigatoriamente conhecimento básico da língua). (Vaz, p.167/168)

Com a relação ao turismo científico, Joadir Montaner Montejano, faz citações que muito tem a ver com o comparativo que buscamos para a visita técnica:

Ainda que possa estar relacionado com o turismo cultural ou o turismo verde, o turismo científico já se constituiu em atividade turística com personalidade própria, baseada em visitas, estadas ou viagens a lugares geográficos onde a natureza, por meio de sua orografia, fauna, flora, fenômenos e paisagens naturais, oferece possibilidades para conhecer mais de perto tudo que for relacionado às ciências naturais. Este tipo de atividade pode ser combinado com outras modalidades.

Tipo de clientela: o segmento da população turística interessada nesse tipo de atividade está concentrado basicamente na população estudantil, acadêmica, e qualquer outra amante da natureza e da ciência.

Destinos: qualquer lugar do mundo onde a natureza possa oferecer um atrativo que tenha interesse de ser visitado do ponto de vista das ciências naturais: museus, parque naturais, reservas de animais, etc. Essa atividade pode ser desenvolvida em qualquer um dos cinco continentes. (Montejano, p.270)

Turismo acadêmico: uma visita mais do que técnica

O Turismo Acadêmico chegou para ficar, com uma deferência, ele não só proporciona o turismo àqueles que dele participam, como também retira dele importantes e proveitosas lições.

Enfim, o Turismo Acadêmico "aprende, ensina, contribui e qualifica", e Isso é ótimo para o turismo do $3^{\circ}$ milênio. Independente da necessidade dos instrumentos didáticos e pedagógicos que o caracterizam e diferenciam de outros segmentos turísticos, o "novo" nicho do mercado é a fórmula mais atual de se trabalhar o turismo, com vivacidade, qualificação e profissionalismo, ou seja, para cada "ação" acadêmica sempre haverá inúmeras "reações" acadêmicas, científicas, sociais, culturais, históricas, ambientais e mercadológicas - é a beleza incomensurável transposta pela sinergia do Turismo Acadêmico.

\begin{abstract}
NOTA: Importante ressaltar que tal análise vem iniciou-se no ano de 2000, quando, em função da necessidade de qualificar as visitas técnicas realizadas por nós, na época graduando, publiquei o livro VISITA TÉCNICA, UMA INVESTIGAÇÃO ACADÊMICA, que trata exclusivamente da preparação, organização e execução das mesmas, onde propunha a interação de discentes, docentes e instituição. A partir daí, a monografia de graduação fol desenvolvida, no fim de 2002, sobre a DINÂMICA DAS VISITAS TÉCNICAS NOS CURSOS DE TURISMO E HOTELARIA DAS INSTITUICCÕES DE ENSINO SUPERIOR DE GOIÂNIA, baseada, principalmente, nas próprias indicações constantes no livro. Foi um trabalho árduo, onde além das informações e dados colhidos em 5 instituições de ensino superior de Goiânia, foram feitos questionários com professores e coordenadores de cursos de turismo e hotelaria de diversas instituições do Brasil, por ocasião do Congresso Brasileiro de Turismo-2002, realizado pela ABBTUR, no mês de maio daquele ano, em Foz do Iguaçu. Esta monografia da graduação, vale ressaltar, tem dados interessantes que, inclusive, servirão de base para o meu projeto de especialização em Pesquisa e Docência em Turismo e Hospitalidade, pela Universidade de Brasília-UnB, a ser concluído no final de 2003, onde a proposta é de inserir a visita técnica como disciplina curricular, de maneira efetiva. A defesa da visita técnica como segmento de mercado turismo com a denominação Turismo Acadêmico, pode ser entendida pela disposição constante no desenvolvimento do projeto de monografia da graduação. (Se houver interesse entrar em contato: visitatecnica.vt@bol.com.br)
\end{abstract}

REFERÊNCIAS BIBLIOGRAFICAS

ANDRADE, José Vicente. Turismo, fundamentos e dimensões. São Paulo, Ática, 1995.

COOPER, Chris, SHEPHERD, Rebecca, WESTLAKE, John. Educando os educadores em Turismo: Manual de Educação em Turismo e Hospitalidade. São Paulo: Roca, 2001.

FRANZ, Victor Rudio. Introdução ao projeto de pesquisa científica. 30a ed., Petrópolis: Vozes, 2002.

IRVING, Marta de Azevedo e Júlia Azevedo. Turismo, o desafio da sustentabilidade. São Paulo: Futura, 2002.

MONTEJANO, Joadir Montaner. Estrutura do mercado turístico. 2a ed. São Paulo: Roca, 2001.

PRADO, Wânia Gaspar Martins do. Manual prático para organização de viagens. São Paulo: Aleph, 2002.

REJOWSKI, Mirian. Turismo e pesquisa científica. 5a ed. São Paulo: Papirus, 2001.

VAZ, Gil Nuno. Marketing Turístico: Receptivo e emissivo. São Paulo: Pioneira, 1999.

VELOSO, Marcelo Parreira. Visita Técnica, uma investigação acadêmica. Goiânia: Kelps, 


\section{Apêndice B - Ofício e Questionário às IES}

\section{Ofício às IES}

Goiânia, 14 de julho de 2003

Prezados Senhores,

Sou Bacharel em Turismo e especializando em Pesquisa e Docência em Turismo e Hospitalidade pelo Centro de Excelência em Turismo da Universidade de Brasília-UnB, e tenho como projeto (monografia) a pesquisa sobre a Utilização da Visita Técnica nos Cursos de Turismo e Hotelaria, tomando-se por base a estruturação e organização da mesma em função da sua inserção nos projetos pedagógicos e, por conseguinte, nas grades curriculares e extracurriculares das Instituições de Ensino Superior no Brasil. Sou, também, autor do livro Visita Técnica - uma investigação acadêmica, publicado no ano de 2000, e tive como projeto de graduação, no ano de 2002, a pesquisa aplicada sobre visita técnica nas IES de Goiânia.

Neste sentido, dando continuidade a minha "peregrinação" em entender melhor sobre como a visita técnica é planejada e projetada, seja como disciplina curricular, extracurricular, atividade complementar ou de extensão, é que venho solicitar que se dignem a atender minha solicitação sobre as informações e dados elencados no questionário anexo, com a maior brevidade possível, vez que todo o trabalho de recepção, compilação e tabulação dos dados merece criterioso estudo e atenção para cada item disposto, além do curto espaço que tenho para a concretização do meu projeto (monografia), que expira no final de agosto, quando devo estar com todas as informações e dados para apresentar, num primeiro momento, para análise e orientação.

Espero poder contar a preciosa atenção de todos e, dentro das minhas possibilidades, buscarei apresentar-Ihes os resultados que obtiver, após, evidentemente, a conclusão da especialização.

Grato,

Marcelo Parreira Veloso

Bacharel em Turismo

Às

Instituições de Ensino Superior do Brasil

At. Diretorias e Coordenações de Cursos de Turismo e Hotelaria 


\section{QUESTIONÁRIO ÀS IES}

AS INFORMAÇÕES (DE MANEIRA SUCINTA) QUE NECESSITO SÃO:

1. Dados e informações do projeto pedagógico e da grade curricular do curso de turismo e hotelaria sobre Visita Técnica (Pesquisa ou Observação Sistemática?);

2. Qual é a relação da visita técnica com a interdisciplinaridade? Se existem instrumentos didáticos e metodológicos que permitem estabelecer essa relação?

3. Dados sobre a organização da $\mathbf{1}^{\mathrm{a}}$ e última Visita Técnica por cada turma - É possível verificar se houve mudanças nos conceitos dos alunos - tomando-se por base que a maioria das vezes na $1^{\text {a }}$ visita técnica os alunos ainda não têm uma visão abrangente (teórica e técnica) sobre a importância da realização da mesma, ao contrário da última, onde entende-se que há uma relação mais acadêmica e profissional sobre a utilidade e necessidade de tal atividade - isso pode ser confirmado?;

4. Quais são as referências bibliográficas utilizadas para a organização e execução da visita técnica?

5. Como é considerada a visita técnica:

a) Para a Instituição?

b) Para a Coordenação do Curso?

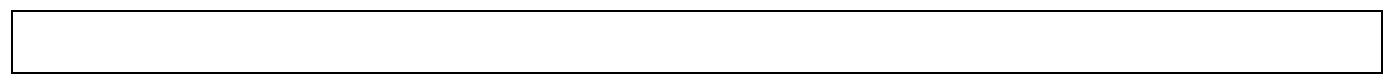

c) Para os professores que auxiliam na organização e execução?

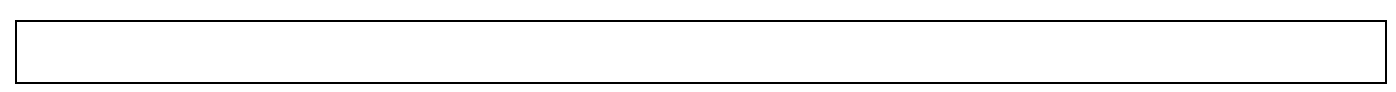

d) Para os alunos que executam?

6. Dados sobre a estruturação da visita técnica em banco de dados, informações, registro, seminários; 
7. Informar em números ou percentuais:

a) Visitas técnicas realizadas por ano;

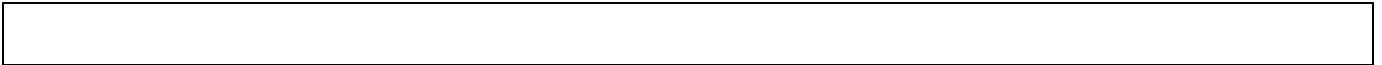

b) Quantidades de docentes e discentes que participam

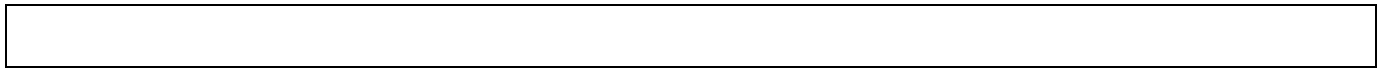

c) Citar as 03 primeiras localidades onde se realizam mais visitas;

d) O tempo médio (quantidade de dias) gasto para realização das visitas;

e) Tipo de veículos que utilizam;

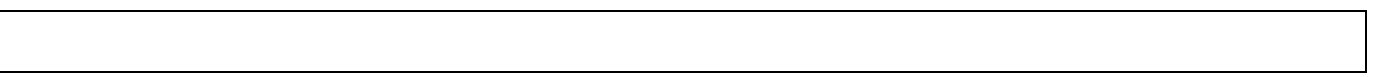

f) Tipo de hospedagem;

g) Outros dados que puderem disponibilizar que consideram de real importância para a realização da visita técnica.

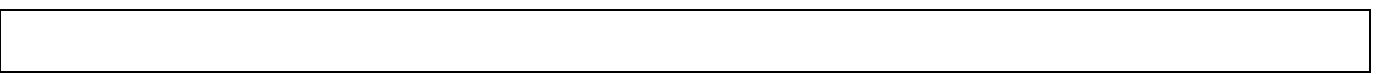

Espero poder contar a preciosa atenção de todos e, dentro das minhas possibilidades, buscarei apresentar-Ihes os resultados que obtiver, após, evidentemente, a conclusão da especialização.

Grato,

Marcelo Parreira Veloso

Bacharel em Turismo

FAVOR INDICAR:

Nome da Instituição

Nome do(a) Coordenador(a) ou Diretor(a) do Curso de Turismo

Dados para contato: Endereço, telefone, e-mail, fax 


\section{Apêndice C - Disciplinas constantes das grades curriculares dos cursos de Turismo e Hotelaria pesquisados}

\begin{tabular}{|c|c|c|c|}
\hline \multicolumn{4}{|c|}{$1^{\circ}$ ANO } \\
\hline & Disciplina referência & Variáveis & Qtde \\
\hline 1 & A civilização brasileira e sua relação com o turismo & A civilização brasileira e sua relação com o turismo & 1 \\
\hline 2 & A civilização ocidental e sua relação com o turismo & A civilização ocidental e sua relação com o turismo & 1 \\
\hline 3 & Administração & Administração aplicada ao turismo & 2 \\
\hline & & Administração de empresas & 2 \\
\hline & & Administração de empresas turísticas i & 1 \\
\hline & & Administração hoteleira & 3 \\
\hline & & Introdução à administração & 5 \\
\hline & & Teoria da administração & 1 \\
\hline 4 & Agenciamento & Agenciamento turístico & 1 \\
\hline \multirow[t]{2}{*}{5} & Animação, lazer e recreação turística & Lazer e animação turística & 1 \\
\hline & & Técnicas de recreação e animação & 1 \\
\hline \multirow[t]{3}{*}{6} & Antropologia & Antropologia cultural & 2 \\
\hline & & Antropologia e cultura brasileira & 1 \\
\hline & & Antropologia e turismo & 1 \\
\hline \multirow[t]{3}{*}{7} & Atividades complementares & Atividades complementares & 2 \\
\hline & & Pesquisa temática & 1 \\
\hline & & Visita técnica e relatórios & 1 \\
\hline 8 & Atividades de práticas orientadas & Atividades de práticas orientadas & 1 \\
\hline 9 & Atividades supervisionadas & Atividades supervisionadas & 1 \\
\hline 10 & Cálculos & Cálculo financeiro & 1 \\
\hline \multirow[t]{2}{*}{11} & Cartografia & Cartografia & 1 \\
\hline & & Elementos de cartografia & 1 \\
\hline \multirow[t]{3}{*}{12} & Computação e informática & Informática & 1 \\
\hline & & Informática aplicada ao turismo & 1 \\
\hline & & Introdução ao uso do micro computador & 1 \\
\hline \multirow[t]{5}{*}{13} & Comunicação & Comunicação e expressão & 2 \\
\hline & & Comunicação e expressão oral e escrita & 1 \\
\hline & & Comunicação e turismo & 1 \\
\hline & & Comunicação oral e escrita & 1 \\
\hline & & Comunicação verbal e não verbal & 1 \\
\hline 14 & Construção histórica e cultural do Brasil & Construção histórica e cultural do Brasil & 1 \\
\hline \multirow[t]{2}{*}{15} & Contabilidade & Contabilidade & 1 \\
\hline & & Contabilidade gerencial & 1 \\
\hline \multirow[t]{4}{*}{16} & Direito e legislação & Fundamentos do direito & 2 \\
\hline & & Introdução ao estudo do direito & 1 \\
\hline & & Legislação turística & 2 \\
\hline & & Noções do direito & 1 \\
\hline \multirow[t]{5}{*}{17} & Economia & Economia & 3 \\
\hline & & Economia do turismo & 2 \\
\hline & & Economia e o setor de serviços & 1 \\
\hline & & Economia geral & 1 \\
\hline & & Economia política & 1 \\
\hline 18 & Ecoturismo & Ecoturismo & 1 \\
\hline 19 & Educação física (prática desportiva) & Educação física (prática desportiva) & 1 \\
\hline 20 & Estágio & Estágio voluntário & 2 \\
\hline \multirow[t]{3}{*}{21} & Estatística & Estatística & 1 \\
\hline & & Estatística aplicada ao turismo & 3 \\
\hline & & Introdução à estatística & 1 \\
\hline 22 & Estudos & Estudos brasileiros & 1 \\
\hline 23 & Ética & Ética geral & 1 \\
\hline
\end{tabular}




\begin{tabular}{|c|c|c|c|}
\hline 24 & Eventos & Eventos & 1 \\
\hline \multirow[t]{3}{*}{25} & Filosofia & Filosofia & 1 \\
\hline & & Filosofia e ética & 1 \\
\hline & & Introdução a filosofia & 1 \\
\hline 26 & Fotografia & Fotografia e imagem do turismo & 1 \\
\hline \multirow[t]{9}{*}{27} & Geografia & Geografia aplicada ao turismo & 4 \\
\hline & & Geografia das paisagens turísticas & 1 \\
\hline & & Geografia do Brasil & 2 \\
\hline & & Geografia geral & 4 \\
\hline & & Geografia geral aplicada ao turismo & 1 \\
\hline & & Geografia turística do Brasil/cartografia & 1 \\
\hline & & Elementos geográficos do turismo & 2 \\
\hline & & O espaço geográfico brasileiro & 1 \\
\hline & & O espaço geográfico mundial & 1 \\
\hline \multirow[t]{10}{*}{28} & História & História & 2 \\
\hline & & História contemporânea & 1 \\
\hline & & História da arte & 2 \\
\hline & & História da arte e do turismo & 1 \\
\hline & & História da cultura & 4 \\
\hline & & História da cultura e da arte & 2 \\
\hline & & Historia da cultura universal & 1 \\
\hline & & História do Brasil & 2 \\
\hline & & Historia do Brasil aplicada ao turismo & 1 \\
\hline & & História do Brasil colônia & 1 \\
\hline 29 & Hospedagem & Hospedagem & 1 \\
\hline 30 & Hotelaria & Introdução à hotelaria & 1 \\
\hline 31 & Laboratório & Laboratório de textos & 1 \\
\hline 32 & Leitura & Leitura e produção de textos & 1 \\
\hline \multirow[t]{7}{*}{33} & Língua estrangeira & Espanhol & 1 \\
\hline & & Inglês & 4 \\
\hline & & Inglês instrumental & 2 \\
\hline & & Laboratório de inglês & 1 \\
\hline & & Língua estrangeira & 1 \\
\hline & & Língua estrangeira i (inglês ou francês) & 2 \\
\hline & & Língua inglesa aplicada ao turismo & 1 \\
\hline \multirow[t]{3}{*}{34} & Língua portuguesa & Língua portuguesa & 5 \\
\hline & & Língua portuguesa instrumental & 1 \\
\hline & & Português: redação e expressão oral & 1 \\
\hline \multirow[t]{2}{*}{35} & Matemática & Elementos de matemática e estatística & 1 \\
\hline & & Matemática & 1 \\
\hline \multirow[t]{5}{*}{36} & Meio ambiente e ecologia & Ecologia & 1 \\
\hline & & Fauna e flora & 1 \\
\hline & & Fundamentos de ecologia & 1 \\
\hline & & Meio ambiente & 1 \\
\hline & & Meio ambiente e ecologia & 1 \\
\hline 37 & Mercado turístico & Sistema Integrado de turismo - Sistur & 1 \\
\hline \multirow[t]{6}{*}{38} & Metodologia & Metodologia científica & 6 \\
\hline & & Metodologia de pesquisa & 1 \\
\hline & & Metodologia de pesquisa científica & 1 \\
\hline & & Metodologia do estudo & 1 \\
\hline & & Metodologia em turismo & 1 \\
\hline & & Métodos e téc. de est. e pesq. Bibliográfica & 1 \\
\hline 39 & Museologia & Museologia & 1 \\
\hline
\end{tabular}




\begin{tabular}{|c|c|c|c|}
\hline \multirow[t]{4}{*}{40} & Organização e estruturação & Estrutura e organização do turismo & 1 \\
\hline & & Organização e administração & 1 \\
\hline & & Teoria das organizações & 1 \\
\hline & & Teoria geral das organizações & 1 \\
\hline 41 & Política e turismo & Política e turismo & 1 \\
\hline 42 & Processos do conhecer & Processos do conhecer & 1 \\
\hline \multirow[t]{2}{*}{43} & Produção de textos técnicos para turismo & Produção de textos técnicos para turismo & 1 \\
\hline & & Recepção e produção de textos não literários & 1 \\
\hline \multirow[t]{2}{*}{44} & Psicologia & Psicologia & 1 \\
\hline & & Psicologia aplicada ao turismo & 1 \\
\hline 45 & Redação e expressão oral & Redação e expressão oral & 1 \\
\hline 46 & Relações interpessoais no turismo & Relações interpessoais no turismo & 1 \\
\hline \multirow[t]{2}{*}{47} & Seminários & Seminário multidisciplinar & 1 \\
\hline & & Seminário: discussão e temática & 1 \\
\hline \multirow[t]{8}{*}{48} & Sociologia & Sociologia & 5 \\
\hline & & Sociologia aplicada & 1 \\
\hline & & Sociologia aplicada ao turismo & 2 \\
\hline & & Sociologia do lazer & 4 \\
\hline & & Sociologia do lazer e do turismo & 1 \\
\hline & & Sociologia do turismo & 2 \\
\hline & & Sociologia e antropologia cultural & 1 \\
\hline & & Sociologia geral & 1 \\
\hline 49 & Técnicas de pesquisa & Técnicas de pesquisa em turismo & 1 \\
\hline \multirow[t]{2}{*}{50} & Tecnologia da informação & Tecnologia da informação & 1 \\
\hline & & Tecnologia da informação turística & 1 \\
\hline \multirow[t]{5}{*}{51} & Teoria do turismo & Fundamentos do turismo & 1 \\
\hline & & Introdução ao turismo & 1 \\
\hline & & Teoria e técnica do turismo & 3 \\
\hline & & Teoria geral do turismo & 11 \\
\hline & & Teorias do turismo & 1 \\
\hline 52 & Tópicos de história urbana & Tópicos de história urbana & 1 \\
\hline 53 & Tptur - agência/transporte & Tptur - agência/transporte & 1 \\
\hline \multirow[t]{2}{*}{54} & Transporte & Sistemas de transportes e turismo & 1 \\
\hline & & Transportes & 1 \\
\hline 55 & Trabalho de análise interdisciplinar & Trabalho de análise interdisciplinar & 1 \\
\hline 56 & Turismo e novas tecnol. com informações & Turismo e novas tecnol. com informações & 1 \\
\hline 57 & Visita técnica & Visita técnica & 1 \\
\hline
\end{tabular}

\begin{tabular}{|l|l|l|c|}
\hline \multicolumn{2}{|c|}{ Disciplina referência } & \multicolumn{1}{c|}{ Variáveis } & Qtde \\
\hline & \multicolumn{2}{|c|}{ ANO } & 3 \\
\hline 1 & Administração & Adm. Hoteleira & 1 \\
\hline & & Administração aplicada ao turismo & 1 \\
\hline & & Administração de empresas de turismo & 1 \\
\hline & & Administração de empresas turísticas & 2 \\
\hline & & Administração de recursos materiais e patrimoniais & 1 \\
\hline & & Administração de sistemas de informática & 1 \\
\hline & & Administração dos meios de hospedagem & 1 \\
\hline & & Administração em turismo & 1 \\
\hline & & Administração financeira & 1 \\
\hline & & Administração financeira e orçamentária i & 2 \\
\hline & & Fundamentos da administração & 1 \\
\hline 2 & Agenciamento & Agência de viagens & 5 \\
\hline & & Agenciamento & 1 \\
\hline & & Agências de viagens e transportes & \\
\hline
\end{tabular}




\begin{tabular}{|c|c|c|c|}
\hline & & Agências de viagens e turismo & 1 \\
\hline & & Agências e transportes & 1 \\
\hline 3 & Análise estrutural do turismo & Análise estrutural do turismo & 2 \\
\hline 4 & Animação turística, recreação e lazer & Animação turística e eventos & 1 \\
\hline & & Lazer e animação & 1 \\
\hline & & Lazer e turismo & 1 \\
\hline & & Recreação e lazer & 1 \\
\hline & & Turismo e lazer & 1 \\
\hline 5 & Antropologia & Antropologia & 1 \\
\hline 6 & Arte e cultura popular & Arte e cultura popular & 1 \\
\hline \multirow[t]{3}{*}{7} & Atividades complementares & Atividades complementares & 2 \\
\hline & & Visita técnica & 1 \\
\hline & & Visita técnica, trabalho interdisciplinar & 1 \\
\hline 8 & Cartografia & Cartografia & 1 \\
\hline 9 & Ciências ambientais & Ciências ambientais & 1 \\
\hline 10 & Comportamento organizacional & Comportamento organizacional & 1 \\
\hline \multirow[t]{2}{*}{11} & Contabilidade & Contabilidade aplicada à empresas turísticas & 1 \\
\hline & & Contabilidade gerencial no turismo & 1 \\
\hline \multirow[t]{4}{*}{12} & Cultura & Cultura Brasileira & 1 \\
\hline & & Cultura e arte barroca & 1 \\
\hline & & Cultura popular & 1 \\
\hline & & Cultura religiosa & 1 \\
\hline \multirow[t]{5}{*}{13} & Direito e legislação & Direito e legislação aplicada ao turismo & 1 \\
\hline & & Direito e legislação turística & 1 \\
\hline & & Instituições de direito público e privado & 1 \\
\hline & & Legislação aplicada ao turismo & 1 \\
\hline & & Noções de Direito & 1 \\
\hline 14 & Disciplinas eletivas & Disciplinas eletivas & 3 \\
\hline \multirow[t]{5}{*}{15} & Economia & Análise econômica do turismo & 2 \\
\hline & & Análise microeconômica do turismo & 2 \\
\hline & & Economia & 2 \\
\hline & & Economia aplicada ao turismo & 2 \\
\hline & & Economia do turismo & 1 \\
\hline 16 & Ecoturismo & Ecoturismo & 2 \\
\hline 17 & Estágio & Estágio integrador & 2 \\
\hline \multirow[t]{4}{*}{18} & Estatística & Estatística & 1 \\
\hline & & Estatística aplicada à administração & 1 \\
\hline & & Estatística aplicada ao turismo & 3 \\
\hline & & Noções de estatísticas & 1 \\
\hline 19 & Estudos Brasileiros & Estudos Brasileiros & 1 \\
\hline \multirow[t]{2}{*}{20} & Ética & Ética profissional & 1 \\
\hline & & Ética profissional e legislação do turismo & 1 \\
\hline \multirow[t]{3}{*}{21} & Eventos & Eventos & 1 \\
\hline & & Organização de eventos e cerimonial & 1 \\
\hline & & Organização de eventos & 1 \\
\hline 22 & Filosofia & Filosofia & 2 \\
\hline 23 & Folclore & Folclore & 1 \\
\hline 24 & Fundamentos históricos do turismo & Fundamentos históricos do turismo & 1 \\
\hline \multirow[t]{2}{*}{25} & Gastronomia & Gastronomia & 1 \\
\hline & & Gastronomia e turismo & 1 \\
\hline \multirow[t]{5}{*}{26} & Geografia & Geografia aplicada ao turismo & 1 \\
\hline & & Geografia de Minas Gerais & 1 \\
\hline & & Geografia do amazonas & 1 \\
\hline & & Geografia do Brasil & 1 \\
\hline & & Geografia do Brasil aplicada ao turismo & 1 \\
\hline
\end{tabular}




\begin{tabular}{|c|c|c|c|}
\hline & & Geografia do turismo & 1 \\
\hline & & Geografia e cartografia & 1 \\
\hline & & Geografia regional do Brasil & 1 \\
\hline \multirow[t]{7}{*}{27} & Gestão & Gestão de agências de viagem e turismo & 1 \\
\hline & & Gestão de agências de viagens & 1 \\
\hline & & Gestão de alimentos e bebidas & 1 \\
\hline & & Gestão de empreendimentos turísticos & 1 \\
\hline & & Gestão de meios de hospedagens & 1 \\
\hline & & Gestão de pessoas & 1 \\
\hline & & Gestão de recursos humanos & 1 \\
\hline & História & História da arte & 3 \\
\hline & & História da cultura & 2 \\
\hline & & História da cultura, arte/pat. Cult. & 1 \\
\hline & & História das civilizações & 1 \\
\hline & & História do estado (UF) & 2 \\
\hline & & História do Brasil & 3 \\
\hline & & História do Brasil e do estado (UF) & 1 \\
\hline & & História do Brasil independente & 1 \\
\hline 29 & Hospedagem & Hospedagem & 1 \\
\hline 30 & Hotelaria & Hotelaria & 2 \\
\hline \multirow[t]{2}{*}{31} & Informática & Informática & 4 \\
\hline & & Processamento de dados & 1 \\
\hline 32 & Interpretação do patrimônio histórico e cultural & Interpretação do patrimônio histórico e cultural & 1 \\
\hline \multirow[t]{2}{*}{33} & Laboratório & Laboratório de aprendizagem & 1 \\
\hline & & Lab. De aprendizagem / estágios extra curriculares & 1 \\
\hline \multirow[t]{9}{*}{34} & Língua estrangeira & Laboratório de espanhol & 1 \\
\hline & & Língua espanhola aplicada ao turismo & 1 \\
\hline & & Língua espanhola & 3 \\
\hline & & Língua espanhola instrumental & 1 \\
\hline & & Língua estrangeira & 2 \\
\hline & & Língua estrangeira (inglês ou francês) & 1 \\
\hline & & Língua francesa instrumental & 1 \\
\hline & & Língua inglesa & 4 \\
\hline & & Língua inglesa instrumental & 1 \\
\hline \multirow[t]{3}{*}{35} & Marketing & Marketing & 3 \\
\hline & & Marketing de serviços turísticos & 1 \\
\hline & & Marketing turístico & 1 \\
\hline \multirow[t]{2}{*}{36} & Matemática & Matemática comercial e financeira & 1 \\
\hline & & Matemática financeira & 2 \\
\hline 37 & Meio ambiente & Turismo e meio ambiente & 4 \\
\hline 38 & Meios de hospedagem & Meios de hospedagem & 1 \\
\hline \multirow[t]{2}{*}{39} & Mercado & Mercado turístico - Sistur & 1 \\
\hline & & Mercadologia & 1 \\
\hline \multirow[t]{5}{*}{40} & Metodologia & Introdução à metodologia da pesquisa & 1 \\
\hline & & Metodologia da pesquisa & 3 \\
\hline & & Metodologia da pesquisa em turismo & 1 \\
\hline & & Métodos e técnicas de pesquisa & 2 \\
\hline & & Métodos e técnicas de pesquisa em turismo & 1 \\
\hline 41 & Museologia & Museologia & 3 \\
\hline \multirow[t]{2}{*}{42} & Organização & Organização do espaço mundial & 1 \\
\hline & & Organizações e métodos & 1 \\
\hline \multirow[t]{2}{*}{43} & Pesquisa & Pesquisa da oferta turística & 1 \\
\hline & & Pesquisa de mercado turístico & 1 \\
\hline
\end{tabular}




\begin{tabular}{|c|c|c|c|}
\hline & & Pesquisa de opinião pública e mercadologia & 1 \\
\hline & & Pesquisa em turismo & 1 \\
\hline \multirow[t]{3}{*}{44} & Planejamento & Planejamento dos espaços turísticos & 1 \\
\hline & & Planejamento e organização do turismo & 2 \\
\hline & & Planejamento regional e urbano & 1 \\
\hline \multirow{2}{*}{\multicolumn{2}{|c|}{45 Potur }} & Potur - eventos & 1 \\
\hline & & Potur - formação de produto & 1 \\
\hline 46 & Promoção e comercialização & Promoção e comercialização de produtos turísticos & 2 \\
\hline \multirow[t]{2}{*}{47} & Propaganda e publicidade & Técnica publicitária i & 1 \\
\hline & & Propaganda e publicidade & 1 \\
\hline \multirow[t]{4}{*}{48} & Psicologia & Fundamentos de psicologia & 1 \\
\hline & & Introdução à psicologia & 1 \\
\hline & & Psicologia & 4 \\
\hline & & Psicologia aplicada ao turismo & 4 \\
\hline 49 & Relações públicas & Relações públicas aplicadas ao turismo & 1 \\
\hline \multirow[t]{4}{*}{50} & Sociologia & Sociologia aplicada à administração & 1 \\
\hline & & Sociologia do lazer & 1 \\
\hline & & Sociologia do turismo & 1 \\
\hline & & Sociologia do turismo e lazer & 1 \\
\hline \multirow[t]{6}{*}{51} & Teoria & Teoria da cultura & 2 \\
\hline & & Teoria da recreação & 1 \\
\hline & & Teoria das organizações & 1 \\
\hline & & Teoria do lazer & 1 \\
\hline & & Teoria do planejamento i & 1 \\
\hline & & Teoria e técnica do turismo i & 1 \\
\hline 52 & Tipologia do turismo & Tipologia do turismo & 1 \\
\hline 53 & Tópicos especiais & Tópicos especiais & 2 \\
\hline 54 & Trabalho análise interdisciplinar & Trabalho análise interdisciplinar & 1 \\
\hline 55 & Tradição e folclore & Tradição e folclore & 1 \\
\hline 56 & Transportes & Transportes & 3 \\
\hline 57 & Turismo integrado & Turismo integrado & 1 \\
\hline
\end{tabular}

\begin{tabular}{|l|l|l|c|}
\hline \multicolumn{2}{|c|}{ Disciplina referência } & \multicolumn{1}{c|}{ Variáveis } & Qtde \\
\hline 1 & Administração & Adm. De recursos humanos & 3 \\
\hline & & Administração da produção & 1 \\
\hline & & Administração de marketing i & 1 \\
\hline & & Administ. De recursos materiais e patrimoniais & 1 \\
\hline & & Administração financeira e orçamentária & 1 \\
\hline & & Administração serviços hoteleiros & 1 \\
\hline 2 & Agenciamento & Agencia de viagens e transportadoras & 1 \\
\hline & & Agenciamento & 2 \\
\hline & & Agenciamento turístico & 1 \\
\hline & & Agências de viagem e transporte & 1 \\
\hline & & Agências e transportes & 1 \\
\hline 3 & Alimentos \& bebidas & Alimentos \& bebidas & 2 \\
\hline & & Alimentos e bebidas - (restaurantes) & 1 \\
\hline 4 & Animação turística, recreação e lazer & Animação sócio-cultural & 1 \\
\hline & & Animação turística & 1 \\
\hline & & Lazer e animação turística & 1 \\
\hline 5 & Antropologia e práticas alimentares & Antropologia e práticas alimentares & 1 \\
\hline 6 & Arquitetura e urbanismo aplicados ao turismo & Arquitetura e urbanismo aplicados ao turismo & 1 \\
\hline 7 & Atividades complementares & Atividades complementares & 2 \\
\hline & & Projeto de implantação de restaurante & 1 \\
\hline & & Projeto de implantação de um hotel ou agência & 1 \\
\hline
\end{tabular}




\begin{tabular}{|c|c|c|c|}
\hline 8 & Comunicação social & Comunicação social & 1 \\
\hline \multirow[t]{5}{*}{9} & Contabilidade & Contabilidade e custos & 1 \\
\hline & & Contabilidade e finanças em turismo & 1 \\
\hline & & Contabilidade geral & 2 \\
\hline & & Fundamentos de contabilidade & 1 \\
\hline & & Introdução a contabilidade & 1 \\
\hline 10 & Controles gerenciais e análise financeira & Controles gerenciais e análise financeira & 1 \\
\hline 11 & Cultura e folclore & Cultura e folclore do estado & 1 \\
\hline & & Cultura popular do estado & 1 \\
\hline 12 & Deontologia profissional & Deontologia profissional & 1 \\
\hline \multirow[t]{8}{*}{13} & Direito e legislação & Direito e legislação ambiental & 1 \\
\hline & & Instituições de direito publico e privado & 1 \\
\hline & & Legislação comercial e tributária & 1 \\
\hline & & Legislação e ética profissional & 2 \\
\hline & & Legislação social & 1 \\
\hline & & Legislação turística & 2 \\
\hline & & Noções de direito & 1 \\
\hline & & Noções de direito aplicado ao turismo & 1 \\
\hline 14 & Disciplinas eletivas & Disciplinas eletivas & 2 \\
\hline 15 & Ecologia & Ecologia & 2 \\
\hline \multirow[t]{3}{*}{1} & Economia & Análise econômica e turismo & 1 \\
\hline & & Economia & 2 \\
\hline & & Economia Brasileira & 1 \\
\hline 17 & Ecoturismo & Ecoturismo & 3 \\
\hline 18 & Empreendedorismo & Empreendedorismo & 1 \\
\hline \multirow[t]{5}{*}{19} & Estágio & Estágio & 2 \\
\hline & & Estágio curricular (supervisionado) & 2 \\
\hline & & Estágio de pesquisa & 2 \\
\hline & & Estágio supervisionado & 5 \\
\hline & & Orientação do estágio supervisionado & 1 \\
\hline \multirow[t]{2}{*}{20} & Estatística & Estatística & 2 \\
\hline & & Estatística aplicada ao turismo & 2 \\
\hline \multirow[t]{2}{*}{21} & Estudos independentes & Estudos independentes & 1 \\
\hline & & Estudos turísticos brasileiros & 1 \\
\hline \multirow[t]{2}{*}{22} & Ética & Ética & 1 \\
\hline & & Ética (profissional) & 1 \\
\hline \multirow[t]{2}{*}{23} & Eventos & Eventos & 3 \\
\hline & & Organização de eventos & 4 \\
\hline 24 & Filosofia e ética profissional & Filosofia e ética profissional & 1 \\
\hline 25 & Folclore & Folclore & 2 \\
\hline 26 & Gastronomia & Gastronomia & 1 \\
\hline \multirow[t]{3}{*}{27} & Geografia & Geografia & 1 \\
\hline & & Geografia do Brasil & 1 \\
\hline & & Geografia do turismo & 1 \\
\hline \multirow[t]{10}{*}{28} & Gerenciamento e gestão & Gerenciamento em empreendimentos turísticos & 1 \\
\hline & & Gestão das organizações turísticas & 1 \\
\hline & & Gestão de empresas de turismo & 1 \\
\hline & & Gestão de meios de hospedagem & 1 \\
\hline & & Gestão de meios de transportes & 1 \\
\hline & & Gestão de organização de serviços & 1 \\
\hline & & Gestão de pessoas & 1 \\
\hline & & Gestão de unidade de conservação & 1 \\
\hline & & Gestão empreendedora & 1 \\
\hline & & Gestão estratégica do turismo & 1 \\
\hline
\end{tabular}




\begin{tabular}{|c|c|c|c|}
\hline & & Gestão financeira e estudos de viabilidade & 1 \\
\hline & & Gestão orçamentária no turismo & 1 \\
\hline \multirow[t]{3}{*}{29} & Informática & Informática & 1 \\
\hline & & Informática aplic. a empreendimentos turísticos & 1 \\
\hline & & Informática aplicada ao turismo & 2 \\
\hline \multirow[t]{2}{*}{30} & |tinerários, circuitos e roteiros turísticos & Itinerários e circuitos turísticos & 1 \\
\hline & & Org. E planejamento de roteiros ecoturísticos & 1 \\
\hline 31 & Laboratório & Laboratório de aprendizagem & 1 \\
\hline \multirow[t]{2}{*}{32} & Língua estrangeira & Espanhol & 3 \\
\hline & & Língua francesa instrumental & 1 \\
\hline 33 & Linguagens tecnológicas no turismo & Linguagens tecnológicas no turismo & 1 \\
\hline \multirow[t]{2}{*}{34} & Marketing & Marketing & 2 \\
\hline & & Marketing turístico & 5 \\
\hline 35 & Matemática & Matemática financeira & 1 \\
\hline \multirow[t]{3}{*}{36} & Meios de hospedagem & Meios de hospedagem & 2 \\
\hline & & Meios de hospedagem e hotelaria & 1 \\
\hline & & Meios de hospedagem e o turismo & 1 \\
\hline 37 & Mercadologia aplicada ao turismo & Mercadologia aplicada ao turismo & 1 \\
\hline 38 & Orçamento público & Orçamento público & 1 \\
\hline 39 & Ordenamento turístico - territorial & Ordenamento turístico - territorial & 1 \\
\hline \multirow[t]{2}{*}{40} & Organização & Organização do turismo & 1 \\
\hline & & Organização, sistemas e métodos & 1 \\
\hline \multirow[t]{3}{*}{41} & Patrimônio & Patrimônio histórico & 1 \\
\hline & & Patrimônio turístico brasileiro & 1 \\
\hline & & Patrimônio turístico do estado & 1 \\
\hline \multirow[t]{2}{*}{42} & Pesquisa & Métodos e técnicas de pesquisa em turismo & 1 \\
\hline & & Pesquisa da demanda turística & 1 \\
\hline \multirow[t]{7}{*}{43} & Planejamento & Planejamento e organização do turismo & 9 \\
\hline & & Planejamento do turismo & 1 \\
\hline & & Planejamento e organização de eventos & 2 \\
\hline & & Planej. E organização dos meios de hospedagem & 1 \\
\hline & & Planejamento estratégico & 1 \\
\hline & & Planejamento territorial e urbano do turismo & 1 \\
\hline & & Plano de desenvolvimento turístico & 1 \\
\hline \multirow[t]{2}{*}{44} & Potur & Potur - animação e lazer & 1 \\
\hline & & Potur - pesca desp. Amadora & 1 \\
\hline \multirow[t]{2}{*}{45} & Projetos & Elaboração e análise de projetos turísticos & 1 \\
\hline & & Projetos e estudo de viabilidade econômica & 2 \\
\hline 46 & Propaganda turística fotografia & Propaganda turística fotografia & 1 \\
\hline 47 & Psicodinâmica organizacional & Psicodinâmica organizacional & 1 \\
\hline 48 & Qualidade total & Qualidade total & 1 \\
\hline 49 & Redação & Redação & 1 \\
\hline 50 & Relações turísticas internacionais & Relações turísticas internacionais & 1 \\
\hline 51 & Serviços de alimentação e o turismo & Serviços de alimentação e o turismo & 1 \\
\hline \multirow[t]{4}{*}{52} & Técnicas & Técnica de comunicação publicitária & 1 \\
\hline & & Técnicas de elab. E avaliação de proj. Turísticos & 1 \\
\hline & & Técnicas de imagem & 1 \\
\hline & & Técnicas e práticas desportivas & 1 \\
\hline \multirow[t]{3}{*}{53} & Teorias & Teo. Plan. Prat. Turismo rural & 1 \\
\hline & & Teo. Prat. Comunic. Espr. Oral & 1 \\
\hline & & Teoria e prática de hospedagem & 1 \\
\hline \multirow[t]{2}{*}{54} & Tópicos especiais & Tópicos especiais & 3 \\
\hline & & Tópicos especiais em turismo & 1 \\
\hline \multirow[t]{2}{*}{55} & Transportes & Sistema de transporte & 2 \\
\hline & & Transportes turísticos & 1 \\
\hline
\end{tabular}




\begin{tabular}{|l|l|l|c|}
\hline 56 & Turismo & Turismo contemporâneo & 1 \\
\hline & & Turismo e meio ambiente & 2 \\
\hline & & Turismo e patrimônio cultural & 2 \\
\hline & & Turismo integrado & 1 \\
\hline & Turismo no espaço rural & 1 \\
\hline & & Turismo no espaço urbano & 1 \\
\hline & & Turismo, bens culturais e elementos de museologia & 1 \\
\hline
\end{tabular}

\begin{tabular}{|c|c|c|c|}
\hline \multicolumn{4}{|c|}{$4^{\circ} \mathrm{ANO}$} \\
\hline & Disciplina referência & Variáveis & Qtde \\
\hline & Administração & Administração de orçamento e finanças & 1 \\
\hline & & Administração contábil financeira & 2 \\
\hline & & Administração de patrimônio físico & 1 \\
\hline & & Administração de patrimônio planejamento físico & 1 \\
\hline & & Administração de recursos humanos & 3 \\
\hline & & Administração de recursos humanos em turismo & 1 \\
\hline & & Administração financeira e orçamento & 1 \\
\hline & & Administração serviços hoteleiros & 1 \\
\hline \multirow[t]{2}{*}{2} & Agenciamento & Agencia de viagens e transportadoras & 1 \\
\hline & & Agências de viagens & 1 \\
\hline 3 & Alimentos e bebidas & Alimentos e bebidas & 2 \\
\hline 4 & Antropologia & Antropologia & 1 \\
\hline \multirow[t]{2}{*}{5} & Atividades complementares & Atividades complementares & 2 \\
\hline & & Organização de eventos & 1 \\
\hline 6 & Captação de eventos & Captação de eventos & 1 \\
\hline 7 & Cerimonial & Cerimonial & 1 \\
\hline 8 & Comunicação & Introdução às técnicas de comunicação & 1 \\
\hline 9 & Cotidiano nas empresas & Cotidiano nas empresas & 1 \\
\hline 10 & Cultura & Cultura religiosa & 1 \\
\hline \multirow[t]{6}{*}{11} & Direito & Direito fiscal e alfandegário & 1 \\
\hline & & Direitos do consumidor & 1 \\
\hline & & Legislação ambiental & 1 \\
\hline & & Legislação e ética do turismo & 1 \\
\hline & & Legislação turística & 1 \\
\hline & & Noções de direito & 1 \\
\hline 12 & Economia & Economia internacional & 1 \\
\hline 13 & Ecoturismo & Ecoturismo & 1 \\
\hline \multirow[t]{3}{*}{14} & Empreendedorismo & Empreendedorismo & 2 \\
\hline & & Empreendedorismo e negócios turísticos & 1 \\
\hline & & Empreendedorismo em turismo & 1 \\
\hline \multirow[t]{4}{*}{15} & Estágio & Estágio supervisionado & 13 \\
\hline & & Estágio curricular supervisionado & 1 \\
\hline & & Estagio supervisionado em orientação metodológica & 1 \\
\hline & & Estágio supervisionado profissional & 2 \\
\hline & Estudos & Estudos complementares & 1 \\
\hline & & Estudos independentes & 1 \\
\hline & & Estudos turísticos & 1 \\
\hline & & Estudos turísticos brasileiros & 1 \\
\hline \multirow[t]{2}{*}{17} & Ética & Ética & 1 \\
\hline & & Ética profissional & 1 \\
\hline 18 & Eventos & Eventos & 1 \\
\hline 19 & Fundamentos do urbanismo & Fundamentos do urbanismo & 1 \\
\hline 20 & Geografia & Geografia aplicada ao turismo & 1 \\
\hline 21 & Gerência e gestão & Gerência de recursos humanos & 1 \\
\hline
\end{tabular}




\begin{tabular}{|c|c|c|c|}
\hline & & Gestão da qualidade dos serviços turísticos & 1 \\
\hline & & Gestão de destinos turísticos & 1 \\
\hline & & Gestão de empreendimentos turísticos & 1 \\
\hline & & Gestão de empresas turísticas & 1 \\
\hline & & Gestão de recursos humanos em turismo & 1 \\
\hline & & Gestão em eventos & 1 \\
\hline & & Gestão geral & 1 \\
\hline & & Gestão mercadológica no turismo & 1 \\
\hline 22 & 2 Governança e lavanderia & Governança e lavanderia & 1 \\
\hline 23 & 3 Higiene e segurança no trabalho & Higiene e segurança no trabalho & 1 \\
\hline 24 & 4 História & História da arte & 1 \\
\hline 25 & 5 Hospedagem & Hospedagem & 1 \\
\hline 26 & 6 Língua estrangeira & Espanhol & 3 \\
\hline & & Língua inglesa & 3 \\
\hline 27 & 7 Marketing & Marketing turistico & 4 \\
\hline & & Marketing de destinações turísticas & 1 \\
\hline 28 & 8 Meios de hospedagem & Meios de hospedagem & 2 \\
\hline 29 & 9 Metodologia & Metodologia científica & 1 \\
\hline & & Metodologia de pesquisa aplicada ao turismo & 1 \\
\hline 30 & Monografia & Monografia & 2 \\
\hline 31 & 1 Orçamento empreendimentos turísticos & Orçamento empreendimentos turísticos & 1 \\
\hline 32 & 2 Orientação & Orientação de estágio supervisionado & 1 \\
\hline & & Orientação metodológica & 2 \\
\hline 33 & \begin{tabular}{|l|l}
3 & Planejamento \\
\end{tabular} & Planej. e org. De projeto turístico & 1 \\
\hline & & Planejamento e desenvolvimento de hotéis & 1 \\
\hline & & Planejamento e organização de eventos & 3 \\
\hline & & Planejamento e organização do turismo & 5 \\
\hline & & Planejamento turístico & 1 \\
\hline & & Plano de desenvolvimento turístico do município & 1 \\
\hline 34 & 4 Política & Política turística brasileira & 1 \\
\hline 35 & 5 Prática profissional & Prática profissional: estágio & 1 \\
\hline 36 & 6 Produção & Produção de roteiros turísticos & 1 \\
\hline & & Produção e comercialização de roteiros turísticos & 1 \\
\hline & & Produtos e roteiros turísticos & 1 \\
\hline 37 & 7 Projeto & Avaliação e elaboração de projetos turísticos (TCC) & 1 \\
\hline & & Desenvolvimento de projetos ecoturísticos & 1 \\
\hline & & Desenvolvimento de projetos turísticos & 1 \\
\hline & & Elaboração e análises de projetos turísticos & 1 \\
\hline & & Estudo de viabilidades de projetos turísticos & 1 \\
\hline & & Projeto & 1 \\
\hline & & Projeto comunitário & 1 \\
\hline & & Projeto de conclusão de curso & 1 \\
\hline & & Projeto experimental & 3 \\
\hline & & Projeto final de curso & 1 \\
\hline & & Projetos turísticos & 2 \\
\hline & & Projetos turísticos: trabalho de conclusão de curso & 2 \\
\hline 38 & 8 Psicologia & Psicologia social das organizações & 1 \\
\hline & & Psicologia social aplicada ao turismo & 1 \\
\hline 39 & 9 Qualidade & Qualidade nos serviços & 1 \\
\hline 40 & Relações & Relações internacionais & 1 \\
\hline & & Relações públicas aplicada ao turismo & 1 \\
\hline & & Relações públicas e comunicação & 1 \\
\hline & & Relações públicas em turismo & 1 \\
\hline 41 & 1 Saúde e segurança na atividade turística & Saúde e segurança na atividade turística & 1 \\
\hline 42 & 2 Seminário & Seminário & 1 \\
\hline 43 & 3 Trabalho de conclusão de curso-TCC & Trabalho de conclusão de curso-TCC & 2 \\
\hline
\end{tabular}




\begin{tabular}{|l|l|l|c|}
\hline 44 & Técnicas & Técnica publicitária & 1 \\
\hline & & Técnicas e serviços de comunicação e transportes & 1 \\
\hline 45 & Teoria & Técnicas publicitárias em turismo & 1 \\
\hline & & Teoria prática. Guia tur. / liderança & 1 \\
\hline & & Teoria do lazer e recreação & 1 \\
\hline 46 & Tópicos & Teoria e prática hoteleiras & 1 \\
\hline & & Tópicos especiais & 3 \\
\hline 47 & Transportes & Tópicos especiais em turismo & 2 \\
\hline 48 & Turismo & Transportes & 1 \\
\hline & & Tur. e licenc. Urbano-ambiental & 1 \\
\hline & & Turismo contemporâneo & 1 \\
\hline & & Turismo e cultura & 1 \\
\hline
\end{tabular}


ANEXOS 


\author{
MINISTÉRIO DA EDUCAÇÃO \\ CONSELHO NACIONAL DE EDUCAÇÃO \\ CÂMARA DE EDUCAÇÃO SUPERIOR
}

INTERESSADO: Conselho Nacional de Educação / Câmara de Educação Superior - UF: DF

ASSUNTO: Diretrizes Curriculares Nacionais dos cursos de graduação Turismo e Hotelaria,

RELATORES CONSELHEIROS: José Carlos Almeida da Silva e Lauro Ribas Zimmer

PROCESSO No: 23001.000074/2002-10

PARECER N ${ }^{\circ}$ CES/CNE 0146/2002

COLEGIADO: CES APROVADO EM: 03/04/2002

I - RELATÓRIO

A Lei de Diretrizes e Bases da Educação Nacional 4.024/61, em seu art. $9^{\circ}$, posteriormente também a Lei de Reforma Universitária 5.540/68, no art. 26, estabeleciam que ao então Conselho Federal de Educação incumbia a fixação dos currículos mínimos dos cursos de graduação, válidos para todo o País, os quais foram concebidos com os objetivos a seguir elencados, dentre outros:

1)facilitar as transferências entre instituições, de uma localidade para outra, ou até na mesma localidade, sem causar delonga na integralização do curso ou "em perda de tempo", com a não contabilização dos créditos realizados na instituição de origem, como se vê no art. 100 da Lei 4.024/61, com a redação dada pela Lei 7.037/82;

2)fornecer diploma profissional, assegurando o exercício das prerrogativas e direitos da profissão, como rezava o art. 27 da Lei 5.540/68;

3)assegurar uniformidade mínima profissionalizante a todos quantos colassem grau profissional, diferenciados apenas em relação às disciplinas complementares e optativas, tudo como se observa, quando das transferências e do aproveitamento de estudos realizados, no art. $2^{\circ}$ da Resolução CFE 12/84, segundo a qual as matérias componentes do currículo mínimo de qualquer curso superior cursadas com aproveitamento em instituição autorizada eram automaticamente reconhecidas na instituição de destino, inobstante alguma variação de carga horária a menor, à razão de aproximadamente 25\%;

4)permitir-se, na duração de cursos, de forma determinada, a fixação de tempo útil mínimo, médio ou máximo, desde que esses tempos não significassem redução de qualidade face à redução ou prorrogação prejudicial da duração do curso, ainda que com o mesmo número de créditos;

5)observar normas gerais válidas para o País, de tal maneira que ao estudante se assegurasse, como "igualdade de oportunidades", o mesmo estudo, com os mesmos conteúdos e até com a mesma duração e denominação, em qualquer instituição. Os atos normativos que fixavam os currículos mínimos também indicavam sob que denominação disciplinas ou matérias deveriam ser alocadas no currículo, para se manter o padrão unitário, uniforme, de oferta curricular nacional. 
Por estas e outras razões, serviram os currículos mínimos para estabelecer um patamar uniforme entre cursos de instituições diferentes, inclusive quanto à carga horária obrigatória, que prevalecia sobre a complementar e optativa, além da inexigência, em alguns cursos, de implementação profissional através de estágio.

O modelo de currículos mínimos implicava elevado detalhamento de disciplinas e cargas horárias, a serem obrigatoriamente cumpridas, sob pena de não ser reconhecido o curso, ou até não ser autorizado quando de sua proposição, o que inibia as instituições de inovar projetos pedagógicos, na concepção dos cursos existentes, para atenderem às exigências de diferentes ordens.

Ademais, os currículos mínimos profissionalizantes se constituíam numa exigência para uma suposta igualdade entre os profissionais de diferentes instituições, quando obtivessem os seus respectivos diplomas, com direito de exercer a profissão, por isto que se caracterizavam pela rigidez na sua configuração formal, verdadeira "grade curricular" dentro da qual os alunos deveriam estar aprisionados, submetidos até aos mesmos conteúdos previamente detalhados e obrigatoriamente repassados, independentemente de contextualização, com a visível redução da liberdade de as instituições organizarem seus cursos de acordo com o projeto pedagógico específico ou de mudarem essas atividades curriculares e seus conteúdos segundo as novas exigências da ciência, da tecnologia e do meio.

Desta forma, os currículos mínimos profissionalizantes, rigidamente concebidos na norma, para serem observados nas instituições, não mais permitiam o alcance da qualidade desejada segundo a sua contextualização no espaço e tempo. Ao contrário, inibiam a inovação e a diversificação na preparação ou formação do profissional apto para a adaptabilidade!...

Com a publicação da Lei 9.131 , de 24/11/95, o art. $9^{\circ}$, $\S 2^{\circ}$, alínea "c", conferiu à Câmara de Educação Superior do Conselho Nacional de Educação a competência para "a elaboração do projeto de Diretrizes Curriculares Nacionais - DCN, que orientarão os cursos de graduação, a partir das propostas a serem enviadas pela Secretaria de Educação Superior do Ministério da Educação ao CNE", tal como viria a estabelecer o inciso VII do art. $9^{\circ}$ da nova LDB 9.394/96, de 20/12/96, publicada em 23/12/96.

A CES/CNE, posteriormente, aprovou o Parecer 776/97, no qual estabelece que as Diretrizes Curriculares Nacionais devem:

a)se constituir em orientações para a elaboração dos currículos;

b)ser respeitadas por todas as IES; e

c)assegurar a flexibilidade e a qualidade da formação oferecida aos estudantes.

Além disto, o Parecer em tela evidencia que as Diretrizes Curriculares Nacionais devem observar os seguintes princípios:

1.assegurar às instituições de ensino superior ampla liberdade na composição da carga horária a ser cumprida para a integralização dos currículos, assim como na especificação das unidades de estudos a serem ministradas;

2.indicar os tópicos ou campos de estudos e demais experiências de ensino-aprendizagem que comporão os currículos, evitando ao máximo a fixação de conteúdos específicos com cargas horárias pré-determinadas, os quais não poderão exceder $50 \%$ da carga horária total dos cursos;

3.evitar o prolongamento desnecessário da duração dos cursos de graduação; 
4.incentivar uma sólida formação geral, necessária para que o futuro graduado possa vir a superar os desafios de renovadas condições de exercício profissional e de produção do conhecimento, permitindo variados tipos de formação e habilitações diferenciadas em um mesmo programa;

5.estimular práticas de estudos independentes, visando uma progressiva autonomia profissional e intelectual do aluno;

6.encorajar o reconhecimento de conhecimentos, habilidades e competências adquiridas fora do ambiente escolar, inclusive as que se refiram à experiência profissional julgada relevante para a área de formação considerada;

7.fortalecer a articulação da teoria com a prática, valorizando a pesquisa individual e coletiva, assim como os estágios e a participação em atividades de extensão, as quais poderão ser incluídas como parte da carga horária;

8.incluir orientações para a condução de avaliações periódicas que utilizem instrumentos variados e sirvam para informar a docentes e discentes a cerca do desenvolvimento das atividades didáticas.

Por sua vez, a SESu/MEC publicou o Edital 004/97, convocando as instituições de ensino superior para que encaminhassem propostas para a elaboração das diretrizes curriculares dos cursos de graduação, a serem sistematizadas pelas Comissões de Especialistas de Ensino de cada área.

O Edital 004/97 e o decorrente Modelo de Enquadramento das Propostas de Diretrizes Curriculares ensejaram alto nível de participação de amplos segmentos socais e institucionais. Com efeito, é bom frisar que deste procedimento não somente advieram ricas e ponderáveis contribuições da sociedade, das universidades, das faculdades, de organizações profissionais, de organizações docentes e discentes, enfim, da comunidade acadêmica e científica, e com a ampla participação dos setores públicos e privados em seminários, fóruns e encontros de debates, como também resultou na legitimação, na sua origem, dessas propostas trabalhadas pelo MEC/SESu, agora sob a análise desta Câmara por curso.

Estabeleceu-se, então, um roteiro, de natureza metodológica, por isto mesmo flexível, de acordo com as discussões e encaminhamentos das Propostas das Diretrizes Curriculares Nacionais de cada curso, sistematizando-as segundo as grandes áreas do conhecimento, nas quais os cursos se situam, resguardando, conseqüentemente, toda uma congruência daquelas Diretrizes por curso e dos paradigmas estabelecidos para a sua elaboração.

Quanto aos paradigmas das Diretrizes Curriculares Nacionais, cumpre, de logo, destacar que elas objetivam "servir de referência para as instituições na organização de seus programas de formação, permitindo flexibilidade e priorização de áreas de conhecimento na construção dos currículos plenos. Devem induzir à criação de diferentes formações e habilitações para cada área do conhecimento, possibilitando ainda definirem múltiplos perfis profissionais, garantindo uma maior diversidade de carreiras, promovendo a integração do ensino de graduação com a pósgraduação, privilegiando, no perfil de seus formandos, as competências intelectuais que reflitam a heterogeneidade das demandas sociais".

Desta forma, para todo e qualquer curso de graduação, as Diretrizes Curriculares Nacionais recomendaram:

1.conferir maior autonomia às instituições de ensino superior na definição dos currículos de seus cursos, a partir da explicitação das competências e das habilidades que se deseja desenvolver, através da organização de um modelo pedagógico capaz de adaptar-se à dinâmica das demandas da sociedade, em que a graduação passa a constituir-se numa etapa de formação inicial no processo contínuo da educação permanente; 
2.propor uma carga horária mínima em horas que permita a flexibilização do tempo de duração do curso de acordo com a disponibilidade e esforço do aluno;

3.otimizar a estruturação modular dos cursos, com vistas a permitir um melhor aproveitamento dos conteúdos ministrados, bem como a ampliação da diversidade da organização dos cursos, integrando a oferta de cursos seqüenciais, previstos no inciso I do art. 44 da LDB;

4.contemplar orientações para as atividades de estágio e demais atividades que integrem o saber acadêmico à prática profissional, incentivando o reconhecimento de habilidades e competências adquiridas fora do ambiente escolar; e

5.contribuir para a inovação e a qualidade do projeto pedagógico do ensino de graduação, norteando os instrumentos de avaliação.

Posteriormente, a Câmara de Educação Superior do Conselho Nacional de Educação, ao aprovar o Parecer 583/2001, tomou como referência o Parecer 776/97 dessa mesma Câmara, o Edital 4, de dezembro de 1997, do MEC/SESu, e o Plano Nacional de Educação, Lei 10.172, de janeiro de 2001, que definiu, dentre os objetivos e metas: “... Estabelecer, em nível nacional, diretrizes curriculares que assegurem a necessária flexibilidade e diversidade nos programas oferecidos pelas diferentes instituições de ensino superior, de forma a melhor atender às necessidades diferenciais de suas clientelas e às peculiaridades das regiões nas quais se inserem...". Ao aprovar, portanto, diretrizes comuns a todos os cursos, a intenção é garantir a flexibilidade, a criatividade e a responsabilidade das instituições ao elaborarem suas propostas curriculares.

De tudo quanto exposto até esta parte, poder-se-á estabelecer as principais diferenças entre Currículo Mínimo e Diretrizes Curriculares Nacionais, com o propósito de mostrar os avanços e as vantagens proporcionadas por estas últimas:

1)enquanto os Currículos Mínimos estavam comprometidos com a emissão de um diploma para o exercício profissional, as Diretrizes Curriculares Nacionais não se vinculam a diploma e a exercício profissional, pois os diplomas, de acordo com o art. 48 da LDB, se constituem prova, válida nacionalmente, da formação recebida por seus titulares;

2)enquanto os Currículos Mínimos encerravam a concepção do exercício do profissional, cujo desempenho resultaria especialmente das disciplinas ou matérias profissionalizantes, enfeixadas em uma grade curricular, com os mínimos obrigatórios fixados em uma resolução por curso, as Diretrizes Curriculares Nacionais concebem a formação de nível superior como um processo contínuo, autônomo e permanente, com uma sólida formação básica e uma formação profissional fundamentada na competência teórico-prática, de acordo com o perfil de um formando adaptável às novas e emergentes demandas;

3)enquanto os Currículos Mínimos inibiam a inovação e a criatividade das instituições, que não detinham liberdade para reformulações naquilo que estava, por Resolução do CFE, estabelecido nacionalmente como componentes curriculares e até com detalhamento de conteúdos obrigatórios, as Diretrizes Curriculares Nacionais ensejam a flexibilização curricular e a liberdade de as instituições elaborarem seus projetos pedagógicos para cada curso segundo uma adequação às demandas sociais e do meio e aos avanços científicos e tecnológicos, conferindoIhes uma maior autonomia na definição dos currículos plenos dos seus cursos;

4)enquanto os Currículos Mínimos muitas vezes atuaram como instrumento de transmissão de conhecimentos e de informações, inclusive prevalecendo interesses corporativos responsáveis por obstáculos no ingresso no mercado de trabalho e por desnecessária ampliação ou prorrogação na duração do curso, as Diretrizes Curriculares Nacionais orientam-se na direção de uma sólida formação básica, preparando o futuro graduado para enfrentar os desafios das rápidas transformações da sociedade, do mercado de trabalho e das condições de exercício profissional; 
5)enquanto o Currículo Mínimo profissional pretendia, como produto, um profissional "preparado", as Diretrizes Curriculares Nacionais pretendem preparar um profissional adaptável a situações novas e emergentes;

6)enquanto os Currículos Mínimos, comuns e obrigatórios em diferentes instituições, se propuseram mensurar desempenhos profissionais no final do curso, as Diretrizes Curriculares Nacionais se propõem ser um referencial para a formação de um profissional em permanente preparação, visando uma progressiva autonomia profissional e intelectual do aluno, apto a superar os desafios de renovadas condições de exercício profissional e de produção de conhecimento;

7)enquanto os Currículos Mínimos eram fixados para uma determinada habilitação profissional, assegurando direitos para o exercício de uma profissão regulamentada, as Diretrizes Curriculares Nacionais devem ensejar variados tipos de formação e habilitações diferenciadas em um mesmo programa.

II - MÉRITO

Como já assinalado anteriormente, a LDB 4.024/61, em seu art. $9^{\circ}$, seguido pelo art. 26 da Lei 5.540/68, conferiu ao então Conselho Federal de Educação a competência para fixar os currículos dos cursos de graduação, o que ensejou a obrigatória observância dos denominados currículos mínimos profissionais de cada curso de graduação, inclusive de suas habilitações, mediante resoluções daquele Colegiado, válidas nacionalmente, para qualquer sistema de ensino, resultando para as instituições apenas a escolha de componentes curriculares complementares e a listagem para os alunos de disciplinas optativas, e, quando concebessem cursos experimentais, inovando e criando respostas para situações localizadas, ainda assim só poderiam colocá-los em funcionamento após prévia aprovação dos currículos e autorização dos cursos (art. 104 - LDB 4.024/61).

Desta forma, engessados os currículos mínimos e direcionados para o exercício profissional, com direitos e prerrogativas assegurados pelo diploma, nem sempre o currículo pleno significou a plenitude de uma coerente e desejável proposta pedagógica, contextualizada, que se ajustasse permanentemente às emergentes mudanças sociais, tecnológicas e científicas, por isto que os graduados, logo que colassem grau, já se encontravam defasados em relação ao desempenho exigido no novo contexto, urgindo preparação específica para o exercício da ocupação ou profissão.

Nesse quadro, era mesmo necessária uma espécie de "desregulamentação", de flexibilização e de uma contextualização das instituições de ensino superior, que atendessem mais rapidamente, e sem as amarras anteriores, à sua dimensão política, isto é, pudessem as instituições de ensino superior assumir a responsabilidade de se constituírem respostas às efetivas necessidades sociais - demanda social ou necessidade social -, expressões estas que soam com a mesma significação da sua correspondente "exigência do meio" contida no art. 53, inciso IV, da atual LDB 9.394/96.

Sendo as instituições caixa de ressonância das expectativas sociais, ali ecoava a demanda reprimida no mercado de trabalho, no avanço tecnológico e científico, ficando, não raro, impossibilitadas de implementar qualquer projeto com que ousassem inovar em matéria curricular, salvo se, nos termos do então art. 104 da LDB 4.024/61, tivessem o destemor, nem sempre reconhecido, de propor cursos experimentais com currículos estruturados como experiência pedagógica, porque não se enquadravam nos currículos mínimos vigentes, sabendo-se que, como se disse, mesmo assim estavam eles condicionados à prévia aprovação pelo Conselho Federal de Educação, sob pena de infringência à lei.

A Constituição Federal de 1988, com indiscutíveis avanços, prescreveu, em seu art. 22, inciso XXIV, que a União editaria, como editou, em 20 de dezembro de 1996, a nova LDB 9.394/96, contemplando, na nova ordem jurídica, um desafio para a educação brasileira: as instituições assumirão a ousadia da criatividade e da inventividade, na flexibilização com que a LDB marcou a autonomia das instituições e dos sistemas de ensino, em diferentes níveis. 
No caso concreto das instituições de ensino superior, estas responderão necessariamente pelo padrão de qualidade na oferta de seus cursos, o que significa, no art. 43, preparar profissionais aptos para a sua inserção no campo do desenvolvimento, em seus diversos segmentos, econômicos, culturais, políticos, científicos, tecnológicos etc. Disto resultou o imperioso comprometimento das instituições formadoras de profissionais e de recursos humanos com as mudanças iminentes, no âmbito político, econômico e cultural, e até, a cada momento, no campo das ciências e da tecnologia, nas diversas áreas do conhecimento, devendo, assim, a instituição estar apta para constituir-se resposta a essas exigências.

Certamente, adviria uma nova concepção da autonomia universitária e de responsabilização das instituições não-universitárias, em sua harmonização com essas mutações contínuas e profundas, de tal forma que ou as instituições se revelam com potencial para atender "às exigências do meio", ou elas não se engajarão no processo de desenvolvimento e se afastarão do meio, porque não poderão permanecer "preparando" recursos humanos "despreparados" ou sem as aptidões necessárias ao permanente e periódico ajustamento a essas mudanças. Com efeito, repita-se, não se cogita mais do profissional "preparado", mas do profissional apto às mudanças e, portanto, adaptável.

Isto significa um marco histórico, porque, em matéria de concepção pedagógica do processo educativo e, conseqüentemente, das concepções das ações pelas quais a educação e o ensino venham a efetivar-se, sem dúvida haveria de ser repensada a elaboração dos currículos dos cursos de qualquer grau ou nível, especialmente os de grau superior, convocadas que estavam todas as instituições da comunidade para exercerem uma ação conjugada, harmônica e cooperativa, com o Poder Público e com outras instituições, como se verifica no art. 205 da Constituição Federal ("com a colaboração da sociedade") e no art. 211 ("em regime de colaboração"), para resgatar a educação dos percalços em que se encontrava e ante os desafios acenados em novos horizontes da história brasileira e do mundo.

Por isto, a nova LDB (9.131/95 e 9.394/96), revogando parcialmente a anterior, teria de firmar diretrizes básicas para esse novo desafio, promovendo a flexibilização na elaboração dos currículos dos cursos de graduação, retirando-lhes as amarras da concentração, da inflexibilidade dos currículos mínimos profissionalizantes nacionais, que são substituídos por "Diretrizes Curriculares Nacionais".

Desta forma, foram estabelecidas, a partir das orientações gerais contidas nos Pareceres CES/CNE 776/97 e 583/2001, bem como nos desdobramentos decorrentes do Edital 004/97SESu/MEC, as Diretrizes Curriculares Nacionais e as Diretrizes Curriculares Gerais dos Cursos de Graduação, por curso, considerado segundo a respectiva área de conhecimento, observando-se os paradigmas, níveis de abordagem, perfil do formando, competências e habilidades, habilitações, conteúdos ou tópicos de estudos, duração dos cursos, atividades práticas e complementares, aproveitamento de habilidades e competências extracurriculares, interação com a avaliação institucional como eixo balizador para o credenciamento e avaliação da instituição, para a autorização e reconhecimento de cursos, bem como suas renovações, adotados indicadores de qualidade, sem prejuízo de outros aportes considerados necessários.

Neste passo, não é demais repetir que tudo foi concebido com o propósito de que se pudesse estabelecer um perfil do formando no qual a formação de nível superior se constituísse em processo contínuo, autônomo e permanente, com uma sólida formação básica e uma formação profissional fundamentada na competência teórico-prática, observada a flexibilização curricular, autonomia e a liberdade das instituições de inovar seus projetos pedagógicos de graduação, para o atendimento das contínuas e emergentes mudanças para cujo desafio o futuro formando deverá estar apto.

Cumpre agora, portanto, a esta Comissão analisar e relatar perante a Câmara de Educação Superior, para sua elevada deliberação colegiada, as propostas das Diretrizes Curriculares Nacionais dos cursos de graduação em Direito, Ciências Econômicas, Administração, Ciências Contábeis, Turismo, Hotelaria, Secretariado Executivo, Música, Dança, Teatro e Design, cujas especificações e detalhamento atenderam à metodologia adotada, especialmente quanto ao perfil 
desejado do formando, às competências/habilidades/atitudes, habilitações e ênfases, aos conteúdos curriculares, à organização dos cursos, aos estágios e atividades complementares e ao acompanhamento e avaliação.

Este Parecer, portanto, contempla as orientações das Comissões de Especialistas e as da SESU/MEC, as quais, na sua grande maioria, foram acolhidas e reproduzidas na sua totalidade, não só por haver concordância com as idéias suscitadas no conjunto do ideário concebido, mas também como forma de reconhecer e valorizar a legitimidade do processo coletivo e participativo, que deu origem à elaboração dos documentos sobre Diretrizes Curriculares Gerais dos Cursos de Graduação, cujas propostas foram encaminhadas pela SESu/MEC para deliberação deste Colegiado.

Contudo, vale salientar que diferenças nas formas de visão e de concepção do processo educativo levaram esta Comissão a não acolher plenamente todas as propostas apresentadas, razão pela qual alguns pontos são contraditados com a devida fundamentação.

Finalmente, como se observará nos itens subseqüentes, esta Comissão adotou como metodologia, para efeito deste Parecer, analisar o conjunto das Propostas Curriculares Nacionais dos 11 (onze) Cursos de Graduação acima indicados, enfocando-as sob dois segmentos norteadores: a) Diretrizes Comuns aos Cursos Relatados; b) Diretrizes Específicas por Curso.

\subsection{Diretrizes Comuns aos Cursos Relatados}

Sob este título, entendeu a Comissão que deveria enfeixar balizamentos comuns a serem observados pelas instituições de ensino superior quanto aos 11 (onze) cursos sobre cujas Diretrizes Gerais se debruçou para o presente relato a ser submetido à deliberação da Câmara de Educação Superior, abrangendo Projeto Pedagógico, Organização Curricular, Estágios e Atividades Complementares, Acompanhamento e Avaliação e Monografia.

\section{-Projeto Pedagógico}

As instituições de ensino superior deverão, na composição dos seus projetos pedagógicos, definir, com clareza, os elementos que lastreiam a própria concepção do curso, o seu currículo pleno e sua operacionalização, destacando-se os seguintes elementos, sem prejuízo de outros:

-objetivos gerais do curso, contextualizados em relação às suas inserções institucional, política, geográfica e social;

-condições objetivas de oferta e a vocação do curso;

-cargas horárias das atividades didáticas e da integralização do curso;

-formas de realização da interdisciplinaridade;

-modos de integração entre teoria e prática;

-formas de avaliação do ensino e da aprendizagem;

-modos da integração entre graduação e pós-graduação, quando houver;

-cursos de pós-graduação lato sensu, nas modalidades especialização, integradas e/ou subseqüentes à graduação, e de aperfeiçoamento, de acordo com a evolução das ciências, das tecnologias e das efetivas demandas do desempenho profissional, observadas as peculiaridades de cada área do conhecimento e de atuação, por curso; 
-incentivo à pesquisa, como necessário prolongamento da atividade de ensino e como instrumento para a iniciação científica;

-concepção e composição das atividades de estágio, por curso;

-concepção e composição das atividades complementares;

-oferta de curso seqüenciais e de tecnologia, quando for o caso.

\section{-Organização Curricular}

As instituições de ensino superior, exercitando seu potencial inovador e criativo e da liberdade e flexibilidade que possuem na organização de seus currículos, devem concebê-los de acordo com os regimes acadêmicos que adotarem, a saber: regime seriado anual, regime seriado semestral, sistema de créditos, sistemas modulares ou de módulos acadêmicos, sistema de pré-requisitos e de créditos com matrículas por disciplina, prevendo expressamente a integralização curricular do curso como condição para a sua efetiva conclusão e subseqüente colação de grau, com a distribuição do tempo útil previsto, definido em termos de carga horária, duração ou redução de duração do curso, de tal forma que os alunos tenham a informação do tempo de estudos previsto e das possibilidades de redução ou ampliação desse tempo, preservado sempre o princípio do padrão de qualidade.

Acrescente-se que, recentemente, a CES/CNE aprovou o Parecer 100/2002 e seu anexo Projeto de Resolução, em 13/03/2002, contendo parâmetros relacionados com a duração dos cursos, com a carga horária e com percentuais para atividades práticas e estágio, tudo de acordo com a organização curricular de cada curso e o regime acadêmico adotado, excetuando-se as licenciaturas plenas e os cursos de formação docente, que têm disciplinamento próprio.

\section{·Estágios e Atividades Complementares}

O Estágio Curricular, Supervisionado, deve ser concedido como conteúdo curricular implementador do perfil do formando, consistindo numa atividade obrigatória, mas diversificada, tendo em vista a consolidação prévia dos desempenhos profissionais desejados, segundo as peculiaridades de cada curso de graduação.

Pelo seu caráter implementador de desempenhos profissionais antes mesmo de se considerar concluído o curso, é necessário que, à proporção que os resultados do estágio forem sendo verificados, interpretados e avaliados, o estagiário esteja consciente do seu atual perfil, naquela fase, para que ele próprio reconheça a necessidade da retificação da aprendizagem, nos conteúdos em que revelara equívocos ou insegurança de domínio, e da própria reprogramação da prática, assegurando-se-lhe, nessa reorientação e reprogramação teórico-prática, o direito subjetivo constitucional ao padrão de qualidade, que se revelará no exercício profissional, já no âmbito das instituições sociais.

As Atividades Complementares, por seu turno, devem possibilitar o reconhecimento, por avaliação, de habilidades e competências do aluno, inclusive adquiridas fora do ambiente escolar, hipóteses em que o aluno alargará o seu currículo com experimentos e vivências acadêmicos, internos ou externos ao curso, não se confundindo estágio curricular, supervisionado, com a amplitude e a rica dinâmica das Atividades Complementares.

As Atividades Complementares, assim, se orientam a estimular a prática de estudos independentes, transversais, opcionais, de interdisciplinaridade, de permanente e contextualizada atualização profissional específica, sobretudo nas relações com o mundo do trabalho, estabelecidas ao longo do curso, notadamente integrando-as às diversas peculiaridades regionais e culturais. 
Nesse sentido, as Atividades Complementares podem incluir projetos de pesquisa, monitoria, iniciação científica, projetos de extensão, módulos temáticos, seminários, simpósios, congressos, conferências, além de disciplinas oferecidas por outras instituições de ensino ou de regulamentação e supervisão do exercício profissional, ainda que esses conteúdos não estejam previstos no currículo pleno de uma determinada instituição mas nele podem ser aproveitados porque circulam em um mesmo currículo, de forma interdisciplinar, e se integram com os demais conteúdos realizados.

Enfim, as atividades de extensão, previstas no art. 44, inciso IV, da LDB 9.394/96, cuja finalidade básica, dentre outras, consiste em propiciar à comunidade o estabelecimento de uma relação de reciprocidade com a instituição, podem ser integradas nas Atividades Complementares, enriquecedoras e implementadoras do próprio perfil do formando, sem que se confundam com Estágio Curricular, Supervisionado.

\section{·Acompanhamento e Avaliação}

As IES deverão adotar formas específicas e alternativas de avaliação, internas e externas, sistemáticas, envolvendo todos quantos se contenham no processo do curso, centradas em aspectos considerados fundamentais para a identificação do perfil do formando, estando presentes o desempenho da relação professor $x$ aluno, a parceria do aluno para com a instituição e o professor.

Assim, as instituições não somente deverão adotar práticas pedagógicas e métodos de ensino/aprendizagem inovadores, direcionados à garantia da qualidade do curso, como também deverão adotar procedimentos alternativos de avaliação que favoreçam a compreensão da totalidade do curso, consolidando o perfil desejado do formando, aferindo também a importância do caráter inter e multidisciplinar das ações didáticas e pedagogicamente estruturadas, inclusive ensejando interface da graduação com a pós-graduação sob diferentes mecanismos, em especial com estímulo à pesquisa, o incentivo à produção científica e a inserção na comunidade sob as diversas formas ou programas de extensão.

Importante fator para a avaliação das instituições é a produção que elas podem colocar à disposição da sociedade e de todos quantos se empenhem no crescimento e no avanço da ciência e da tecnologia. Com efeito, a produção que uma instituição divulga, publica, socializa, certamente será um forte e ponderável indicador para o acompanhamento e avaliação sobre a instituição, sobre o curso e para os alunos em particular que, durante o próprio curso, já produzem, como reflexo da consciência que possuem quanto ao desenvolvimento de suas potencialidades.

\section{-Monografia/Trabalho de Conclusão de Curso}

No conjunto das Diretrizes Curriculares Nacionais e das Diretrizes Curriculares Gerais dos Cursos de Graduação, a Monografia/Trabalho de Conclusão de Curso vêm sendo concebidos ora como um conteúdo curricular opcional, ora como obrigatório.

Nos cursos objeto do presente Parecer, a Monografia se insere no eixo dos conteúdos curriculares opcionais, cuja adequação aos currículos e aos cursos ficará à cargo de cada instituição que assim optar, por seus colegiados superiores acadêmicos, em face do seguinte entendimento:

1)a graduação passa a ter um papel de formação inicial no processo contínuo de educação, que é também inerente ao próprio mundo do trabalho e da permanente capacitação profissional, isto é, do profissional apto ao enfrentamento dos desafios suscitados pelas mudanças iminentes à conclusão do curso ou emergentes e conjunturais;

2)os currículos passam a ser configurados e reconfigurados dentro de um modelo capaz de adaptar-se às dinâmicas condições do perfil desejado do formando, exigido pela sociedade, com todas as contingências que envolvem a história humana, suscitando um contínuo aprimorar-se; 
3)a monografia se constitui em instrumental mais apropriado aos cursos de pós-graduação lato sensu que os formandos ou egressos venham a realizar, indispensáveis ao seu desempenho profissional qualitativo, especialmente face às inovações científicas e tecnológicas, em diferentes áreas;

4)a monografia, pelas suas peculiaridades, deve ter, em cada instituição que por ela opte expressamente, regulamentação própria, com critérios, procedimentos e mecanismos de avaliação bastante explícitos, bem como diretrizes técnicas relacionadas com a sua elaboração.

\subsection{Diretrizes Específicas por Curso Relatado}

Sob este tópico serão tratados os aspectos peculiares a cada curso, abrangendo Perfil Desejado do Formando, as Competências e Habilidades, os Conteúdos Curriculares e, quando necessário, um tópico sobre Considerações Finais.

\subsection{1.......}

3.2.2.........

3.2.3........

$3.2 .4 \ldots \ldots$

\subsubsection{Curso de Graduação em Turismo}

\section{-Perfil Desejado do Formando}

Quanto ao perfil desejado, o curso de graduação em Turismo deverá oportunizar a formação de um profissional apto a atuar em mercados altamente competitivos e em constante transformação, cujas opções possuem um impacto profundo na vida social, econômica e no meio ambiente, exigindo uma formação ao mesmo tempo generalista, no sentido tanto do conhecimento geral, das ciências humanas, sociais, políticas e econômicas, como também de uma formação especializada, constituída de conhecimentos específicos, sobretudo nas áreas culturais, históricas, ambientais, antropológicas, de Inventário do Patrimônio Histórico e Cultural, bem como o agenciamento, organização e gerenciamento de eventos e a administração do fluxo turístico.

\section{-Competências e Habilidades}

O curso de graduação em Turismo deve possibilitar formação profissional que revele, pelo menos, as seguintes competências e habilidades:

-compreensão das políticas nacionais e regionais sobre turismo;

-utilização de metodologia adequada para o planejamento das ações turísticas, abrangendo projetos, planos e programas, com os eventos locais, regionais, nacionais e internacionais;

-positiva contribuição na elaboração dos planos municipais e estaduais de turismo;

-domínio das técnicas indispensáveis ao planejamento e à operacionalização do Inventário Turístico, detectando áreas de novos negócios e de novos campos turísticos e de permutas culturais;

-domínio e técnicas de planejamento e operacionalização de estudos de viabilidade econômicofinanceira para os empreendimentos e projetos turísticos;

-adequada aplicação da legislação pertinente; 
-planejamento e execução de projetos e programas estratégicos relacionados com empreendimentos turísticos e seu gerenciamento;

-intervenção positiva no mercado turístico com sua inserção em espaços novos, emergentes ou inventariados;

-classificação, sobre critérios prévios e adequados, de estabelecimentos prestadores de serviços turísticos, incluindo meios de hospedagens, transportadoras, agências de turismo, empresas promotoras de eventos e de outras áreas, postas com segurança à disposição do mercado turístico e de sua expansão;

-domínios de técnicas relacionadas com a seleção e avaliação de informações geográficas, históricas, artísticas, esportivas, recreativas e de entretenimento, folclóricas, artesanais, gastronômicas, religiosas, políticas e outros traços culturais, como diversas formas de manifestação da comunidade humana;

-domínio de métodos e técnicas indispensáveis ao estudo dos diferentes mercados turísticos, identificando os prioritários, inclusive para efeito de oferta adequada a cada perfil do turista;

-comunicação interpessoal, intercultural e expressão correta e precisa sobre aspectos técnicos específicos e da interpretação da realidade das organizações e dos traços culturais de cada comunidade ou segmento social;

-utilização de recursos turísticos como forma de educar, orientar, assessorar, planejar e administrar a satisfação das necessidades dos turistas e das empresas, instituições públicas ou privadas, e dos demais segmentos populacionais;

-domínio de diferentes idiomas que ensejem a satisfação do turista em sua intervenção nos traços culturais de uma comunidade ainda não conhecida;

-habilidade no manejo com a informática e com outros recursos tecnológicos;

-integração nas ações de equipes interdisciplinares e multidisciplinares interagindo criativamente nos diferentes contextos organizacionais e sociais;

-compreensão da complexidade do mundo globalizado e das sociedades pós-industriais, onde os setores de turismo e entretenimento encontram ambientes propícios para se desenvolverem;

-profunda vivência e conhecimento das relações humanas, de relações públicas, das articulações interpessoais, com posturas estratégicas para o êxito de qualquer evento turístico;

-conhecimentos específicos e adequado desempenho técnico-profissional, com humanismo, simplicidade, segurança, empatia e ética.

\section{-Conteúdos Curriculares}

Os cursos de graduação em Turismo deverão contemplar, em seus projetos pedagógicos e em sua organização curricular, conteúdos que atendam aos seguintes eixos interligados de formação:

I -Conteúdos Básicos: estudos relacionados com os aspectos Sociológicos, Antropológicos, Históricos, Filosóficos, Geográficos, Culturais e Artísticos, que conformam as sociedades e suas diferentes culturas;

II -Conteúdos Específicos: estudos relacionados com a Teoria Geral do Turismo, Teoria da Informação e da Comunicação, estabelecendo ainda as relações do Turismo com a 
Administração, o Direito, a Economia, a Estatística e a Contabilidade, além do domínio de, pelo menos, uma língua estrangeira;

III -Conteúdos Teórico-Práticos: estudos localizados nos respectivos espaços de fluxo turístico, compreendendo visitas técnicas, inventário turístico, laboratórios de aprendizagem e de estágios.

\subsubsection{Curso de Graduação em Hotelaria}

O curso de graduação em Hotelaria, na modalidade bacharelado, terá uma terminalidade segundo a sua concepção curricular e o projeto pedagógico do curso, adequados ao perfil desejado do formando, incluindo até conteúdos curriculares de natureza pedagógica indispensáveis à habilitação para o magistério em cursos de formação profissionalizante ou de Educação Profissional de que trata a Lei de Diretrizes e Bases da Educação Nacional 9.394/96.

\section{-Perfil Desejado do Formando}

Quanto ao perfil desejado, o curso de graduação em Hotelaria deverá oportunizar a formação de um profissional apto a atuar em um mercado altamente competitivo e em constante transformação, com impactos periódicos ou sazonais, segundo as mudanças na vida social, econômica, política, empresarial e organizacional, com ênfase na Gestão e Administração de Hotéis com os mais diversos e importantes aspectos estruturais, infra-estruturais e o seu eficaz e qualitativo funcionamento, de acordo com os diversos segmentos culturais da demanda hoteleira.

\section{-Competências e Habilidades}

O curso de graduação em Hotelaria deve possibilitar a formação profissional que revele, pelo menos, as seguintes competências e habilidades para:

-atuar no planejamento, implantação e gerenciamento de unidades hoteleiras;

-reconhecer e identificar problemas, equacionando soluções, intermediando e coordenando os diferentes níveis do processo de tomada de decisão;

-ajustar-se aos diferentes contextos históricos e suas inter-relações geográficas, sociais, econômicas e turísticas, especialmente para o constante aperfeiçoamento em planejamentos e gestões de empresas hoteleiras;

-adotar, com eficácia, modelos inovadores de gestão;

-integrar-se no grupo hoteleiro e da unidade que gerencia, contribuindo para a ação de equipes interdisciplinares e interagir criativamente face aos diferentes contextos organizacionais e sociais bem como resolver situações com flexibilidade e adaptabilidade diante de problemas e desafios organizacionais;

-comunicar-se em idiomas estrangeiros, principalmente a língua inglesa e a espanhola, manejando também os recursos informatizados e outros equipamentos tecnológicos;

-exercer, com liderança e responsabilidade, o gerenciamento da unidade hoteleira, direcionado ao melhor atendimento ao cliente, usuário;

-implantar planejamento estratégico capaz de assegurar produtividade e competitividade, em mercados de significativas diversificações;

-ajustar, mediante adequada forma de gerenciamento, o funcionamento institucional a novas situações, emergentes, presentes na pluralidade do mercado hoteleiro, da cultura e da demanda 
diferenciada, das expectativas de diferentes pólos turísticos ou em razão de diversos processos de mobilidade social.

\section{.Conteúdos Curriculares}

O curso de graduação em Hotelaria deve direcionar os conteúdos para o perfil desejado do formando, a partir dos seguintes tópicos de estudos interligados:

I -Conteúdos Básicos: estudos relacionados com as Ciências Humanas, com ênfase na Psicologia, Sociologia e na Geografia Física, Humana, Política e Econômica, e com as Ciências da Comunicação e das Artes;

II -Conteúdos Específicos: estudos relacionados com a Administração, a Economia e o Direito, aplicados à Hotelaria, interligados com o Turismo, além de estudos sobre Sistemas de Comunicação e Informática, incluindo domínio de, pelo menos, uma língua estrangeira;

III -Conteúdos Teórico-Práticos: obtidos pelos sistemas informatizados, incluindo Laboratórios, com as diversas interligações em rede, cujos produtos sejam postos à disposição do fluxo turístico, observadas as peculiaridades do mercado hoteleiro, Estágio Curricular Supervisionado, Estágios Integradores, Atividade Extraclasse, Atividades de Pesquisa e de Iniciação Científica e Atividades Complementares. 
Anexo B - Sites de busca dos Cursos de Turismo

Site da Embratur
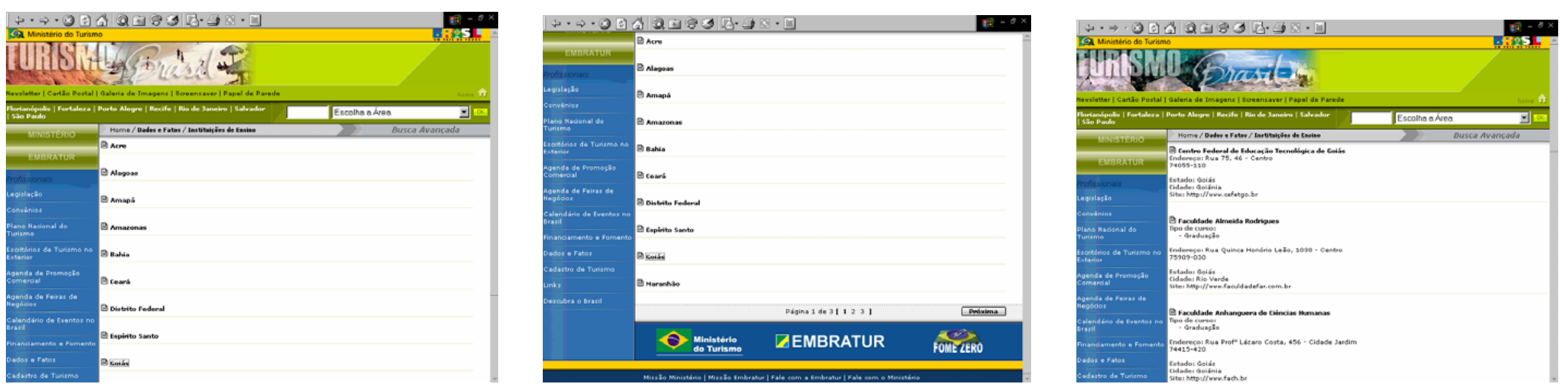

Site da ABBTUR
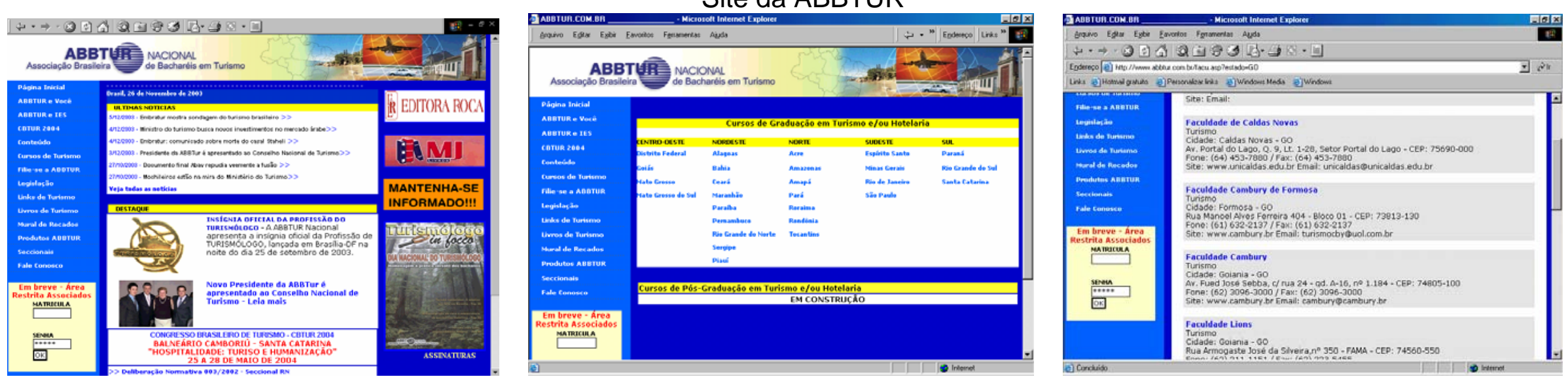
Site da CANALTUR

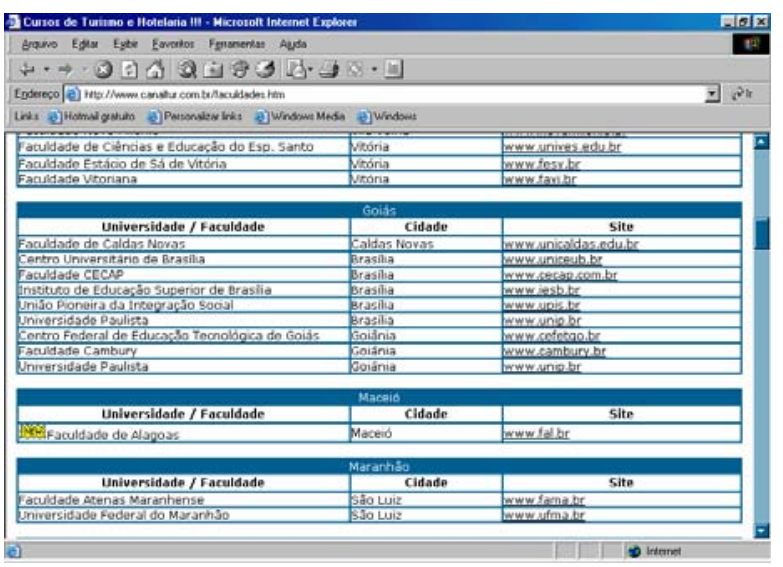

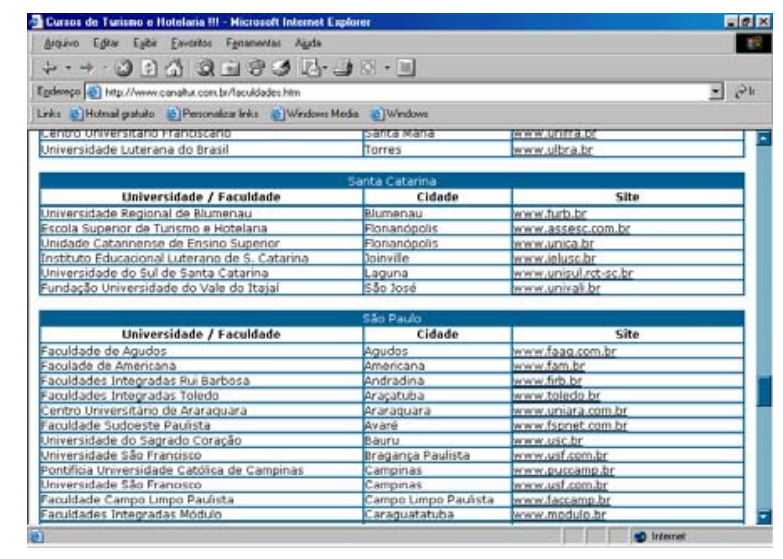

Site da TURISMOLOGIA

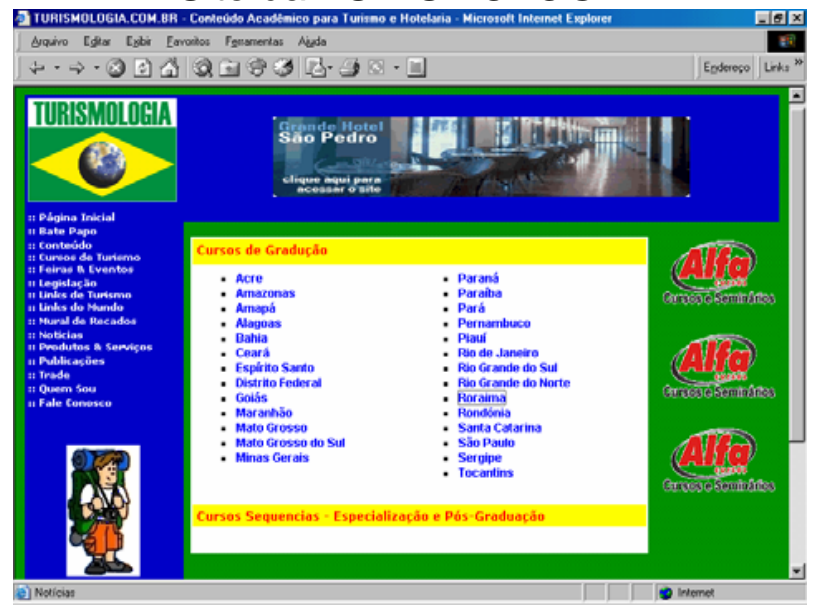




\section{Anexo C - IES que possuem Cursos de Turismo e Hotelaria}

\section{ACRE}

Faculdade de Ciências Jurídicas e Sociais Aplicadas Rio Branco Graduação em Turismo

Cidade: Rio Branco - AC

Site: www.firb.net

\section{ALAGOAS}

Fundação Alagoana de Amparo à Pesquisa e Cultura Tecnologia em Turismo

Cidade: Maceió - AL

Site: www.fapec.org.br

Faculdade de Alagoas

Graduação em Turismo

Cidade: Maceió - AL

Site: www.fal.br

Faculdade Alagoana de Administração

Graduação em Turismo

Cidade: Maceió - AL

Site:

Centro de Estudos Superiores de Maceió

Graduação em Turismo

Cidade: Maceió - AL

Site: www.fejal.com.br

Centro Federal de Educação Tecnológica de Alagoas

Graduação em Tecnologia em Turismo

Cidade: Maceió - AL

Site: www.cefet-al.br

\section{AMAPÁ}

Instituição de Ensino Superior do Amapá

Graduação em Turismo

Site: www.iesap-moderno.com.br
Associação Educacional da Amazônia

Graduação em Turismo

Cidade: Macapá - AP

Site: www.seama.edu.br

\section{AMAZONAS}

Instituto Metropolitano de Ensino

Graduação em Turismo

Cidade: Manaus - AM

Site: www.cemetronet.com.br

Universidade Paulista-AM

Graduação em Turismo

Cidade: Manaus - AM

Site: www.unip.br

Universidade do Estado do Amazonas

Graduação em Turismo

Cidade: Manaus - AM

Site: www.uea.edu.br

Centro Integrado de Ensino Superior do Amazonas

Graduação em Turismo

Cidade: Manaus - AM

Site: www.ciesa.br

Centro Universitário Luterano de Manaus

Graduação Turismo e Entretenimento

Cidade: Manaus - AM

Site: www.ulbra-mao.br

Centro Universitário Nilton Lins

Graduação em Turismo

Cidade: Manaus - AM

Site: www.niltonlins.br

\section{BAHIA}

Faculdade Santíssimo Sacramento

Graduação em Turismo

Cidade: Alagoinhas - BA

Site: www.fsssacramento.br

Faculdade de Tecnologia e Ciências - Feira de Santana Graduação em Turismo

Cidade: Feira de Santana - BA

Site: www.ftc.br

Faculdade de Guanambi

Graduação em Turismo

Cidade: Guanambi - BA

Site:

Faculdades Montenegro

Graduação em Turismo

Cidade: Ibicaraí - BA

Site: www.uol.com.br/aemontenegro

Faculdade de Ciências e Tecnologia - Itabuna

Graduação em Turismo

Cidade: Itabuna - BA

Site: www.ftc.br

Faculdade Baiana de Ciências

Graduação em Turismo

Cidade: Lauro de Freitas - BA

Site: www.unibahia.br

Faculdade UNIME de Ciências Sociais

Graduação em Turismo

Cidade: Lauro de Freitas - BA

Site: www.unime.com.br

Faculdade Sete de Setembro

Graduação em Turismo

Cidade: Paulo Afonso - BA

Site: www.fasete.com.br 
Faculdade Baiana de Ciências Contábeis Graduação em Turismo Cidade: Salvador - BA Site: www.fabac.com.br

Instituto Baiano de Ensino Superior Graduação em Turismo Cidade: Salvador - BA Site:

Faculdade Castro Alves Graduação em Turismo Cidade: Salvador - BA

Site: www.castroalves.b

Faculdades Integradas Olga Mettig Graduação em Turismo

Cidade: Salvador - BA

Site: www.famettig.br

Faculdades Jorge Amado

Graduação em Turismo

Cidade: Salvador - BA

Site: www.faculdadesjorgeamado.com.br

Faculdades Integradas da Bahia

Graduação em Turismo

Cidade: Salvador - BA

Site: www.fib.br

Universidade Salvador Graduação em Turismo Cidade: Salvador - BA Site: www.unifacs.br

Faculdade São Salvador

Graduação em Turismo

Cidade: Salvador - BA

Site: www.saosalvador.edu.br

Universidade do Estado da Bahia Graduação em Turismo

Cidade: Salvador - BA

Site: www.uneb.br
Fundação Visconde de Cairu

Graduação em Turismo

Cidade: Salvador - BA

Site: www.cairu.br

Faculdade Hélio Rocha

Graduação em Turismo

Cidade: Salvador - BA

Site: www.heliorocha.com.br

Faculdade de Tecnologia e Ciências - Salvador

Graduação em Turismo

Cidade: Salvador - BA

Site: www.ftc.br

Instituto de Educação Superior Unyahna

Graduação em Turismo

Cidade: Salvador - BA

Site: www.unyahna.br

Faculdades do Descobrimento

Graduação em Turismo

Cidade: Santa Cruz Cabrália - BA

Site: www.facdesco.com.br

Faculdade do Sul da Bahia

Graduação em Turismo

Cidade: Teixeira de Freitas - BA

Site:

Faculdade Zacarias de Góes

Graduação em Turismo

Cidade: Valença - BA

Site: www.fazag.com.br

Faculdade de Tecnologia e Ciências - Vitória da Conquista Graduação em Turismo

Cidade: Vitória da Conquista - BA

Site: www.ftc.br

CEARÁ

Faculdade Vale do Jaguaribe

Graduação em Turismo

Graduação em Tư

Site: www.fvj.br
Faculdade Evolutivo

Graduação em Turismo

Site: wimwevolu

com.br

Centro Federal de Educação Tecnológica do Ceará

Tecnologia em Turismo

Cidade: Fc

Site: www.cefetce.b

Universidade de Fortalez

Graduação em Turismo

Cidade. Fortaleza - CE

Site: www.unifoRuabr

Faculdade Integrada do Ceará

Graduação em Turismo

Cidade: Fortaleza - CE

Site: www.fic.br

Universidade Estadual do Ceará

Graduação em Turismo

Cidade: Fortaleza - CE

Site: www.iepro.org.br

DISTRITO FEDERAL

Faculdade CECAP

Graduação em Turismo

Cidade: Brasília - DF

Site: www.cecap.com.br

UPIS - Faculdades Integradas

Graduação em Turismo

Cidade: Brasília - DF

Site: www.upis.br

Faculdade Euro-Americana

Graduação em Turismo

Cidade: Brasília - DF

Site: www.euroamericana.com.b

Universidade Paulista UNIP

Graduação em Turismo

Cidade: Brasília - DF

Site: www.unip.br 
IESB- Instituto de Educação Superior de Brasília Graduação em Turismo

Cidade. Brasília - DF

Site: $\underline{w w w . i e s b . b r}$

Faculdade da Terra de Brasília - FTB

Graduação em Turismo com ênfase em Eco turismo

Cidade: Brasília - DF

Site: www.ftp.br

Associação Península Norte de Educação, Ciência e

Cultura - Faculdade CECAP do Largo Norte

Graduação em Turismo

Cidade: Brasília - DF

Site: www.cecap.com.br

UPIS - Faculdades INTEGRADAS

Graduação de Turismo

Cidade: Brasília - DF

Site: www.upis.br

Centro Universitário de Brasília - UNICEUB

Graduação em Turismo com ênfase em Empreendedorismo

Cidade: Brasília - DF

Site: www.ceub.br

Faculdades Caiçaras

Graduação em Turismo

Cidade: Brasília - DF

Site: www.facbraz.hpg.com.br

\section{ESPÍRITO SANTO}

Faculdades Integradas Padre Anchieta de Guarapari Graduação em Turismo

Cidade: Guarapari - ES

Site: www.fipag.br

Faculdade da Região Serrana

Graduação em Turismo

Cidade: Santa Maria de Jetibá - ES

Site: www.farese.com.br

Faculdade Vale do Cricaré

Graduação em Turismo

Cidade: São Mateus - ES

Site: www.ivc.br
Faculdade de Administração da Serra

Graduação em Turismo

Site: www.uniserra.br

Associação de Ensino Superior Unificado do Centro Leste Graduação em Turismo

Cidade: Serra - ES

Site: www.ucl.br

Faculdade Estácio de Sá de Vila Velha

Graduação em Turismo

Cidade: Vila Velha - ES

Site: $\underline{w w w . f e s v v . b r}$

Faculdade Novo Milênio

Graduação em Turismo

Cidade: Vila Velha - ES

Site: www.novomilenio.br

Centro Universitário Vila Velha

Graduação em Turismo

Cidade: Vila Velha - ES

Site: www.uvv-es.br

Faculdade Estácio de Sá de Vila Velha

Graduação em Turismo

Cidade: Vitória - ES

Site: www.fesv.br

Instituto de Ensino Superior e Formação Avançada de Vitória

Graduação em Turismo

Cidade: Vitória - ES

Site: www.favi.br

\section{GOIÁS}

Faculdade de Caldas Novas

Graduação em Turismo

Cidade: Caldas Novas - GO

Site: www.unicaldas.edu.br

Faculdade Cambury de Formosa

Graduação em Turismo

Cidade: Formosa - GO

Site: www.cambury.br
Faculdade Cambury

Graduação em Turismo

Cidade: Goiânia - GO

Site: www.cambury.br

Faculdade Lions

Graduação em Turismo

Cidade: Goiânia - GO

Site: www.unilions.org

Faculdade Padrão

Graduação em Turismo - Administração Hoteleira

Cidade: Goiânia - GO

Site: www.faculdadepadrao.com.br

Universidade Paulista-GO

Graduação em Turismo

Cidade: Goiânia - GO

Site: www.unip.br

Instituto Unificado de Ensino Superior Objetivo

Graduação em Turismo

Cidade: Goiânia - GO

Site: www.objetivo-goiania.br

Faculdades Alves Faria

Graduação em Turismo com ênfase em Hotelaria, Meio

Ambiente e Marketing.

Cidade: Goiânia - GO

Site: $\underline{w w w . a l f a . b r}$

Faculdade Anhanguera de Ciências Humanas

Graduação em Turismo

Cidade: Goiânia - GO

Site: www.fach.br

Centro Federal de Educaação Tecnológica de Goiás

Tecnologia em Turismo

Cidade: Goiânia - GO

Site: $\underline{w w w . c e f e t g o . b r}$

Instituto de Ensino Superior de Rio Verde

Graduação em Turismo

Cidade: Rio Verde - GO

Site: www.objetivo.rv.psx.org 
Faculdade Almeida Rodrigues

Graduação em Turismo

Site: www.faculdadefar.com.b

\section{MARANHÃO}

Faculdade Atenas Maranhense

Graduação em Turismo

Cidade: Imperatriz - MA

Site: www.fama.br

Faculdade de Imperatriz

Graduação em Turismo com ênfase em Planejamento

Turístico

Cidade: Imperatriz - MA

Site: www.facimp.edu.br

Unidade de Ensino Superior Dom Bosco

Graduação em Turismo

Cidade: São Luís - MA

Site: www.undb.edu.br

Universidade Federal do Maranhão

Graduação em Turismo

Cidade: São Luís - MA

Site: www ufma br

Faculdade São Luís

Graduação em Turismo

Cidade: São Luís - MA

Site: www.facsaoluis.br

Faculdade Atenas Maranhense

Graduação em Turismo

Cidade: São Luís - MA

Site: www.fama.br

Centro Universitário do Maranhão

Graduação em Turismo

Cidade: São Luís - MA

Site: www.ceuma.br

\section{MATO GROSSO}

Universidade do Estado de Mato Grosso

Graduação em Turismo

Cidade: Cáceres - MT

Site: www.unemat.br

Faculdade de Cuiabá

Graduação em Turismo

Cidade: Cuiabá - MT

Site: www.fauc.com.br

Faculdades Integradas Cândido Rondon Graduação em Turismo

Graduação em Turismo

Site: www.unirondon.br

Faculdade Afirmativo

Graduação em Turismo

Cidade: Cuiabá - MT

Site: www.afirmativo.com.br

Universidade do Estado de Mato Grosso Graduação em Turismo

Cidade: Nova Xavantina - MT

Site: www.unemat.br

Centro Superior de Rondonópolis

Graduação em Turismo

Cidade: Rondonópolis - MT

Site: www.cesur.br

Faculdade de Sinop

Graduação em Turismo

Cidade: Sinop - MT

Site: www.fasip.com.br

Centro Universitário de Várzea Grande

Graduação em Turismo

Cidade: Várzea Grande - M

Site: www.univag.com.br
MATO GROSSO DO SUL

Universidade Federal de Mato Grosso do Su

Graduação em Turismo

Cidade: Aquidauana - MS

Site: www.ufms.br

Instituto de Ensino Superior da FUNLEC de Bonito

Graduação em Turismo

Cidade: Bonito - MS

Site:

Instituto de Ensino Superior da FUNLEC

Graduação em Turismo

Cidade: Campo Grande - MS

Site: www.funlec.com.br

Universidade para o Desenvolvimento do Estado e da

Região do Pantanal

Grad. em Turismo c/ ênfase em Hotelaria e/ou Turismo Ambiental

Cidade: Campo Grande - MS

Site: www.uniderp.br

Faculdade Estácio de Sá de Campo Grande

Graduação em Turismo

Cidade: Campo Grande - MS

Site: www.fes.br

Universidade Católica Dom Bosco

Graduação em Turismo

Cidade: Campo Grande - MS

Site: www.ucdb.br

Faculdades Integradas de Cassilândia

Graduação em Turismo

Cidade: Cassilândia - MS

Site: www.ficms.com.br

Instituto de Ensino Superior do Pantana

Graduação em Turismo

Cidade: Corumbá - MS

Site: www.pantanalnet.com.br/iespan

Faculdades Integradas de Coxim

Graduação em Turismo

Cidade: Coxim - MS

Site: 
Centro Universitário da Grande Dourados

Graduação em Turismo

Cidade:

Site: www.unigran.br

Universidade Estadual do Mato Grosso do Sul

Graduação em Turismo

Cidade: Dourados - MS

Site: www.uems.br

Universidade Estadual de Mato Grosso do Sul

Graduação em Turismo com ênfase em ambientes naturais

Cidade: Jardim - MS

Site: www.uems.br

Faculdade de Turismo de Nova Andradina

Graduação em Turismo

Cidade: Nova Andradina - MS

Site: www.alphams.com.br/finan

Faculdade de Selvíria

Graduação em Turismo

Cidade: Selvíria - MS

Site: www.faculdadeselviria.com.br

Faculdades Integradas de Três Lagoas

Graduação em Turismo

Cidade: Três Lagoas - MS

Site: www.aems.com.br

\section{MINAS GERAIS}

Centro de Estudos Superiores Aprendiz

Graduação em Turismo

Cidade: Barbacena - MG

Site: www.aprendiz.edu.br

Universidade Presidente Antônio Carlos

Graduação em Turismo

Cidade: Barbacena - MG

Site: www.unipac.br

União de Negócios e Administração

Graduação em Turismo

Cidade: Belo Horizonte - MG

Site: www.una.br
Centro Universitário Newton Paiva

Graduação em Turismo

Cidade. Belo Horizonte - MG

Site: www.newtonpaiva.b

Faculdade de Estudos Administrativos

Graduação em Turismo

Cidade: Belo Horizonte - MG

Site: www.fead.br

Instituto Belo Horizonte de Ensino Superior

Graduação em Turismo

Cidade: Belo Horizonte - MG

Site: www.unip.br

Universidade Católica de Minas Gerais

Graduação em Turismo

Cidade: Belo Horizonte - MG

Site: www.pucminas.br

Centro Universitário de Belo Horizonte

Graduação em Turismo

Cidade: Belo Horizonte - MG

Site: www.unibh.br

Faculdade Estácio de Sá

Graduação em Turismo

Cidade: Belo Horizonte - MG

Site: www.bh.estacio.br

Instituto de Geociências - Campus Pampulha

Graduação em Turismo

Cidade: Belo Horizonte - MG

Site: www.igc.ufmg.br

Fundação Mineira de Educação e Cultura - FUMEC

Graduação em Turismo

Cidade: Belo Horizonte - MG

Site: www.fumec.br

Fac. de Filosofia, Ciências e Letras Nossa Senhora do Sion - UEMG

Graduação em Turismo

Cidade: Campanha - MG

Site: $\underline{w w w . f c c p . b r}$
Faculdade de Turismo de Carating

Graduação em Turismo

ade: Caratinga - MG

Site:

Universidade do Vale do Rio Verde de Três Corações UNINCOR

Graduação em Turismo

Cidade: Caxambu - MG

Site: www.unincoRuabr

Faculdade Santa Rita

Graduação em Turismo

Cidade: Conselheiro Lafaiete - MG

Site: www.fasaRuacom.br

Unileste Universidade

Graduação em Turismo

Site: www.unilestemg.br

Fundação Educacional Comunitária Formiguense

Graduação em Turismo

Cidade: Formiga - MG

Site: www.fuom.br

Universidade Vale do Rio Doce - Univale

Graduação em Turismo

Cidade: Governador Valadares - MG

Site: www.univale.br

Faculdade Regional do Vale do Aço - FARV / UNIPAC

Graduação em Turismo

Cidade: Ipatinga - MG

Site: www.farv.com.br

Fundação Comunitária de Ensino Superior de Itabira -

FUNCESI

Graduação em Turismo

Cidade: Itabira - MG

Site: www.funcesi.br

Escola Superior de Ciências Contábeis e Administrativas de Ituiutaba - ESCCAI

Graduação em Turismo

Site: Iumu esccai - Mom 
Universidade Federal de Juiz de Fora

Graduação em Turismo

Cidade: Juiz de Fora - MG

Site: $\underline{w w w . u f j f . b r}$

Faculdade Estácio de Sá de Juiz de Fora

Graduação em Turismo

Cidade: Juiz de Fora - MG

Site: www.fesjf.estacio.br

Universidade Presidente Antônio Carlos - UNIPAC Graduação em Turismo

Cidade: Juiz de Fora - MG

Site: www.unipac.br

Faculdade Presbiteriana Gammon

Graduação em Turismo com ênfase em Ecoturismo

Cidade: Lavras - MG

Site: www.gammon.br

Faculdade Pitágoras de Montes Claros

Graduação em Turismo

Cidade: Montes Claros - MG

Site: www.fap-moc.com.br

Universidade Federal de Ouro Preto

Graduação em Turismo

Cidade: Ouro Preto - MG

Site: www.ufop.br

PUC - Poços de Caldas

Graduação em Turismo

Cidade: Poços de Caldas - MG

Site: www.pucpcaldas.br

Universidade do Vale do Sapucaí

Graduação em Turismo

Cidade: Pouso Alegre - MG

Site: www.univas.edu.br

Centro de Ensino Superior de Santa Luzia - CESAL

Graduação em Turismo

Cidade: Santa Luzia - MG

Site: www.facsal.br
Faculdade de Turismo de Santos Dumont

Graduação em Turismo

Cidade: Santos Dumont - MG

Site: www.jfshop.com.br/factursd

Instituto Presidente Tancredo de Almeida Neves - IPTAN

Graduação em Turismo

Cidade: São João Del Rei - MG

Site: www.iptan.edu.br

Faculdade Santa Marta

Graduação em Turismo e Hotelaria

Cidade: São Lourenço - MG

Site: www.faculdadesantamarta.br

Faculdade Promove de sete Lagoas

Graduação em Turismo

Cidade: Sete Lagoes - MG

Site: www.faculdadepromove.b

Faculdade Cenecista de Sete Lagoas

Graduação em Turismo

Cidade: Sete Lagoas - MG

Site: www.fcsl.edu.br

Universidade de Uberaba

Graduação em Turismo

Cidade: Uberaba - MG

Site: www.uniube.br

Centro Universitário do Triângulo

Graduação em Turismo

Cidade: Uberlândia - MG

Site: www.unitmg.com.br

\section{PARÁ}

Universidade Federal do Pará

Graduação em Turismo

Cidade: Belém - PA

Site: www.ufpa.br

Instituto Esperança de Ensino Superior

Graduação em Turismo

Cidade: Santarém - PA

Site: www.iespes.edu.br
PARAÍBA

Faculdade de Ciências Sociais Aplicadas

Graduação em Turismo

Cidade: Campina Grande - PB

Site: www cesed br

Faculdade de Ciências Sociais e Aplicadas

Graduação em Turismo

Cidade: Campina Grande - PB

Site: www.facisa.edu.br

Universidade Federal da Paraíba

Graduação em Turismo

Cidade: João Pessoa - PB

Site: www.ufpb.br

Instituto de Educação Superior de João Pessoa

Graduação em Turismo

Cidade: João Pessoa - PB

Site: www.iesp.edu.br

Faculdades Aspe

Graduação em Turismo

Cidade: João Pessoa - PB

Site: www.asper.com.br

\section{PARANÁ}

Universidade Estadual do Paraná - Campus FECEA

Graduação em Turismo

Cidade: Apucarana - PR

Site: www.fecea.br

Faculdade de Apucarana

Graduação em Turismo e Hotelaria

Cidade: Apucarana - PR

Site: www.fap.com.br

Faculdade Estadual de Ciências e Letras de Campo Mourão

Graduação em Turismo

Cidade: Campo Mourão - PR

Site: www.fecilcam.br 
Centro Integrado de Ensino Superior

Graduação em Turismo

Cidade. Campo Mourão - PR

Site: www.grupointegrado.br

Universidade Paranaense

Graduação em Turismo e Hotelaria

Cidade: Cascavel - PR

Site: /www.unipaRuabr

Faculdade Cristo Rei

Graduação em Turismo

Cidade: Cornélio Procópio - PR

Site: www.faccrei.com.br

Faculdade Educacional de Cornélio Procópio

Graduação em Turismo

Cidade: Cornélio Procópio - PR

Site: $\underline{w w w . f e c o p . c o m . b r}$

Faculdade Organização Paranaense de Ensino Técnico Graduação em Turismo

Cidade: Curitiba - PR

Site: www.opet.com.b

Faculdades do Brasil

Graduação em Turismo

Cidade: Curitiba - PR

Site: www.unibrasil.com.br

Universidade Tuiuti do Paraná

Graduação em Turismo (Hotelaria)

Cidade: Curitiba - PR

Site: www.utp.br

Faculdades Hoyler

Graduação em Turismo

Cidade: Curitiba - PR

Site: www.hoyler.edu.br

Faculdades Integradas de Curitiba

Graduação em Turismo

Cidade: Curitiba - PR

Site: www.aena.br
Centro Universitário Positivo

Graduação em Turismo

Cidade: Curitiba - PR

Site: www.unicenp.br

Faculdades Integradas Santa Cruz de Curitiba

Graduação em Turismo

Cidade: Curitiba - PR

Site: www.santacruz.br

Universidade Federal do Paraná

Graduação em Turismo

Cidade: Curitiba - PR

Site: www.ufpr.br

Pontifícia Universidade Católica do Paraná

Graduação em Turismo

Cidade: Curitiba - PR

Site: www.pucpr.br

Unidade de Ensino Superior Expoente

Graduação em Turismo

Cidade: Curitiba - PR

Site: www.uniexp.edu.br

Centro Universitário Campos de Andrade

Graduação em Turismo

Site: www.uniandrade.br

Faculdade Internacional de Curitiba

Graduação em Turismo

Cidade: Curitiba - PR

Site: www.facinter.br

Instituto de Ensino Superior de Foz do Iguaçu

Graduação em Turismo

Cidade: Foz do Iguaçu - PR

Site: www.cesufoz.edu.br

Universidade Estadual do Oeste do Paraná

Graduação em Hotelaria

Cidade: Foz do Iguaç - PR

Site: www.unioeste.br
Universidade Estadual do Oeste do Paraná

Graduação em Turismo

dade: Foz do Iguaçu - PR

Site: www.foz.unioeste.br

Faculdade Dinâmica das Cataratas

Graduação em Turismo

Cidade: Foz do Iguaçu - PR

Site: www.udc.br

Faculdades Unificadas de Foz do Iguaçu

Tecnologia em Hotelaria

Cidade: Foz do Iguaçu - PR

Site: www.unifoz.com.br

Faculdades Guarapuava

Graduação em Turismo

Cidade: Guarapuava - PR

Site: www.faculdadesguarapuava.b

Faculdade Dinâmica

Graduação em Turismo

Cidade: Jacarezinho - PR

Site: www.fanorpi.com.br

FAEL - Faculdade da Lapa

Graduação em Turismo e Hotelaria

Cidade: Lapa - PR

Site:

Universidade Norte do Paraná

Graduação em Turismo com ênfase em Hotelaria Cidade: Londrina - PR

Site: www.unopar.br

Centro Universitário Filadélfia

Graduação em Turismo

Cidade: Londrina - PR

Site: www.unifil.br

Faculdade Nobel

Graduação em Turismo

Cidade: Maringá - PR

Site: www.nobel.br 
Centro Universitário de Maringá

Graduação em Turismo

Cidade: Maringá - PR

Site: www.cesumar.br

Universidade Paranaense - UNIPAR

Graduação em Turismo e Hotelaria

Cidade: Paranavaí - PR

Site: www.unipaRuabr

Faculdade Mater Dei

Graduação em Turismo

Cidade: Pato Branco - PR

Site: www.colegiomaterdei.com.br

Faculdades Santa Amélia

Graduação em Turismo

Cidade: Ponta Grossa - PR

Site: www.uniandrade.br

Universidade Estadual de Ponta Grossa

Graduação em Turismo

Cidade: Ponta Grossa - PR

Site: www.uepg.br

Faculdade Metropolitana de Curitiba

Graduação em Turismo

Cidade: São José dos Pinhais - PR

Site: www.famec.com.br

Faculdade de Ensino Superior de São Miguel do Iguaçu Graduação em Turismo

Cidade: São Miguel do Iguaçu - PR

Site: www.faesi.com.br

Faculdade Sul Brasil

Graduação em Turismo com ênfase em eventos

Cidade: Toledo - PR

Site: www.fasul.com.br

Universidade Paranaense

Graduação em Turismo e Hotelaria

Graduação em Turismo e

Site: www.unipar.br
Fundação Faculdade da Cidade de União da Vitória Graduação em Turismo

Cidade: União da Vitória - PR

Site: www.face.br

\section{PERNAMBUCO}

Faculdade do Vale do Ipojuca

Graduação em Turismo

Cidade: Caruaru - PE

Site: www.favip.edu.br

Faculdade da Escada

Graduação em Turismo

Graduação em Turismo

Site:

Faculdade Metropolitana da Grande Recife

Graduação em Turismo

Cidade: Jabotão dos Guararapes - PE

Site:

Faculdade de Comunicação e Turismo de Olinda

Graduação em Turismo

Cidade: Olinda - PE

Site: www.apesu.br/facotur

Faculdade de Ciências Humanas de Olinda

Graduação em Turismo com ênfase em Meio Ambiente

Ecoturismo

Cidade: Olinda - PE

Site: www facho br

Escola Superior de Marketing

Graduação em Turismo

Cidade: Recife - PE

Site: $\underline{w w w . f a c u l d a d e f a m a . c o m . b r}$

Universidade Católica de Pernambuco

Graduação em Turismo

Cidade: Recife - PE

Site: www.unicap.br

Universidade Federal de Pernambuco

Graduação em Hotelaria

Cidade: Recife - PE

Site: http://rec.web.terra.com.br/hoteltur
Faculdade Metropolitana do Grande Recife Graduação em Turismo

Cidade: Recife - PE

Site:

Universidade Federal de Pernambuco

Graduação em Turismo

Cidade: Recife - PE

Site: http://rec.web.terra.com.br/hoteltur

Faculdade Santa Helena

Graduação em Turismo

Cidade: Recife - PE

Site: www.fash.com.br

Instituto Pernambucano de Ensino Superio

Graduação em Turismo

Cidade: Recife - PE

Site: www.objetivo.br/ipesu

Faculdade Salesiana do Nordeste

Graduação em Turismo

Cidade: Recife - PE

Site: www.salesianorecife.com.br

Faculdade Integrada do Recife

Graduação em Turismo

Cidade: Recife - PE

Site: $w w w . f i r . b r$

Faculdade Integrada de Pernambuco

Graduação em Turismo

Cidade: Recife - PE

Site: www.facipe.edu.b

Centro de Ensino Superior de Pernambuco

Graduação em Turismo

Cidade: Recife - PE

Site: www.facipe.edu.br

Faculdade de Filosofia do Recife

Graduação em Turismo

Cidade: Recife - PE

Site: www.fafire.br 
Faculdade Escritor Osman da Costa Lins

Graduação em Turismo

Cidade: Vitória de Santo Antão - PE

Site: www.avecfacol.edu.b

Faculdades Integradas da Vitória de Santo Antão Graduação em Turismo

Cidade: Vitória de Santo Antão - PE

Site: www.faintvisa.com.br

\section{PIAUÍ}

Faculdade Mafrense de Turismo e Ciências Humanas de Teresina

Graduação em Turismo

Cidade: Teresina - PI

Site:

Faculdade São Judas Tadeu

Graduação em Turismo

Cidade: Teresina - PI

Site: www.fsjt.com.br

Faculdade das Atividades Empresariais de Teresina

Graduação em Turismo

Cidade: Teresina - PI

Site: www.faete.edu.br

Associação de Ensino Superior do Piauí

Graduação em Turismo

Cidade: Teresina - PI

Site: $\underline{w w w . a e s p i . b r}$

\section{RIO DE JANEIRO}

Centro Universitário de Barra Mansa

Graduação em Turismo

Cidade: Barra Mansa - RJ

Site: www.ubm.br

Universidade Veiga de Almeida - Campus III

Graduação em Turismo

Cidade: Cabo Frio - RJ

Site: www.uva.br
Universidade Estácio de Sá

Graduação em Turismo

Cidade: Macaé - RJ

Site: www.estacio.br

Centro Universitário Plínio Leite

Graduação em Turismo

Cidade: Niterói - RJ

Site: www.plinioleite.com.br

Universidade Estácio de Sá - UNESA - Campus Friburgo Graduação em Turismo

Cidade: Nova Friburgo - RJ

Site: www.estacio.br

Universidade Católica de Petrópolis

Graduação em Turismo

Cidade: Petrópolis - RJ

Site: www.ucp.br

Universidade Estácio de Sá - Campus Petrópolis

Graduação em Turismo

Cidade: Petrópolis - RJ

Site: www.estacio.br

Universidade Estácio de Sá - Campus Copacabana

Graduação em Turismo

Cidade: Rio de Janeiro - RJ

Site: www.estacio.br

Universidade Veiga de Almeida

Graduação em Turismo

Cidade: Rio de Janeiro - RJ

Site: www.uva.br

Faculdades São José

Graduação em Turismo

Cidade: Rio de Janeiro - RJ

Site: www.saojose.br

Faculdades Integradas Hélio Alonso

Graduação em Turismo e Hotelaria

Cidade: Rio de Janeiro - RJ

Site: www.facha.br
Centro Universitário da Cidade

Graduação em Turismo

Cidade: Rio de Janeiro - RJ

Site: www.univercidade.br

Faculdade Machado de Assis

Graduação em Turismo

Cidade: Rio de Janeiro - RJ

Site: www.famanet.br

Centro Universitário da Cidade - Campus Lagoa

Graduação em Turismo

Cidade: Rio de Janeiro - RJ

Site: www.univercidade.com.edu

Universidade Estácio de Sá - Campus Estácio

Graduação em Turismo

Cidade: Rio de Janeiro - RJ

Site: www.estacio.br

Faculdade Paraíso

Graduação em Turismo

Cidade: Rio de Janeiro - RJ

Site: www.faculdadesparaiso.com.br

Universidade Estácio de Sá - Campus Ilha do Governador

Graduação em Turismo

Cidade: Rio de Janeiro - RJ

Site: www.estacio.br

Universidade Estácio de Sá - Campus Barra

Graduação em Turismo

Cidade: Rio de Janeiro - RJ

Site: www.estacio.br

Universidade Estácio de Sá - Campus Centro

Graduação em Turismo

Cidade: Rio de Janeiro - RJ

Site: $\underline{w w w . e s t a c i o . b r}$

Universidade Estácio de Sá - Campus Barra II

Graduação em Turismo

Site: www.estacio.br 
Universidade Estácio de Sá - Campus Copacabana Graduação em Turismo

aneiro - RJ

Site: www.estacio.br

Universidade Veiga de Almeida- Campus II - Barra Graduação em Turismo

Cidade: Rio de Janeiro - RJ

Site: www.uva.br

Universidade Castelo Branco

Graduação em Turismo

Cidade: Rio de Janeiro - RJ

Site: www.castelobranco.br

Faculdades Integradas de Jacarepaguá

Graduação em Turismo

Cidade: Rio de Janeiro - RJ

Site: www.fij.br

Faculdade Paraíso

Graduação em Turismo

Cidade: São Gonçalo - RJ

Site: www.faculdadeparaiso.com.br

\section{RIO GRANDE DO NORTE}

Universidade Potiguar - UNP

Cidade: Natal - RN

Site: www.unp.br

Universidade Federal do Rio Grande do Norte

Graduação em Turismo

Cidade: Natal - RN

Site: www.ufrn.br

Faculdade de Ciências, Cultura e Extensão do Rio Grande do Norte

Graduação em Turismo

Cidade: Natal - RN

Site: www.facex.com.br
RIO GRANDE DO SUL

Universidade Luterana do Brasil

Graduação em Turismo

Cidade: Canoas - RS

Site: www.ulbra.br

Universidade de Caxias do Su

Graduação em Turismo

Cidade: Caxias do Sul - RS

Site: www.ucs.b

Universidade de Cruz Alta

Graduação em Turismo

Cidade: Cruz Alta - RS

Site: www.unicruz.edu.br

Centro de Ensino Superior de Farroupilha

Graduação em Turismo

Cidade: Farroupilha - RS

Site:

Centro Universitário Feevale

Graduação em Turismo

Cidade: Novo Hamburgo - RS

Site: www.feevale.br

Fundação Universidade Federal de Pelotas

Graduação em Turismo

Graduação em Turis

Site: www.ufpel.tche.br

Faculdades Rio-grandenses

Graduação em Turismo

Cidade: Porto Alegre - RS

Site: www.fargs.br

Pontifícia Universidade Católica do Rio Grande do Sul

Graduação em Turismo

Cidade: Porto Alegre - RS

Site: www.pucrs.br

Instituto Porto Alegre da Igreja Metodista

Graduação em Turismo com ênfase em Hotelaria

Cidade: Porto Alegre - RS

Site: www.ipametodista.edu.br
Universidade de Santa Cruz do Sul

Graduação em Turismo

Cidade: Santa Cruz do Sul - RS

Site: www.unisc.br

Centro Universitário Franciscano

Graduação em Turismo

Cidade: Santa Maria - RS

Site: www.unifra.br

Faculdades de Taquara

Graduação em Turismo

Cidade: Taquara - RS

Site: www.faccat.br

RONDÔNIA

Faculdade de Ciências Humanas, Exatas e Letras de

Graduação em Turismo

Cidade: Porto Velho - RO

Site: www.inter-net.com.br/faro

Centro de Ensino Faculdade São Lucas

Graduação em Turismo

Cidade: Porto Velho - RO

Site:

\section{SANTA CATARINA}

Universidade do Vale do Itajaí

Graduação em Turismo e Hotelaria

Cidade: Balneário Camboriú - SC

Site:

Universidade Regional de Blumenau

Graduação em Turismo e Lazer

Cidade: Blumenau - SC

Site: www.furb.br

Instituto Blumenauense de Ensino Superior

Graduação em Turismo

Cidade: Blumenau - SC

Site: www unibes com br 
Fundação Educacional de Brusque

Tecnologia em Turismo

Cidade: Brusque - SC

Site: www.febe.edu.br

Universidade do Contestado

Graduação em Turismo

Cidade: Caçador - SC

Site: www.unc.br

Universidade do Sul de Santa Catarina

Graduação em Turismo

Cidade: Florianópolis - SC

Site: www.unisul.br

Centro de Educação Superior

Graduação em Turismo

Cidade: Florianópolis - SC

Site: www.unica.br

Associação de Ensino de Santa Catarina

Graduação em Turismo

Cidade: Florianópolis - SC

Site: www.assesc.com.br

Associação Educacional Leonardo da Vinci

Graduação em Turismo

Cidade: Indaial - SC

Site: www asselvi.com.br

Instituto Cenecista Fayal de Ensino Superior

Graduação em Turismo

Cidade: Itajaí - SC

Site: www.fayal.com.br

Instituto Superior e Centro Educacional Luterano Bom Jesus

Graduação em Turismo

Cidade: Joinvile - SC

Site: www.ielusc.br

Faculdade Cenecista de Joinville

Graduação em Turismo

Cidade: Joinville - SC

Site: www.fcj.com.br
Faculdade Sinergia

Graduação em Turismo

Cidade. Navegantes - SC

Site: www.sinergia.edu.br

Universidade para o Desenvolvimento do Alto Vale do Itajal Turismo - ênfase em meio ambiente e Turismo - ênfase em

eventos

Cidade: Rio do Sul - SC

Site: www.unidavi.edu.br

Universidade Vale do Itajaí

Graduação em Turismo e Hotelaria

Cidade: São José - SC

Site: www.univali.br

Instituto de Ensino Superior da Grande Florianópolis

Graduação em Turismo

Cidade: São José - SC

Site: www.ies.edu.br

Faculdade Estácio de Sá de Santa Catarina

Graduação em Turismo

Cidade: São José - SC

Site: www.sc.estacio.br

Universidade do Sul de Santa Catarina

Graduação em Turismo

Cidade: Tubarão - SC

Site: www.unisul.br

Faculdade de Ciências Sociais Aplicadas

Graduação em Turismo

Cidade: Xaxim - SC

Site: $\underline{\text { www.celer.com.br }}$

\section{SÃO PAULO}

Faculdade SENAC de Turismo e Hotelaria de Águas de São Pedro Graduação em Tecnologia em Turismo

Cidade: Águas de São Pedro - SP

Site: www.sp.senac.br
Faculdade SENAC de Turismo e Hotelaria de Águas de São Pedro

Graduação em Turismo - Ecoturismo

Cidade: Águas de São Pedro - SP

Site: www.sp.senac.br

Faculdade de Agudos

Graduação em Turismo

Cidade: Agudos - SP

Site:

Faculdade de Americana

Graduacão em Turismo

Cidade: Americana - SP

Site: www.fam.br

Instituto de Ensino Superior de Americana

Graduação em Turismo

Cidade. Americana - SP

Site: www.iesam.edu.b

Centro Universitário Salesiano de São Paulo

Graduação em Turismo

Cidade: Americana - SP

Site: www.unisal.br

Faculdades Integradas "Rui Barbosa"

Graduação em Turismo com ênfase em Planejamento

Turístico

Cidade: Andradina - SP

Site: $\underline{w w w . f i r b . b r}$

Faculdades Integradas Toledo

Graduação em Turismo

Cidade: Araçatuba - SP

Site: $\underline{w w w . t o l e d o . b r}$

Faculdade da Fundação Educacional Araçatuba

Graduação em Turismo

Cidade: Araçatuba - SP

Site: www.feata.edu.br

Faculdade deTurismo da UNIP

Graduação em Turismo

Cidade: Araraquara - SP

Site: www.unip.br 
Centro Universitário de Araraquara

Graduação em Turismo

Site: www.uniara.com.br

Centro Universitário Hermínio Ometto

Graduação em Turismo

Cidade: Araras - SP

Site: www.uniararas.br

Faculdade de Arujá

Graduação em Turismo

Cidade: Arujá - SP

Site: $\underline{w w w . f a c u l d a d e i e s a . c o m . b r}$

Faculdade de Turismo da UNIP

Graduação em Turismo

Cidade: Assis - SP

Site: www.unip.br

Faculdade de Ciências Sociais e Aplicadas do Vale da Jurumirim

Graduação em Turismo

Cidade: Avaré - SP

Site: www.eduvaleavare.com.br

Faculdade Sudoeste Paulista

Graduação em Turismo e Hotelaria

Cidade: Avaré - SP

Site: www.fspnet.com.br

Faculdade do Interior Paulista

Graduação em Turismo

Cidade: Barra Bonita - SP

Site: www.funbbe.br

Universidade do Sagrado Coração

Graduação em Turismo

Cidade: Bauru - SP

Site: reitoria@usc.br

Faculdades Integradas de Bauru

Graduação em Turismo

Site: www.fibbauru.br
Faculdade Bertioga

Graduação em Turismo - Hotelaria e Eventos

Cidade: Bertioga - SP

Site: $\underline{w w w . f a c u l d a d e s p i r a t i n i n g a . e d u . b r}$

Faculdades Integradas de Botucatu

Graduação em Turismo

Cidade: Botucatu - SP

Site: www.unifac.com.br

Universidade São Francisco

Graduação em Turismo

Cidade: Bragança Paulista - SP

Site: www.saofrancisco.edu.br

Universidade Paulista -Campinas

Graduação em Turismo

Cidade: Campinas - SP

Site: www.unip.br

Pontifícia Universidade Católica de Campinas

Graduação em Turismo

Cidade: Campinas - SP

Site: www.puc-campinas.com.br

Faculdade SENAC de Turismo e Hotelaria de Campos do

Jordão

Graduação em Turismo

Cidade: Campos do Jordão - SP

Site: www.sp.senac.br

Faculdades Integradas Módulo

Graduação em Tecnologia em Turismo e Hospitalidade

Cidade: Caraguatatuba - SP

Site: www.modulo.br

Faculdade Casa Branca

Graduação em Turismo

Cidade: Casa Branca - SP

Site: www.facab.br

Faculdade Associada de Cotia

Graduação em Turismo

Cidade: Cotia - SP

Site: www.faac.br
Faculdade Diadema

Graduação em Turismo

Cidade: Diadema - SP

Site: www.fadnet.br

Faculdade de Ciências Gerenciais de Dracena

Graduação em Turismo

Cidade: Dracena - SP

Site: www.cesd.br

Centro Regional Universitário de Espírito Santo do Pinhal -

CREUPI

Graduação em Turismo

Cidade: Espírito Santo do Pinhal - SP

Site: www.creupi.br

Universidade Camilo Castelo Branco

Graduação em Turismo

Cidade: Fernandópolis - SP

Site: www.unicastelo.b

Universidade de Franca

Graduação em Turismo

Cidade: Franca - SP

Site: www.unifran.br

Associação Cultural e Educacional de Garça

Graduação em Turismo

Cidade: Garça - SP

Site: $\underline{w w w . f a e f . b r}$

Universidade Metodista de São Paulo - campus Guaratinguetá

Graduação em Turismo

Cidade: Guaratinguetá - SP

Site: www.metodista.br

Faculdade Adélia Camargo Corrêa

Graduação em Turismo

Cidade: Guarujá - SP

Site: www.faculdadedoguaruja.com.br

Instituto Delta de Educação e Pesquisa

Graduação em Turismo

Site: mumidepe edu b 
Universidade Guarulhos

Graduação em Turismo

Cidade: Guarulhos - SP

Site: www.ung.br

Faculdade Hoyle

Graduação em Turismo

Cidade: Hortolândia - SP

Site: www.instituto-hoyler.br

Faculdade de Filosofia, Ciências e Letras de Ibitinga

Graduação em Turismo

Cidade: Ibitinga - SP

Site: www.faibi.com.br

Faculdade de Educação e Ciências Gerenciais de Indaiatuba

Graduação em Turismo

Cidade: Indaiatuba - SP

Site: www.unopec.com.br

Faculdade de Ciências Gerenciais

Graduação em Turismo

Cidade: Itanhaém - SP

Site: $\underline{w w w . f c g i t a . c o m . b r}$

nstituto Itapetiningano de Ensino Superio

Graduação em Turismo

Cidade: Itapetininga - SP

Site: www.ebras.com.br/iies

Instituto de Ensino Superior de Itapira

Graduação em Turismo

Site: www.iesiunip.hpg.ig.com.b

Faculdade de Ciências Contábeis e Administrativas de Itararé

Graduação em Turismo

Cidade: Itararé - SP

Site: www.fafitfacic.com.br

Centro Universitário Nossa Senhora do Patrocínio

Graduação em Turismo

Cidade: Itú - SP

Site: www.ceunsp.br
Faculdade de Jaguariúna

Graduação em Turismo

Cidade: Jaguariúna - SP

Site: www.unianhanguera.edu.br

Faculdades Integradas de Jales

Graduação em Turismo

Cidade: Jales - SP

Site: $\underline{w w w . f a c u l d a d e s j a l e s . c o m . b}$

Faculdade de Turismo da UNIP

Graduação em Turismo

Cidade: Jundiaí - SP

Site: www.unip.br

Faculdade de Turismo da UNIP

Graduação em Turismo

Cidade: Limeira - SP

Site: www.unip.br

Instituto Superior de Ciências Aplicadas

Graduação em Turismo

Cidade: Limeira - SP

Site: www.alie.b

Universidade Metodista de Piracicaba - Campus de Lins

Graduação em Turismo

Cidade: Lins - SP

Site: www.unimep.br

Centro Universitário Salesiano de São Paulo

Graduação em Turismo

Cidade: Lorena - SP

Site: www.unisal.br

Universidade de Marília

Graduação em Turismo

Cidade: Marília - SP

Site: www.unimar.br

Universidade Braz Cubas

Graduação em Turismo

Cidade: Moji das Cruzes - SP

Site: www.brazcubas.br
Centro Universitário Fieo

Graduação em Turismo

Cidade: Osasco - SP

Site: www.unifieo.br

Faculdade Integração da Zona Oeste

Graduação em Turismo

Cidade: Osasco - SP

Site: www.fizo.com.br

Universidade Bandeirante de São Paulo

Graduação em Turismo

Cidade: Osasco - SP

Site:

Faculdade Fernão Dias

Graduação em Turismo

Cidade: Osasco - SP

Site: www.fernaodiaspais.com.br

Faculdades Integradas de Ourinhos

Graduação em Turismo

Cidade: Ourinhos - SP

Site: www.fio.edu.br

Faculdade Estácio de Sá de Ourinhos

Graduação em Turismo

Cidade: Ourinhos - SP

Site: www.ourinhos.estacio.br

Faculdade de Ciências Gerenciais

Graduação em Turismo

Cidade: Paraguaçu Paulista - SP

Site: www.funge.com.br

Universidade Metodista de Piracicaba

Graduação em Turismo

Cidade: Piracicaba - SP

Site: www.unimep.br

Faculdade de Presidente Epitácio

Graduação em Turismo

Cidade: Presidente Epitácio - SP

Site: www.cespe.com.br 
Universidade do Oeste Paulista Graduação em Turismo

Prudente - SP Site: www.unoeste.br

Instituto de Ensino Superior $\mathrm{COC}$

Graduação em Turismo

Cidade: Ribeirão Preto - SP

Site: www.faculdadescoc.com.br

Universidade de Ribeirão Preto

Graduação em Turismo com ênfase em Hotelaria

Cidade: Ribeirão Preto - SP

Site: www.unaerp.br

Faculdade de Turismo da UNIP

Graduação em Turismo

Cidade: Ribeirão Preto - SP

Site: www.unip.br

Centro Universitário Barão de Mauá - UFBM

Graduação em Turismo

Cidade: Ribeirão Preto - SP

Site: www.baraodemaua br

Faculdades Bandeirantes

Graduação em Turismo

Cidade: Ribeirão Preto - SP

Site: www.faban.com.br

Centro Universitário Moura Lacerda

Graduação em Turismo

Cidade: Ribeirão Preto - SP

Site: $\underline{w w w . m o u r a l a c e r d a . c o m . b r}$

Centro Universitário Barão de Mauá

Graduação em Turismo

Cidade: Ribeirão Preto - SP

Site: www baraodemaua br

Faculdade Santana de Salto

Graduação em Turismo

Cidade: Salto - SP

Site:
Faculdades Integradas de Santa Fé do Sul

Graduação em Turismo

Cidade: Santa Fé do Sul - SP

Site: www.funecfisa.br

Faculdades Integradas Teresa D'ávila-Santo André

Graduação em Turismo

Cidade: Santo André - SP

Site: www.salesianas.com.br

Fefisa Faculdades Integradas

Graduação em Turismo

Cidade: Santo André - SP

Universidade do Grande ABC

Graduação em Turismo

Cidade: Santo André - SP

Site: www.uniabc.br

Faculdade Octógono

Graduação em Turismo

Cidade: Santo André - SP

Site: www.foco.br

Centro Universitário Monte Serrat

Graduação em Turismo

Cidade: Santos - SP

Site: www.unimonte.br

Faculdade de Turismo da UNIP

Graduação em Turismo

Cidade: Santos - SP

Site: www.unip.br

Universidade Metodista de São Paulo

Graduação em Turismo

Cidade: São Bernardo do Campo - SP

Site: www.metodista.br

Universidade Bandeirante de São Paulo

Graduação em Turismo

Cidade: São Bernardo do Campo - SP

Site: www.uniban.br
Faculdade Anchieta

Graduação em Turismo

Cidade: São Bernardo do Campo - SP

Site: www.faculdadeanchieta.com.br

Faculdade Editora Naciona

Graduação em Turismo

Cidade: São Caetano do Sul - SP

Site: www.faenac.edu.br

Centro Universitário Central Paulista

Graduação em Turismo - Ênfase em Ecoturismo

Cidade: São Carlos - SP

Site: www.unicep.com.br

Faculdade de Turismo da UNIP

Graduação em Turismo

Cidade: São José do Rio Pardo - SP

Site: www.unip;br

União das Faculdades dos Grandes Lagos

Graduação em Turismo

Cidade: São Jose do Rio Preto - SP

Site: www.unilago.com.br

Centro Universitário de Rio Preto

Graduação - Gestão em Hotelaria

Cidade: São José do Rio Preto - SP

Site: www.unirpnet.com.br

Centro Universitário do Norte Paulista

Graduação em Turismo - Tecnologia em Hotelaria e

Eventos

Cidade: São José do Rio Preto - SP

Site: www.unorp.br

Universidade Paulista - São José dos Campos

Graduação em Turismo

Cidade: São José dos Campos - SP

Site: www.unip.br

Universidade do Vale do Paraíba

Graduação em Turismo

Cidade: São José dos Campos - SP

Site: www.univap.br 
Faculdade Marechal Rondon

Graduação em Turismo

Site: $\underline{w w w . u n i n o v e . b r / p r o s e l f m R u a h t m}$

Universidade São Judas Tadeu

Graduação em Turismo

Cidade: São Paulo - SP

Site: www.saojudas.br

Faculdades Integradas de São Paulo

Graduação em Turismo

Cidade: São Paulo - SP

Site: $\underline{w w w . f i s p . b r}$

Faculdades Integradas Rio Branco

Graduação em Turismo

Cidade: São Paulo - SP

Site: www.riobrancofac.edu.br

Faculdades Integradas Teresa Martin

Graduação em Turismo

Cidade: São Paulo - SP

Site: www.fatema.b

Faculdades Oswaldo Cruz

Graduação em Turismo - Eventos e Lazer

Cidade: São Paulo - SP

Site: www.oswaldocruz.br

Pontifícia Universidade Católica de São Paulo

Graduação em Turismo

Cidade: São Paulo - SP

Site: www.pucsp.br

Universidade Anhembi Morumbi

Graduação em Turismo

Cidade: São Paulo - SP

Site: www.anhembi.b

Universidade Bandeirante de São Paulo

Graduação em Turismo

Cidade: São Paulo - SP

Site: www.uniban.br
Universidade Cidade de São Paulo

Graduação em Turismo

Cidade: São Paulo - SP

Site: www.unicid.br

Universidade Cruzeiro do Sul

Graduação em Turismo

Cidade: São Paulo - SP

Site: www.unicsul.br

Universidade de Santo Amaro

Graduação em Turismo

Cidade: São Paulo - SP

Site: www.unisa.br

Universidade Ibirapuera

Graduação em Turismo

Cidade: São Paulo - SP

Site: $\underline{w w w . i b i r a p u e r a . b r}$

Faculdades Integradas Cantareira

Graduação em Turismo

Cidade: São Paulo - SP

Site: www.cantareira.br

Universidade São Marcos

Graduação em Turismo

Cidade: São Paulo - SP

Site: www.smarcos.br

Universidade Bandeirante de São Paulo

Graduação em Turismo

Cidade: São Paulo - SP

Site: www.uniban.br

Faculdade de Turismo da UNIP - Alphaville

Graduação em Turismo

Cidade: São Paulo - SP

Site: www.unip.br

Faculdade de Turismo da UNIP - Anália Franco

Graduação em Turismo

Cidade: São Paulo - SP

Site: www.unip.br
Faculdade de Turismo da UNIP - Anchieta

Graduação em Turismo

Site: www.unip.br

Faculdade de Turismo da UNIP - Marg Pinheiros

Graduação em Turismo

Cidade: São Paulo - SP

Site: www.unip.br

Faculdade de Turismo da UNIP - Marques

Graduação em Turismo

Cidade: São Paulo - SP

Site: www.unip.br

Faculdade de Turismo da UNIP - Paulista

Graduação em Turismo

Cidade: São Paulo - SP

Site: www.unip.br

Faculdade de Turismo da UNIP - Paz

Graduação em Turismo

Cidade: São Paulo - SP

Site: www.unip.br

Faculdade de Turismo da UNIP - Santana

Graduação em Turismo

Cidade: São Paulo - SP

Site: www.unip.br

Universidade de São Paulo

Graduação em Turismo

Cidade: São Paulo - SP

Site: www.usp.br

Faculdade Albert Einstein de São Paulo

Graduação em Turismo

Cidade: São Paulo - SP

Site: www.faesp.com.br

Faculdade de Turismo da UNIP - Tatuapé

Graduação em Turismo

Cidade: São Paulo - SP

Site: www.unip.br 
Centro de Educação Tecnológica em Hotelaria

Tecnologia em Hotelaria

Cidade: São Paulo - SP

Site:

Centro de Educação Tecnológica Interamericano

Tecnologia em Turismo de Eventos

Cidade: São Paulo - SP

Site: www.ceinter.com.br

Centro Federal de Educação Tecnológica de São Paulo

Tecnologia em Turismo

Cidade: São Paulo - SP

Site: www.cefetsp.br

Centro Universitário Assunção

Graduação em Turismo

Site: www.fai.br

Centro Universitário Belas Artes

Graduação em Turismo

Cidade: São Paulo - SP

Site: www.belasartes.br

Centro Universitário Capital

Graduação em Turismo

Cidade: São Paulo - SP

Site: www.unicapital.edu.br

Centro Universitário das Faculdades Metropolitanas Unidas - UNIFMU

Graduação em Turismo

Cidade: São Paulo - SP

Site: www.fmu.br

Centro Universitário Ibero-Americano

Graduação em Turismo
Cidade: São Paulo - SP

Site: www.ibero.br

Faculdades Integradas Interamericanas

Graduação em Turismo

de: São Paulo - SP

Site: www.faiter.com.br
Centro Universitário Sant'anna

Graduação em Turismo

Cidade:

Site: www.santanna.br

Faculdade SENAC de Turismo e Hotelaria de São Paulo

Tecnologia em Turismo

Cidade: São Paulo - SP

Site: www.sp.senac.br

Faculdade de Educação e Ciências Gerenciais de São Paulo

Graduação em Turismo

Cidade: São Paulo - SP

Site: www.opec.com.br

Faculdade Santa Rita

Graduação em Turismo

Cidade: São Paulo - SP

Site: www.santarita.br

Faculdade Piratininga

Graduação em Turismo

Cidade: São Paulo - SP

Site: www.faculdadespiratininga.edu.br

Faculdade Magister

Graduação em Turismo

Cidade: São Paulo - SP

Site: www.magister.edu.br

Faculdade Interlagos de Educação e Cultura

Graduação em Turismo

Cidade: São Paulo - SP

Site: www.fac-interlagos.b

Faculdade Independente Butantã

Graduação em Turismo

Cidade: São Paulo - SP

Site: www.fibutanta.br

Centro Universitário Nove de Julho

Graduação em Turismo

Cidade: São Paulo - SP

Site: www.uninove.br
Faculdade de Educação e Cultura Montessori

Graduação em Turismo

Site: www.montessorinet.com.br

Faculdade de Ciências Humanas de São Paulo

Graduação em Turismo

Cidade: São Paulo - SP

Site: $\underline{w w w . f e s p . b r}$

Faculdade Brasília de São Paulo

Graduação em Turismo

Cidade: São Paulo - SP

Site: www.brasiliasp.br

Faculdade Associada Brasi

Graduação em Turismo

Cidade: São Paulo - SP

Site: www.faculdadebrasil.edu.br

Faculdade Integração

Graduação em Turismo

Cidade: São Vicente - SP

Site: www.faculdadeintegracao.com.br

Universidade de Sorocaba

Graduação em Turismo

Cidade: Sorocaba - SP

Site: www.uniso.br

Faculdade de Educação e Ciências Gerenciais de Sumaré

Graduação em Turismo

Cidade: Sumaré - SP

Site: www.unopec.com.br

Faculdade Taboão da Serra

Graduação em Turismo

Cidade: Taboão da Serra - SP

Site: $\underline{w w w . f t s . c o m} . b r$

Instituto Taubaté de Ensino Superior

Graduação em Turismo

Cidade: Taubaté - SP

Site: 
Universidade de Taubaté

Administração com habilitação em Hotelaria e Turismo

Cidade: Ubatuba - SP

Site: www.unitau.br

Faculdade de Vinhedo

Graduação em Turismo

Cidade: Vinhedo - SP

Site: www.faculdadedevinhedo.com.br

Centro Universitário de Votuporanga

Graduação em Turismo

Cidade: Votuporanga - SP

Site: $\underline{w w w . f e v . e d u . b r}$
SERGIPE

Instituto Sergipe de Ensino Superio

Graduação em Turismo

Cidade: Aracaju - SE

Site: www.unip.br

Universidade Tiradentes

Graduação em Turismo

Cidade: Aracaju - SE

Site: www.unit.br
TOCANTINS

Instituto de Ensino Superior Objetivo - IEPO

Graduação em Turismo - Ênfase em Hotelaria e Eventos

Cidade: Palmas - TO

Site: www.objetivo-tocantins.b

Centro Universitário Luterano de Palmas

Graduação em Turismo

Cidade: Palmas - TO

Site: www.ulbra-to.b 


\section{Anexo D - Artigo: A importância das visitas técnicas no curso de turismo e hotelaria}

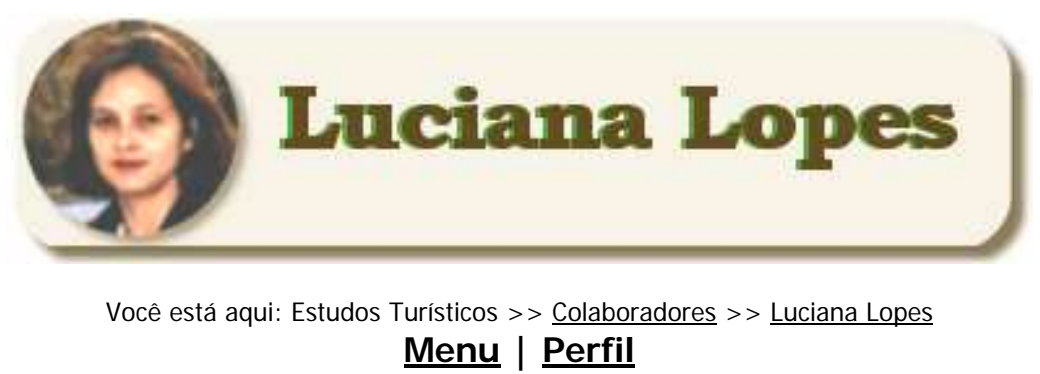

Luciana Marques Lopes é professora no curso de Turismo da Faculdade Santa Marta em São Lourenço, MG, sócia-gerente da Agência de Viagem Oficina de Turismo de São Lourenço e Caxambu, MG e mestranda em Educação pela Universidade Vale Rio Verde, Três Corações, MG.

$\bar{A}$ importância das visitas técnicas no curso de turismo e hotelaria

7/9/2003 - Luciana Marques Lopes

Uma das técnicas de ensino nos cursos de turismo de extrema importância são as visitas técnicas , pois através delas, o aluno alia a teoria e prática. É notável como os alunos absorvem muito mais o que aprendeu e compartilham com os colegas seu aprendizado e experiência.

Percebe-se hoje, no ensino superior, a ausência da motivação pelo estudo, pela pesquisa, enfim, pelo aprendizado, fato que as instituições e a maioria dos professores procuram contornar com as novas tecnologias educacionais e metodologias de trabalho.

Segundo pesquisa publicada na Revista Ensino Superior edição 45/2003, verifica-se que:

Os estudantes desejam planos de estudos que tenham aplicação prática em seu trabalho, com conteúdos que contribuam para seu êxito profissional. Em relação aos professores, desejam aqueles que realmente estejam atuando e não aplicando teorias ultrapassadas.

Desejam uma educação eficiente e aprender o que necessitam aprender.

Desejam uma estrutura de ensino que possa maximizar a aprendizagem e não planos curriculares adaptados.

No segmento do turismo, a preocupação em aprimorar o processo ensino/aprendizagem, tem sido um dos desafios dos educadores nos cursos de graduação em turismo e hotelaria, haja vista, as constantes mudanças na economia e também na sociedade.

A formação de um profissional que atuará no setor de turismo é bastante complexa e multidisciplinar, visto que o curso abrange diversos conhecimentos na área de : Administração, Historia, Geografia, Cultura geral, dentre outros.

Uma das técnicas de ensino nos cursos de turismo de extrema importância são as visitas técnicas , pois através delas, o aluno alia a teoria e prática. Disciplinas como : Meios de Hospedagem , Agenciamento, Transportes, Geografia, História, podem utilizar deste recurso para aperfeiçoar o ensino - aprendizagem.

É notável como os alunos absorvem muito mais o que aprendeu e compartilham com os colegas seu aprendizado e experiência.

De uma maneira interdisciplinar, os professores precisam estar inteirados e trabalharem conjuntamente para o melhor aproveitamento do ensino.

As visitas técnicas, aplicadas de maneira correta e produtiva certamente contribuirá para o melhor desempenho dos alunos, fazendo com que eles possam vivenciar e entender o mercado em que estão inseridos e tornar-se profissionais conscientes e atentos para a realidade atual. 